\title{
Central Sites and the Development of Rural Settlements from the Middle to Late La Tène Period in Central Moravia
}

\author{
Centrální místa a vývoj osídlení ve střední a pozdní době laténské \\ na území střední Moravy
}

Ivan Čižmáŕ - Alžběta Danielisová

Redakci předloženo v ř́jnu 2020, upravená verze v únoru 2021

\begin{abstract}
At a certain point in time, there were two central places in central Moravia: an older unfortified central agglomeration near the present-day village of Němčice nad Hanou and a younger oppidum at Staré Hradisko. Each of this centres had its own approach to raw materials, orientation of the socio-economic contacts, and possibly political focus as well. Nermčice, being located at one of the main branches of the Amber Road, connected the Middle Danube area from the Mediterranean to the Adriatic; Stare Hradisko eventually expanded these contacts into a systematic trade network, being under the strong influence of the Bohemian region with links to Bavaria. During the LT C2, in addition to the location of the central place, changes took place in terms of material culture and settlement strategies in the region. This was further accentuated in LT D1 by the shift of settlements towards the west, to the vicinity of the oppidum and, at the same time, vacation of the corridor around the Morava River. In an attempt to chronologically assess the settlement pattern, it became evident how important it is to define, as precisely as possible, the dating of individual sites. This was only possible thanks to the detailed and extensive study of the material available (Čižmár̆ 2018). Thanks to precise dating of settlements and classification based on the new chronology, the seemingly illogical group of settlements in central Moravia revealed a distinct settlement network which, in particular during the period contemporary with the oppidum, allows us to see the significant changes in the number of sites and in the orientation of long-distance contacts that were possibly associated with historical events.
\end{abstract}

Middle and late La Tène period, settlement pattern, central places, agglomerations, oppidum, rural settlements, settlement shift

V oblasti střední Moravy a širšího okolí existovaly postupně dvě centrální lokality - starší neopevněná centrální aglomerace u Němčic nad Hanou a mladší oppidum Staré Hradisko. Každé z těchto center bylo ekonomicky a pravděpodobně i politicky orientováno jiným směrem - Němčice spojovala jantarová stezka se středním Podunajím a adriatickou oblastí, Staré Hradisko pak tyto kontakty rozvinulo $v$ systematickou obchodní sít s tím, že bylo patrně silně ovlivněno českým prostředím s vazbou na Bavorsko. Během stupně LT C2, společně se změnou centrálních lokalit, je evidentní také změna hmotných inventářủ jakož i sídelní strategie v nejbližším okolí center, která byla nějakou dobu současná. Tyto změny byly později zdůrazněny zejména během fáze LT D1, kdy došlo k větší koncentraci lokalit $v$ západní části sledovaného regionu s prostorovou vazbou na oppidum, a zároveň $k$ uprázdnění koridoru kolem řeky Moravy. Právě při snaze oddělit od sebe sídelní areály př́slušející $k$ danému zázemí se ukázalo, jak je důležité definovat co možná nejpřesněji chronologické zařazení jednotlivých lokalit, čehož bylo možné dosáhnout pouze na základě podrobného studia dostupného materiálu (Čižmár̆ 2018). Díky chronologickému rozdělení jednotlivých sídlišt do skupin se z doposud neprehledného seskupení sídlištních lokalit podařilo rozpoznat strukturu osídlení, na základě které je možné především v pozdní době laténské sledovat jak výrazný úbytek sídlištních poloh, tak i změnu v orientaci dálkových kontaktů a průběhu obchodních tras, které lze pravděpodobně spojovat s historickými událostmi.

Střední a pozdní doba laténská, sídelní struktura, centrální místa, aglomerace, oppidum, zemědělská sídliště, přesun osídlení

\section{Introduction}

The material culture of the middle and late La Tène period in central Moravia (Fig. 1) was strongly influenced by the presence of a central agglomeration near the present-day Němčice nad Hanou and its substantial influence over the surrounding settlements. The finds from the site allow for its dating to LT B2 - LT C2 (i.e. third to second century $\mathrm{BC}$ ), with the greatest development of specialised production and trade attributed to LT C1-C2 (i.e. 250-120 BC; cf. Čižmář - Kolníková - Noeske 2008, 664). Occasional finds from the most recent surveys show that some activities must be anticipated to have taken place during LT B1 and LT D1 too. Culturally, the agglomeration and the settlements in its surroundings were connected to the Middle Danube area. Long-distance contacts evidenced by the Mediterranean coins from Egypt, Carthage or Syracuse connected Němčice with northern Italy and were probably related to the newly founded trading site of Aquileia in the Adriatic (Kysela 2017). 

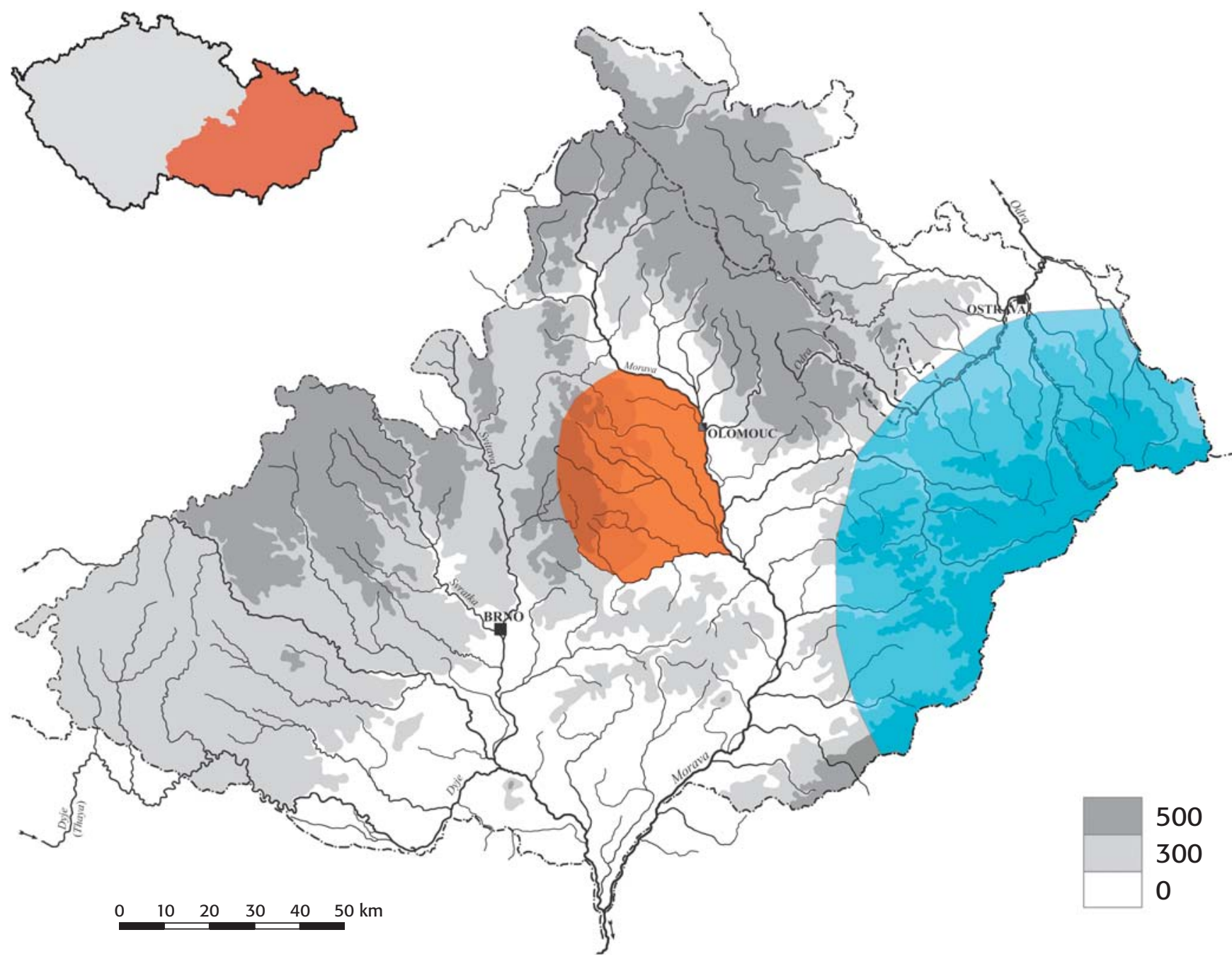

Fig. 1. Map of Moravia with the study area (red), and region of the Púchov culture (blue). Author I. Čižmár. - Obr. 1. Mapa Moravy s vyznačením sledovaného regionu (červeně) a území púchovské kultury (modře). Autor l. Čižmár̆.

Towards the end of LT C2 the oppidum of Staré Hradisko was founded. With it, an influx of cultural traits common in Bohemia appeared. New settlements were being founded in locations yet unsettled and, to a lesser extent, other settlements continued in the original locations. Specialised production and long-distance contacts would now take place at the oppidum and the other settlements would only rarely yield evidence of said activities. Situated along communication routes there are occasional finds, such as hoards (e.g. Ptení, cf. Čižmár̆ 2002b). The occupation of the oppidum seems to have ended at the end of LT D1b (ca. middle of the first century $\mathrm{BC}$ ) and the same appears to be the case of settlements in the region. No La Tène site younger than LT Dlb is documented from central Moravia so far.

Dating of rural settlements is sometimes difficult because of the partial temporal overlap of the two central sites. It is evident, that the development of the central agglomeration at Němčice peaked during LT C2 (two generations, roughly between 180-120 BC), whereas the (later) foundation of the oppidum at Stare Hradisko can be attributed to the same phase (i.e. either slightly before or around the middle of the second century $\mathrm{BC}$ ), i.e. about one generation before the end of Němčice. The continuity of both sites in terms of social, economic or political strategies has not yet been thoroughly investigated. Therefore, the purpose of this study includes an attempt to offer a chronological classification of all recorded settlements and by relating them to either of the central agglomeration to try and model the settlement structure in the region in connection with the development in the wider area of the Middle Danube.

Most of the results presented here are based on the dissertation of Ivan Čižmář (Čižmář 2018). These results, with the exception of single outputs (Čižmár̆ 2012a; 2015; Čižmář - Čižmář - Režný 2015; Čižmář - Hlubek 2016; Čižmář - Hlava - Šmíd 2005; Ženožičková - Nohálová - Vaněček 2016 etc.) have not yet been published in full detail. The author's extensive observations are based on detailed processing and dating of all settlement material from the region. The aim was mainly to elaborate the distinction of the material culture of the middle and late La Tène; thus the phases of LT B2-C2 (so-called 'Němčice horizon') and LT C2-D1 (so-called 'Staré Hradisko horizon'), respectively. 

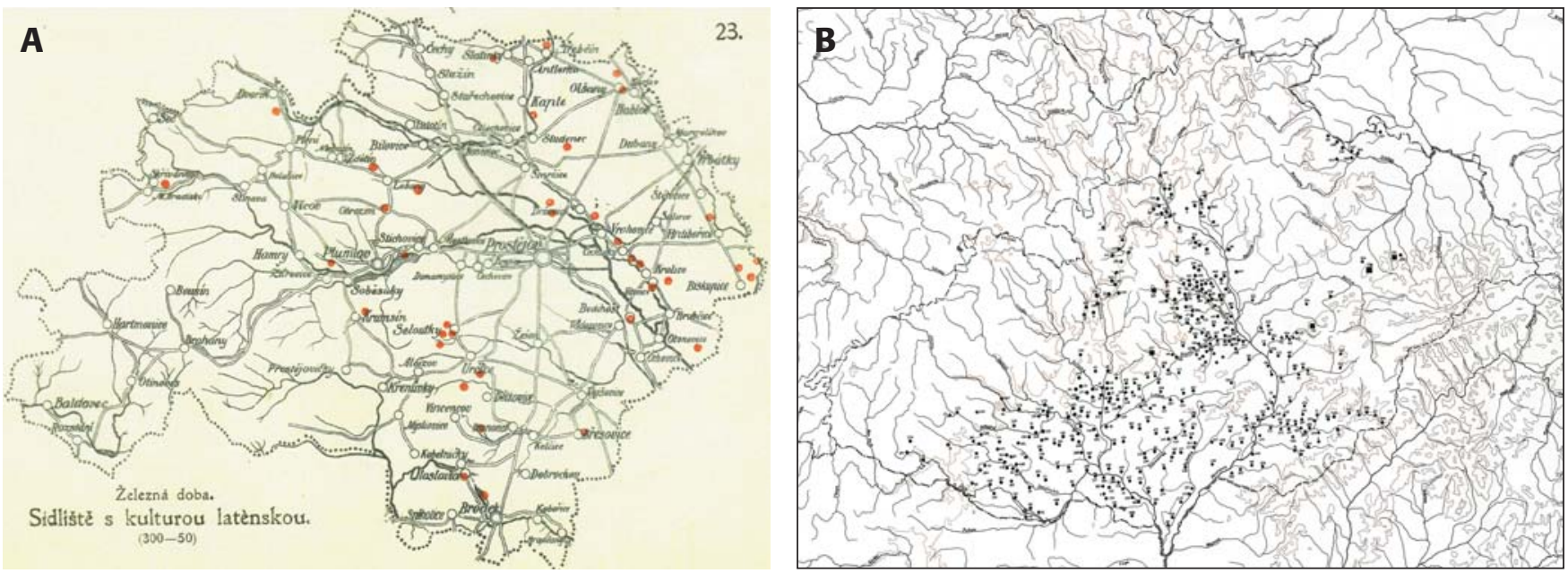

Fig. 2. Development of state of knowledge of La Tène settlement in Moravia: A. - A. Gottwald (1924). B. - J. Meduna (1980a). - Obr. 2. Vývoj stavu poznání laténského osídlení na Moravě: A. - A. Gottwald (1924). B. - J. Meduna (1980a).

\section{Methodology}

The main heuristic part consisted of the collection of information on the settlements in the region known from the literature. The basis of the data was collected from the catalogue of settlements in Moravia created by J. Meduna (1980b) based to a large extent on the list by E. Šimek (1958), with added information from 'Encyklopedie Keltů na Moravě' (Čižmářová 2004). Original sources were revised - especially in the case of works by $A$. Gottwald $(1924 ; 1931)$. Another key source of data was a list of sites by J. Šrot (1975) and later by D. Šiška (1996) which allowed for localisation of a part of earlier sites. The list of sites had been a subject of regular updates up until 2017, especially by data from the current literature ('Přehled výzkumů' and other; Fig. 2). Next, all the available museum collections were researched and evaluated critically. The basic criterion for the study of settlements is the chronological evaluation of material from surface surveys or rescue excavations. ${ }^{1}$ As a re-

\footnotetext{
${ }^{1}$ In this region, the analyses included collections from the mu seum in Prostějov which keeps a large part of finds made by A. Gottwald and available part of collection from the projects conducted by D. Šiška. Also kept here is more recent material from research projects carried out by the Prostějov branch of ÚAPP Brno (Institute for Archaeological Heritage), and smaller collections from projects by employees of the museum, as well as other researchers. A somewhat different situation was in the museum in Olomouc which also keeps part of the collection by A. Gottwald, finds from research projects by the museum and employees of Archeologické centrum Olomouc as well as material from older surveys carried out by the Prostějov branch of ÚAPP Brno. The condition of these collections did not allow for unlimited access. In this case we had to rely on the material in the catalogue by $J$. Meduna (1980b) and finds not listed there were studied in the museum. Other material from various sites in the southern part of the region was studied in the museum in Vyškov, some finds are kept in the museum in Kojetín, where a detailed list of La Tène material published by M. Hlava (2002b) was used for referrence. Numerous finds, especially those from the eastern parts of the region, are kept in the museum of Přerov; smaller collection of older finds from some sites is kept in the Moravian $\mathrm{Mu}$ seum in Brno; material from more recent projects organised by M. Čižmář was also evaluated.
}

sult, a comprehensive catalogue of sites was created. It included two classes of sites labelled as "UNVERIFIED" and "NOT LOCALISED"; while they must be respected and recorded for the sake of the integrity of sources, they will not be used in the analysis of the settlement structure.

Our primary goal was to revise the material from La Tène sites in the region and attempt to come up with the correct chronological assessment. It was not an easy task, as most finds from the settlements were ceramic fragments whose dating is only possible on a general scale, i.e. either middle or late La Tène period. First of all, such sites were excluded which contained exclusively early La Tène finds (i.e. LT A); only assemblages dated to LT B - LT D were included in the database; their chronology was established where applicable. The database of sites for the period and area in question comprised 170 entries (Fig. 3 and Appendix, pp. 228-231).

\subsection{Classification of sites in the studied area}

The entire La Tène material from the area was reviewed and classified chronologically. It was quite a complicated task, as the ceramics generally has certain limitations regarding chronological sensitivity. Individual relative phases of the La Tène period identifiable by the pottery lasted more than 100 years (Čižmár 2002a, 57), which means that in the case of long-term settlements, we may deal with more chronological phases, during which the site could have changed its location, even over greater distances. This may be one of the reasons why larger settlements ('agglomerations') seem to show different locations possibly inhabited by a similar number of people (Smrž 1994; Venclová 2001). The basic set of sites was divided into six groups based on chronology (Tab. 1) and typology (Tab. 2) of finds:

A1: settlements founded during the late La Tène period (the end of LT C2 - LT D1) as new locations. Only material from end LT C2 and LT D1 must be present; this type of sites can be referred to as 'Staré Hradisko horizon'. 

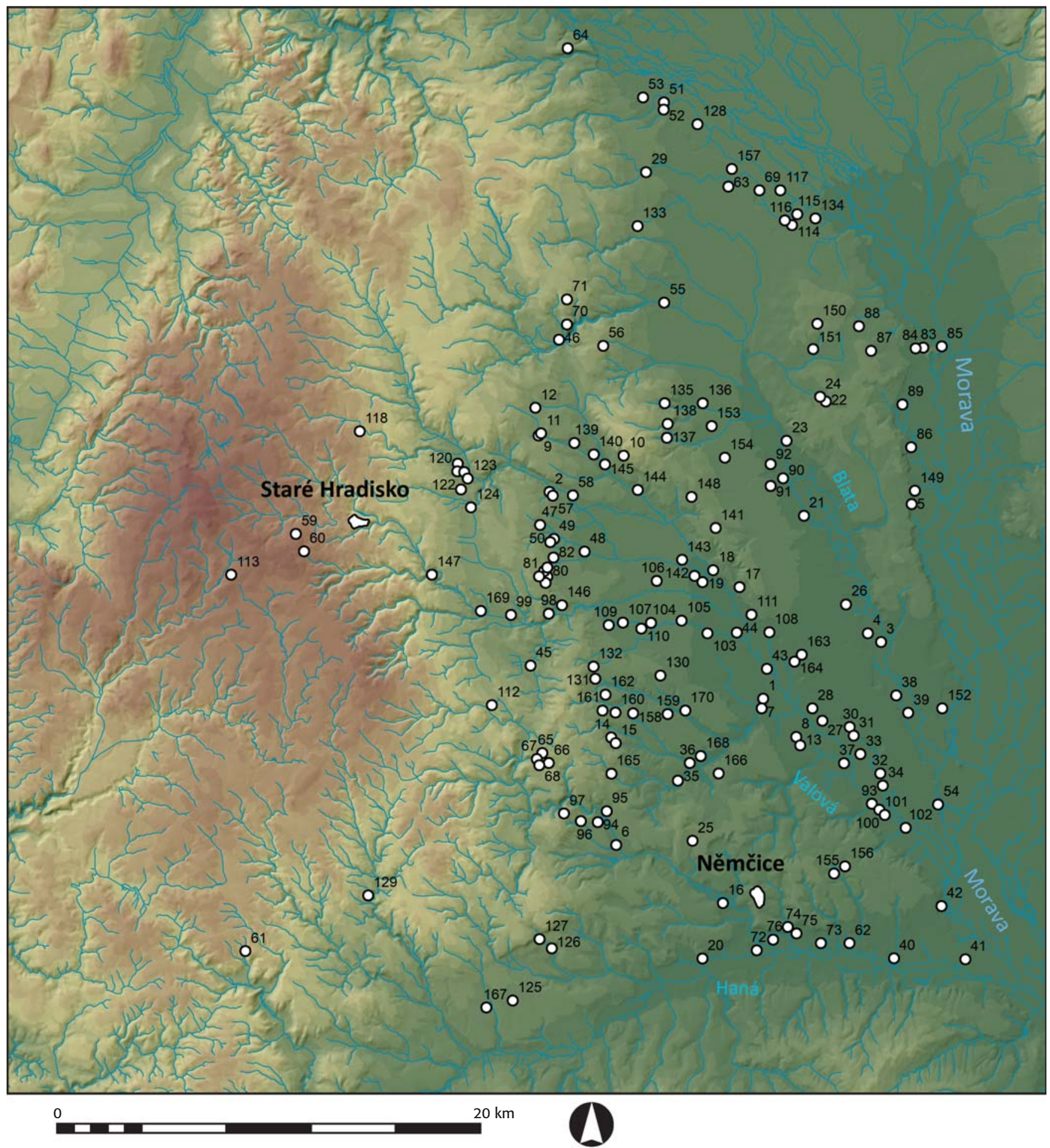

Fig. 3. The current state of knowledge of the middle to late La Tène period settlement in central Moravia. Site numbers correspond to the sequence in the Appendix (data by I. Čižmář, author A. Danielisová). - Obr. 3. Současný stav poznání středo až pozdně laténského osídlení na střední Moravě. Čísla lokalit odpovídají pořadí v príloze (data I. Čižmárí, autor A. Danielisová).

A2: settlements existing during the oppidum period (LT C2 - LT D1) with older material being present in the assemblage (LT B-C1, LT C2). Therefore, the site was contemporaneous with Němčice, but also continued to the oppidum period.

B1: settlements where younger material was found but it is not time-sensitive enough to allow its dating as LT D1 exclusively. These sites can include settlements which existed together with the Němčice agglomeration or the Staré Hradisko oppidum. It can also be a settlement founded as a new location, but no clear evidence exists.

B2: as $\mathrm{B} 1$, but including also the older finds dating to LT B-C1.

C: settlements existing in the middle La Tène period (LT B2-C2) with no signs of continuity to the later pe- 


\begin{tabular}{|l|l|}
\hline \multicolumn{2}{|l|}{ CHRONOLOGY: groups according to dating } \\
\hline A1 & late La Tène (specifically the end of LT C2 - LT D1) - new settlements \\
\hline A2 & continuity from middle (LT B2-C1) to late (LT C2-D1) La Tène \\
\hline B1 & LT C2 (without LT B-C1) - possibility of continuity to LT C2-D1 \\
\hline B2 & LT B2-C2 - possibility of continuity to LT C2-D1 \\
\hline C & $\begin{array}{l}\text { middle (LT B2-C2) La Tène without continuity to late La Tène } \\
\text { ('Němčice horizon') }\end{array}$ \\
\hline D & unspecified La Tène \\
\hline
\end{tabular}

Tab. 1. Systematics of the sites in the study area: working groups definition according to the chronology of sites. Al sites - late La Tène sites ('Staré Hradisko horizon'), i.e. LTC2-D1; C sites - middle La Tène period ('Němčice horizon'), i.e. $L T B 2-C 2 ; A 2, B 1, B 2$ sites - different variants of continuous sites (A2 - clear signs of continuity; B1-B2 - possibility of continuity). - Tab. 1. Systematika lokalit ve sledovaném regionu: definice pracovních skupin podle chronologie lokalit. Lokality typu A 1 - pozdní doba laténská (",horizont Staré Hradisko"), ti. LT C2-D 1; lokality typu C - středni/mladší doba laténská (",horizont Němčice"), tj. LT B2-C2; lokality typu $A 2, B 1, B 2$ - různé varianty kontinuálně osídlených lokalit (A2 - jasné známky kontinuity; B1-B2 - možnost kontinuity).

riod. This type can be referred to as a typical 'Němčice horizon'.

D: La Tène period in general, exact dating is not possible.

Based on collected data and their evaluation the systematics of the settlement structure is as follows:

Setting aside 'isolated finds' and 'traces' groups, we can identify various types among the categories of settlements. The typology of settlements was proposed by J. Waldhauser who divided them into several groups (Waldhauser 1993, 386, Tab. 59). This classification was later revised based on newly available information coming from most recent research. Based on specific features, settlements in the region were divided into several basic sub-types (Tab. 2):

\section{Settlements}

Isolated small settlements/homesteads/farmsteads Based on the current state of knowledge, these are typically isolated buildings/homesteads with no evidence of adjacent structures. These buildings may have served a variety of purposes. As for the region in question, there is probably only one example: a sunken house in Ohrozim (Čižmár 2015). The isolated feature was discovered thanks to excavations for a gas pipe. We are aware of no surface finds in the surroundings, perhaps due to the presence of colluvium covering potential other archaeological features. Even if it was really an isolated homestead, based on the discovery of items made from animal bones, it seems that some specialised activity took place at the site. Based on some particular finds (part of a ring-bead, Nauheim fibula) we can assume that it was a settlement benefiting from the direct connection to the central site, in this case the oppidum Staré Hradisko (Čižmár̆ 2015, 455).

\section{Common rural settlements without the evidence of specialised activities}

Based on the available information, it would appear that in the studied region the most common type of site is a rural settlement without the evidence of specialised activities, or even most common household production. ${ }^{2}$ We can basically assume their agricultural function, i.e. the crop production, animal husbandry (mostly cattle and pigs) and also basic household production (cf. Čižmár 2008 ) which in many cases is very hard to define from the archaeological perspective (e.g. animal production, textile production, working of hides, bones or antlers, domestic pottery production etc.). Archaeological evidence also does not so far support the presence of elite at these sites. We cannot say, however, that these settlements were completely cut off from an exchange or trade activities. On the contrary, they may have had their place within the local economic network around a central agglomeration.

\section{Agglomerations}

A concentration of several settlements with evidence of the specialised activities - agglomerations with central functions

The main centre of production and trade during the middle La Tène period was located at the central agglomeration of Němčice. The material assemblage from the site contains rich evidence of specialised production, including the monetary production, bronze casting or production of glass beads and possibly even bracelets (Čižmář - Kolníková 2006, 264, 266; Venclová 2016). Probably by the end of LT C 2 the settlement in Němčice had been reduced significantly for yet unknown reasons and the central place moved approximately $20 \mathrm{~km}$ to the northwest to an elevated location at the edge of the Drahany hills. The new centre, known today as the Staré Hradisko oppidum, replaced the former agglomeration of Němčice in many ways, especially politically and commercially. Archaeological sources suggest that

${ }^{2}$ This may be due to the state of knowledge of sites as most of them are known only from the surface surveys.
Tab. 2. Systematics of the sites in the study area: working groups definition according to the type of site. - Tab. 2. Systematika lokalit ve sledovaném regionu: definice pracovních skupin podle typu lokality.

\begin{tabular}{|l|l|}
\hline \multicolumn{2}{|l|}{ TYPE OF SITE } \\
\hline Isolated find & non-ceramic find (coin, iron or bronze object etc.) without known archaeological context \\
\hline Trace & $1-3$ ceramic fragments without known settlement features \\
\hline Settlements & $\begin{array}{l}\text { mostly surface scatters, but also excavated sites; } \\
- \text { isolated small settlements (homesteads, farmsteads) } \\
\text { - common rural / village settlements without or rare evidence of specialised activities }\end{array}$ \\
\hline Agglomerations & $\begin{array}{l}\text { larger rural settlements with evidence of specialised activities; } \\
- \text { 'major sites' (Němčice nad Hanou and Staré Hradisko): occupied in LT B2-C2 or LT C2-D1 respectively } \\
\text { - 'settlement agglomerations': several specific sites along the River Valová; more settlements sites close } \\
\text { to one another with possibly one central location or a type of 'habitat groupé'; continuity of occupation - } \\
\text { LT A-LT D1. }\end{array}$ \\
\hline Depot & votive, production, commercial or other intentional deposit of coins or other artefacts \\
\hline
\end{tabular}




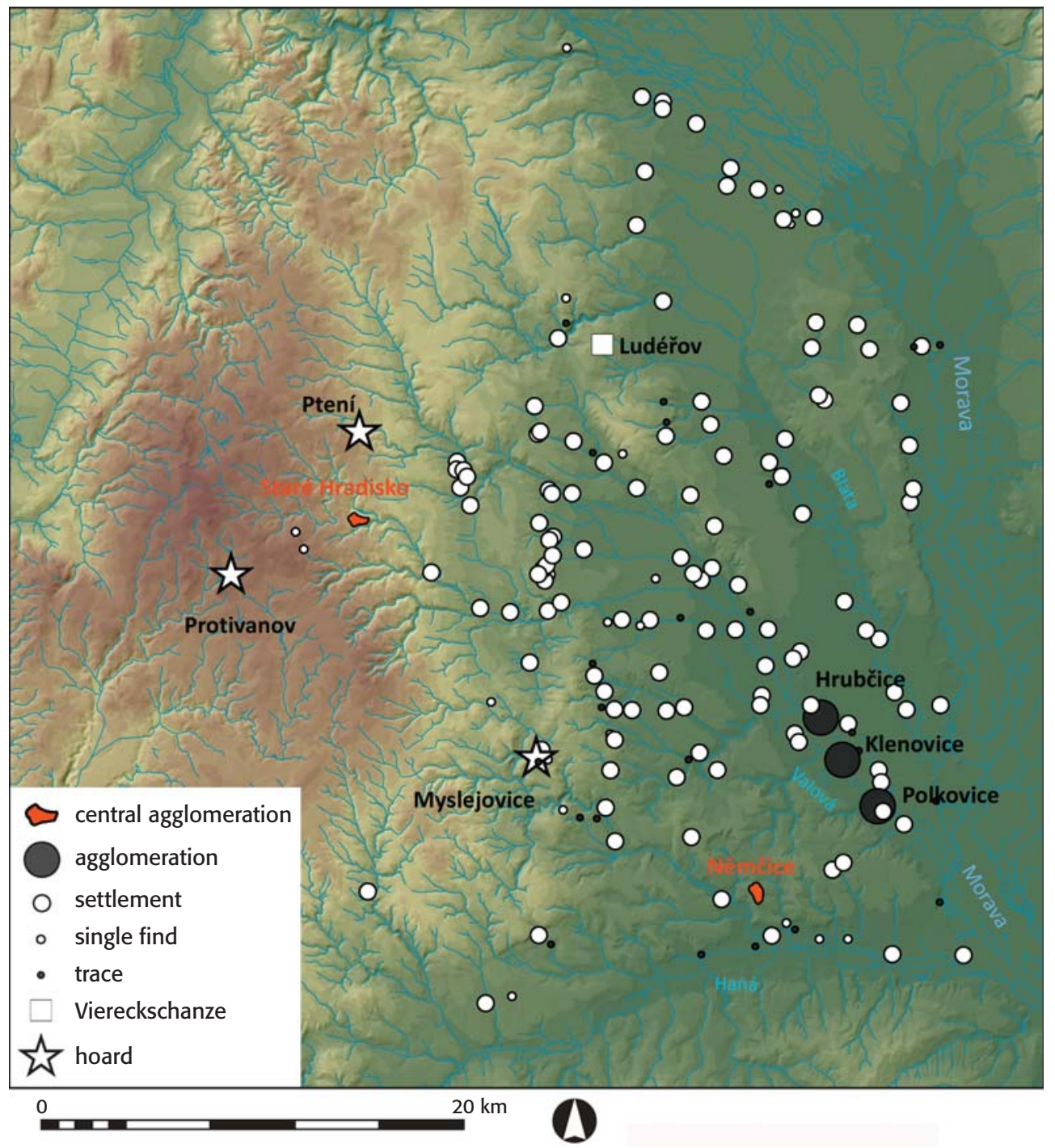

Fig. 4. Systematics of sites in central Moravia according to the type of site (data by I. Čižmář, author A. Danielisová). - Obr. 4. Systematika lokalit na střední Moravě podle typu sídliště (data I. Čižmáŕ, autor A. Danielisová).

the process of replacing one central site with the other was not abrupt and, for some time, the sites coexisted simultaneously.

The origin of communities living in these centres and the continuity of occupation remains a question. The current hypotheses would suggest that the elites of the two communities may have been unrelated in terms of their orientation of socio-political and commercial contacts. This is due, among other things, to the monetary systems that are not complementary to each other (e.g. Militky 2015; 2018) and also on the basis of the material culture by changing the overall orientation from the Middle Danube area to central and eastern Bohemia.

In addition to centres, also smaller settlements are identified in the archaeological record, which for this work will be referred to also as 'settlement agglomerations'. Sites of this type are much rarer than common agricultural settlements described above. Key identifiers include continuous occupation during the entire La Tène period (LT A - LT D) and dispersed settlement activities spanning several square kilometers and involving several settlement areas. Typically a site can be identified as such thanks to the finds evidencing the specialised pro- duction and the corresponding production waste (e.g. raw glass, scraps of glass beads or bracelets, scrap metal /bronze casting spills, etc./, semi-products, coin moulds, etc.). As is the case of the aforementioned sites, even here the continuous improvement of the state of knowledge could be expected, resulting in the updates to the list of known sites of this kind.

The term 'settlement agglomeration' refers to a cluster of several sites around a larger settlement (although not necessarily). The central functions of the site are identified usually thanks to higher intensity of specific finds within the area. From the chronological perspective, the finds tend to be older towards the centre and younger with the increasing distance from it (possibly as new settlement units are built). Settlement agglomeration can also be recognised by a loose concentration of household units dispersed over a large area (even several square kilometres); forming thus one large loosely interconnected settlement unit. In France, where these sites are quite common, this type of settlement structure is referred to as 'habitat groupé' (Deberge - Kurzaj - Lauranson 2019). In the Czech territory, however, this type was so far mostly unknown. 
Fig. 5. Systematics of sites in central Moravia according to chronology. Sites of group D were not more precisely chronologically classified and have not been further used in analyses (data by l. Čižmár, author A. Danielisová). - Obr. 5. Systematika lokalit na střední Moravě podle datování. Lokality skupiny D nebyly presněji chronologicky zařazeny a dále použity prĭ analýzách (data I. Čižmár̆, autor A. Danielisová).
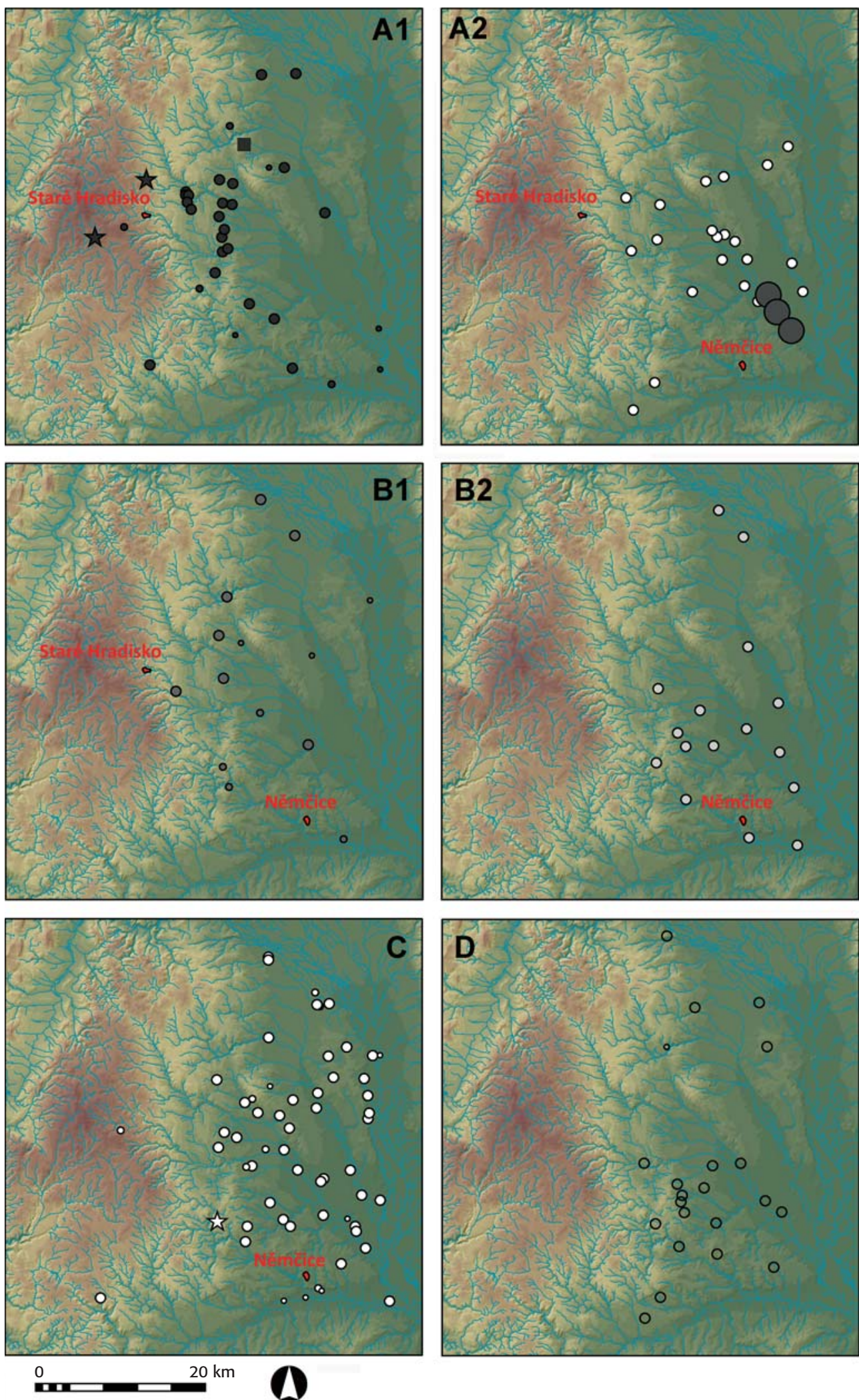

Several sites of this type were identified in the study region. Most of them were detected only thanks to the surface surveys revealing a specific spatial pattern connecting several settlement areas close to one other. Examples include the present-day Klenovice where the evidence of a continuous La Tène occupation was detected along the Valová River (at approximately $2 \mathrm{~km}$ long strip).
Similarly, in the village of Polkovice 'Ostrov' a La Tène settlement was found. Other La Tène finds are also associated with sites along the Valová River. A similar agglomeration is located in Hrubčice, also with a series of sites with La Tène finds spread along one-kilometre stretch. We can also assume that the site (known as 'Bažantnice') in Ivaň is also connected to the agglomer- 
ation in Hrubčice. Another interesting example is the settlement agglomeration in Ptení, a settlement area closest to Staré Hradisko oppidum. It is located at the natural corridor along the Romže brook which could have been used as a communication route between Haná and Malá Haná and eastern Bohemia.

Even though there are not that many settlement agglomerations in the region that we know about, there is one interesting aspect to them: they are not situated on east-facing slopes, as is the case of most settlements in the region. The agglomeration in Hrubčice faces to the south-west, as does the site in Držovice. The sites in Klenovice na Hané and Polkovice were situated on flat terrain along watercourses. Due to the possibly higher number of inhabitants, intensive mutual contacts are very likely, which in turn are related to production activities which in some cases had developed into more advanced specialised production. For example, evidence of coin production was detected at the site of Klenovice (a fragment of a coin-mould; Fig. 16:7). ${ }^{3}$ This find may probably explain the discovery of a larger number of coins at this site. A rare piece of evidence of glass production in the form of a semi-product of glass beads (Fig. 16: 6) was found in Merrovice where, on the other hand, there is no evidence of other settlements in its vicinity.

A common element of all settlement agglomerations is their long duration. All of them have been proved to exist both in LT B-C1 and in the late La Tène period, i.e. LT C2-D1. Therefore, they were settled continuously throughout the co-existence of both central agglomerations. It must also be noted that all mentioned sites were settled already during the Bronze Age, during the early La Tène period (LT A), and intensive activities took place there during the Roman period as well. An exception is the agglomeration at Ptení which only saw a significant development during the late La Tène period. It may be supposed that these types of sites were natural hubs within their settlement networks which could be involved in the structuring of the rural settlements in the region.

The settlement areas could also have included quadrangular enclosures, commonly known as the Viereckschanzen. In Bohemia, more than ten sites of this type is known so far (Venclová /ed./ 2008, 35; Danielisová 2020, Fig. 21). From Moravia, on the contrary, it is possible to mention only one case of this site at Ludéřov. The enclosure formed by an earthen rampart reaches dimensions of approximately $110 \times 110 \mathrm{~m}$ and is surrounded by an external V-shaped ditch. It was introduced into the literature by $M$. Čižmár $\check{r}$ (1973) and so far it is the easternmost locality of this kind. Its interpretation as a La Tène site, however, is not certain. Recently, a test trench was carried out here as part of a project dealing with the mapping of medieval roads. It was found that the entrance to Viereckschanze is older, and therefore it is likely that the enclosure is not of the La Tène age, but was built later (Martínek et al. 2013; Vrána 2014, 14). This finding

\footnotetext{
${ }^{3}$ Unpublished find deposited in Moravian Museum; no. 179498.
}

is indirectly supported by the fact that no La Tène material has yet been found within the enclosed area or in its immediate vicinity.

\section{Hoards}

With the wider use of metal detectors, hoards are now being routinely found all over the territory of Moravia. Most of them have been found in the hilly terrain of the Púchov culture in eastern and south-eastern Moravia. These are usually deposits of iron objects, craft and agricultural tools possibly of a ritual purpose. On the other hand, hoards are rare in areas associated with the La Tène culture; and their respective contents vary considerably.

The most significant deposition attributed to the La Tène culture is the one from Ptení (Meduna 1996; Čižmár̆ 2002a; most recently Hlava 2015). The assemblage contained bronze pendants in the shape of small legs and boots; bronze rings with human figures, bronze rings, and several glass and amber pearls. One of the reasons why this location was chosen in the mostly uninhabited hilly terrain might have been its remoteness, however, the deposition of the hoard in the proximity of the significant long-distance route probably was not accidental.

A second hoard found in central Moravia was a large assemblage of coins found in 1883 during the construction of house number 89 in the village of Myslejovice. According to initial information, there were 70 to 100 gold coins. Another hoard, found in Plumlov (50-60 coins), was first mentioned in 1886 (Radoměrský 1955, 78), and the one from Určice in 1887 (Gottwald 1913, 292). However, in both cases there is almost certainly a confusion with the find from Myslejovice which was ultimately sold by pieces to Prostějov and Vienna museum collections. ${ }^{4}$

The most recent find was made in Protivanov, containing two gold Boian staters. The purpose of deposition of the hoard remains unknown; accidental loss cannot be ruled out as well. The find of coins may be also linked to the existence of a communication route between Haná and Lysická sníženina.

All aforementioned hoards found in the region have one thing in common: they were found outside inhabited areas (possibly except for Myslejovice) and they were located in the proximity of long-distance routes.

\subsection{Evaluation of settlements based on location}

Each site was characterised by a set of variables: elevation, distance to the nearest watercourse, distance from the central place (i.e. Němčice or Staré Hradisko), sloping, soil cover etc. (Fig. 6-8). In certain cases, this characterisation could be biased due to the lack of precise localisation; especially the sites identified by surface prospections appear to be larger than they actually were due to modern ploughing. Sometimes the uncertainty of localisation can be as much a more than hundreds

\footnotetext{
${ }^{4}$ The fact that coins were sold may be confirmed by the fact that as years go by the quantity of coins in the so-called hoards decreases.
} 

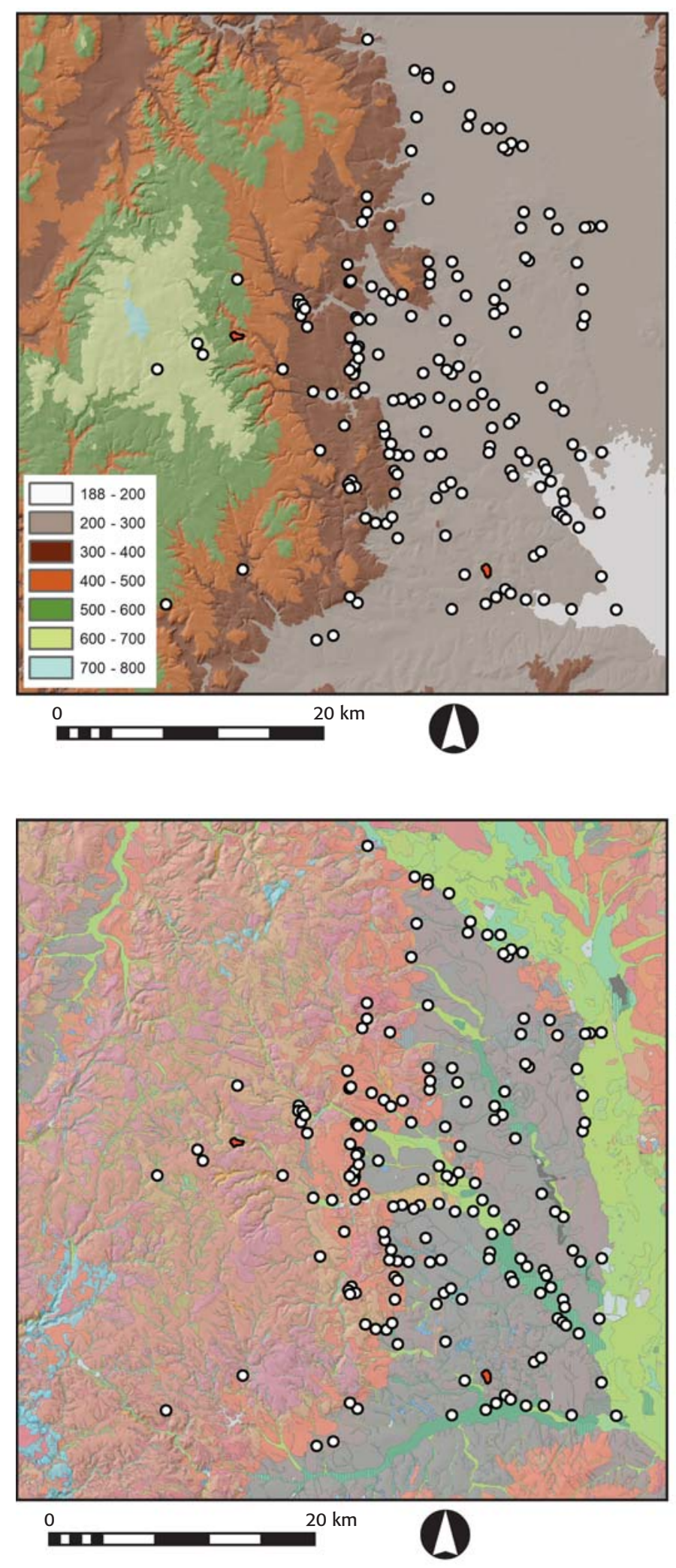

of metres. Therefore, these cases were excluded from further analyses. Even so, the database of central Moravian settlements represents a valuable source of information allowing for a robust analysis of the nature of the settlement pattern.

For most sites known from surface prospections, the process of cataloguing started with the identification of

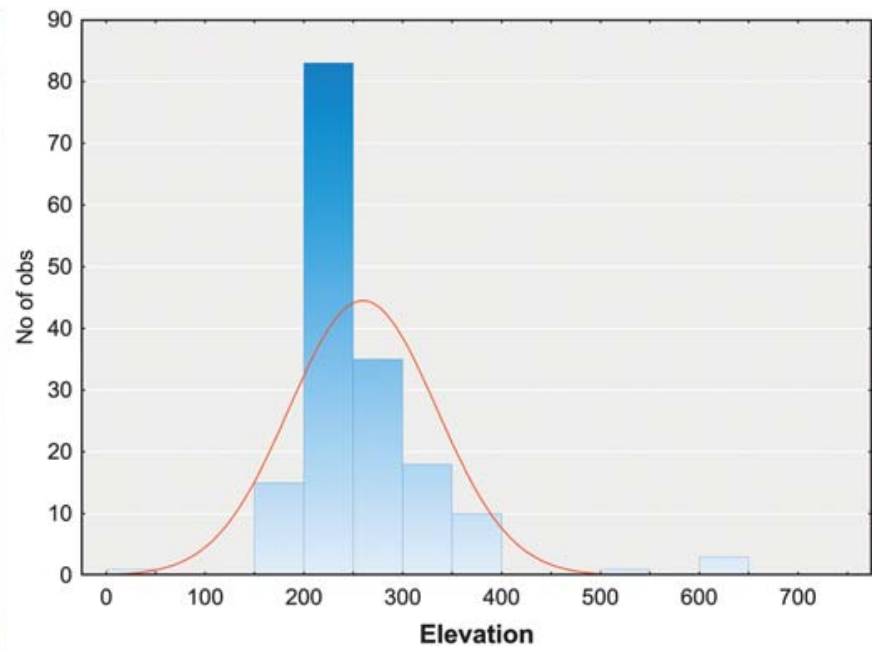

Fig. 6. Sites in central Moravia according to their elevation (author by A. Danielisová). - Obr. 6. Lokality na střední Moravě podle jejich nadmořské výšky (autor A. Danielisová)

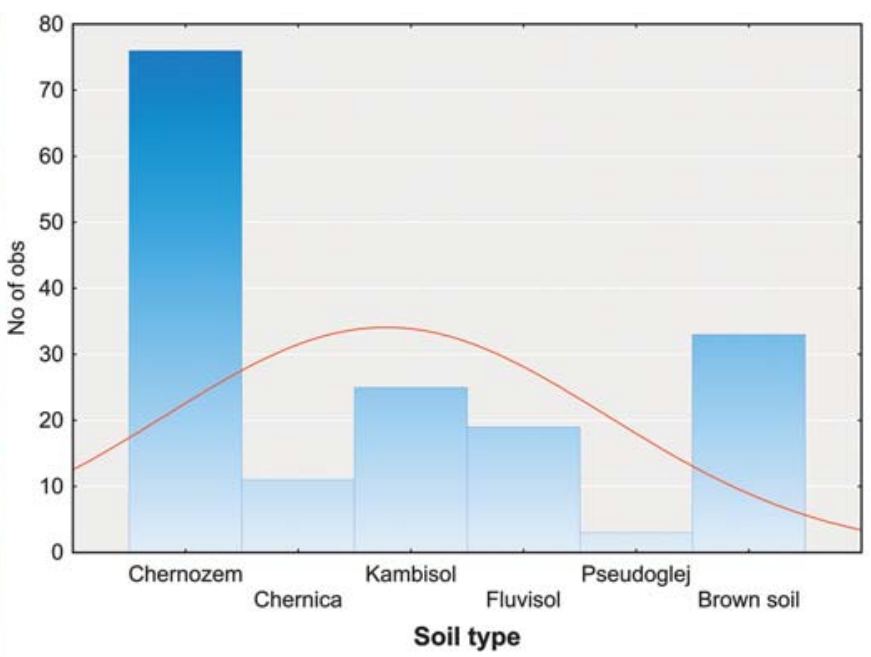

Fig. 7. Sites in central Moravia according to their soil type (legend cf. http://mapy.geology.cz). Author A. Danielisová. - Obr. 7. Lokality na středni Moravě podle typu půdy (legenda viz http://mapy.geology.cz). Autor A. Danielisová.

polygons in which the central coordinates were measured. It has to be noted that most polygons are affected by inaccuracies due to the localisation of the surface scatters. Naturally, these inaccuracies are even more prominent in the case of old prospection activities, identified only by the name of the site, which could not be reliably verified. 


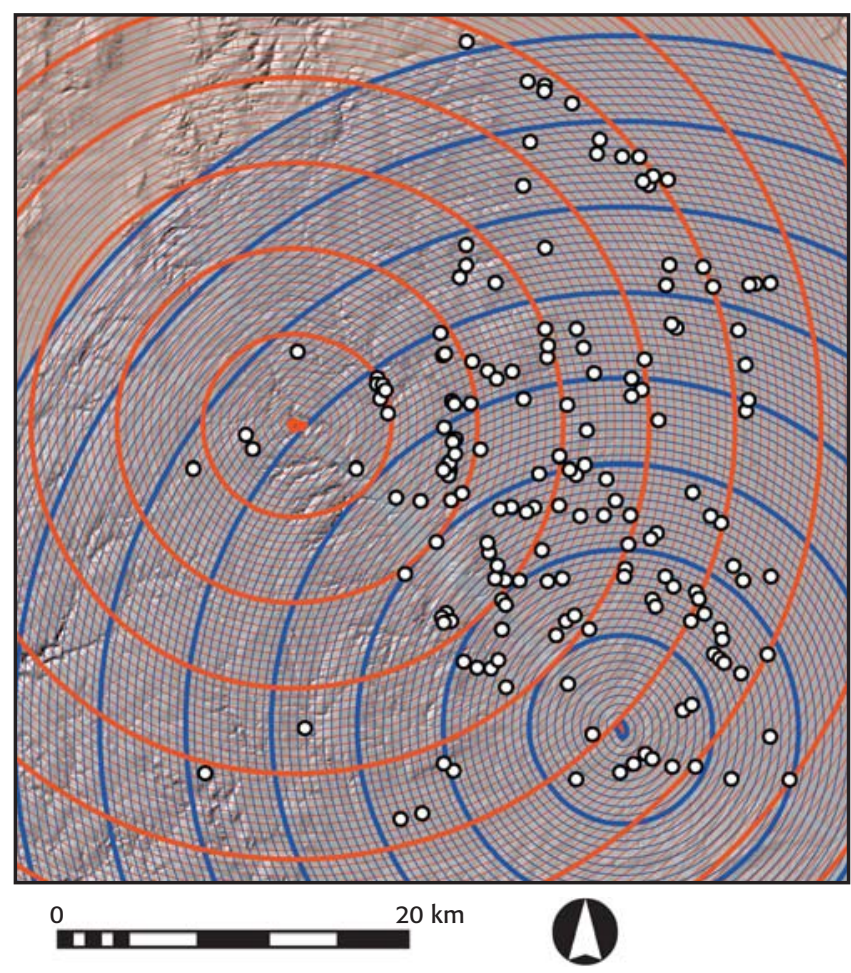

Fig. 8. Sites in central Moravia according to their distance from central settlements (Němčice - blue, Staré Hradisko - red). Distance units are 0,5 km, grouped to 1-hour walking distance (author A. Danielisová). - Obr. 8. Lokality na střední Moravě podle jejich vzdálenosti od centrálních sídel (Němčice - modře, Staré Hradisko - červeně). vzdálenost jednotek je 0,5 km, tučně jsou vyznačeny vzdálenosti jedné hodiny chůze (autor A. Danielisová).

\subsection{Chronological assessment of settlements}

Numerous experts have been concerned with the chronology of the late La Tène period. Of particular significance is J. Meduna's work where the La Tène period was divided into six horizons based on typical pottery shapes and decorations, and where each horizon would correspond to the respective relative phase from LT A to LT D (Meduna 1980a, 148). As for the late La Tène period, the relevant horizons are 5 and 6 corresponding to stages LT C2 and LT D1, respectively. However, the author himself has admitted that the differences between these two horizons are so minimal that mostly they require other categories of finds (metal brooches, coins etc.) to reliably support the chronological assessment (Meduna 1980a, 145).

In this region, chronological analysis was possible only based on the available archaeological material. Other aspects, such as types and nature of features and their position within the settlement, proved to be marginal or insignificant. As usually the chronology of most settlements must be established based on pottery only (and to a much lesser extent other time-sensitive finds) the current state of knowledge does not allow for more detailed classification using sub-phases.

In this work, a chronological system developed for Central Europe, used in Bohemia and Moravia, was used (Drda-Rybová 1998, 8; Waldhauser 2001, 41; Venclová /ed./ 2013, 22). For the purpose of this work, we estab- lished two main chronological phases: LT B2-C2 associated with the Němčice horizon (ca. 180-120 BC) and LT C2-D1 used for the Staré Hradisko horizon (ca. 150$50 / 40 \mathrm{BC}$ ). A still unsolved problem is the precise dating of the end of Němčice and beginning of Staré Hradisko within the LT C2. Apparently, for a generation, or even two, there was a chronological overlap between the two centres. Therefore, we must be aware of the fact that the LT C2 phase is associated with both the development peak of the agglomeration at Němčice and the foundation of the oppidum of Staré Hradisko. Unfortunately, at this time, LT C2 cannot be divided on the basis of material culture only. The beginning of Staré Hradisko was originally dated as the first half of the second century BC because of, among other things, Mötschwil type brooches (Čižmár̆ 2002a, 56). Based on the (so far very limited) hints of the material evidence, we can observe several differences in the assemblages of both agglomerations. For instance, the absence of the so-called 'Boian brooches' at Němčice and their presence at Staré Hradisko allowed for consideration of the chronological reason for this phenomenon and subsequent slightly later dating of the finds from Staré Hradisko (Čižmár - Meduna 2012). Similar idea was offered in case of certain types of bronze belt segments, specifically the types with lateral platelets and a central knob, so far observed commonly in LT C2 contexts, but not at Staré Hradisko (Mangel - Jošková 2019). However, the difference between the material culture of the two agglomerations may have its roots also in the different nature of their socio-cultural connections.

At this place, we will outline the basic characteristics of the material culture in each of the two later phases of the La Tène period in central Moravia; i.e. LT C2 and LT D1, respectively. Listed below is the characteristics of the main time-sensitive sets of finds from central places as well as from the rural settlements.

\subsubsection{Middle La Tène period (the Němčice horizon, LT C2)}

Coins - a catalogue of finds from the region was published by E. Kolníková (2012, 69-72); last evaluation was done by J. Militký (2018, 284-290). Coin systematics from the region corresponds to current numismatic models (Militký 2018, 12-13). The first group includes Niké type staters (Fig. 13: 1). These staters are dated to third and the second century $\mathrm{BC}$ and represent the oldest group of Celtic coins in Moravia (Hiriart et al. 2020; Militký 2008, 122). We can find them mostly in Němčice (Kolníková 2012, Abb. 1: 1-3), although only a few pieces (4) are present, oftentimes chopped in half. Later types include Athena Alkidemos type staters (Fig. 13: 3-7) and their nominals (1/3-, 1/8-, and 1/24-staters), inspired by coins of Philip V of Macedon (Kolníková 1998 , 22). Nominals of Athena Alkidemos staters occur in Moravia during the first half of the second century $\mathrm{BC}$ and together with the Niké type of staters they are abundant in Němčice (Čižmář - Kolníková 2006, 272273). A specific occurence is a unique coin, 1/3-stater of the type Athena / horse with a cross (Fig. 13: 2, cf. Kolníková - Černý 2006). 
In addition to gold coins, the Roseldorf/Němčice group of silver obols is known from the region (Fig. 13: $8-10)$. The silver coins weighing from 0.5 to $1 \mathrm{~g}$ had a horse on the avers. Many of them have been found in Němčice (as at 2012, over 200 pieces) as well as at other sites along the Amber Road corridor, such as Roseldorf and Nowa Cerekwia (Rudnicki 2014). They characterise the LT C1-C2 phase of the Němčice agglomeration (i.e. first half of the second century $\mathrm{BC}$ ) as it is very probable that the type Roseldorf/Nermčice I started to be produced already in LT C1 (Militký 2018, 287). Their occurrence continues well into the late $\mathrm{LT} \mathrm{C} 2$, as proved by the occasional finds from Staré Hradisko. The most common type is the one with a lyre, also probably in production since LT C1. Two basic types have beed recorded: A (Roseldorf/Němčice I, horse facing right), and B (Roseldorf/Němčice II, horse facing left), with many other sub-types (see Kolníková 2012).

Mötschwil type brooches - particularly significant for LT C2 were Mötschwil brooches which were common in the territory from the Rhineland to Carpathian Basin (Čižmár̆ 1970, 570; Meduna 1970a, 56ff; Márton 2004). Their dating to LT C2 is established based on the classification by F. R. Hodson $(1968,38)$ and is considered reliable (Gebhard 1991, 87; Čižmář - Kolníková 2006, 262), especially thanks to their occurrence at the necropolis at Manching-Steinbichel (Krämer 1985, 29).

In Switzerland and Bavaria, the Mötschwil type brooches were found in graves, while at sites more to the east they occured mostly at settlements as LT C2 graves are absent in this region (among the exceptions from Moravia we can mention late LT C 1 burial from Mistřín with two Mötschwil brooches). Meduna suggested that this type of brooch represents a major type which requires an extensive study (Meduna 1980a, 114; also Polenz 1971, 34ff; Stöckli 1974, 370ff; Márton 2004). This theory was confirmed later with growing activities of amateur archaeologists who multiplied the collections manyfold, especially in central Moravia. Most Mötschwil type brooches were found in Němčice - more than 70 pieces to this day (Čižmár̆ - Kolníková 2006, 262; for detailed analysis cf. Čižmář - Čižmářová Meduna 2018) - mostly made of bronze. ${ }^{5}$ As for the chronology, some shape and decoration development were identified: items featuring a serrated foot appear older as they were found alongside a LT C1 brooch in Mokronog, Slovenia (Guštin 1977, Taf. 12). Both bronze and iron specimens were found at the oppidum of Staré Hradisko (Meduna 1970a, Taf. 13: 3-5; Meduna 1980a, 114). From our observations (presence/absence at settlements and according to stratigraphy) it seems that the larger pieces (e.g. Fig. 12: 7) belong to end LT C1 LT C2, while the smaller bronze pieces (e.g Fig. 12: 1, 2) could represent the older period of Nermčice, i.e. LT C1 (Čižmářr - Čižmářová-Meduna 2018, 20). However, this observation does not have to apply in all cases. For example, at the oppidum of České Lhotice, a small bronze Mötschwil brooch was found within the stratigraphy of

\footnotetext{
5 This condition may be affected by the method of prospection at the site (metal detector survey) which suppresses the iron objects.
}

the fortification (Danielisová 2010, 41, 56). Evidence of the local production of Mötschwil brooches is supported by material analyses (see chapter 2.4) corresponding to other categories of local production at Němčice (especially the belt segments).

Belt parts with lateral platelets - contemporary to Mötschwil brooches and typical for the peak of the occupation of Němčice were the belt parts with lateral platelets and a central knob (Fig. 10: 11). The more detailed chronological assessment (cf. Mangel - Jošková 2019) was possible namely thanks to a large Němčice collection dated to LT B2-C2. Judging from the particularly numerous assemblage including the semi-products, we can conclude that they were produced locally (Čižmár̆ - Kolníková - Noeske 2008, 264, Abb. 8: 1-3, 9: $3,5)$. This theory is supported also by the material analysis (Fig. 14-15, and chapter 2.4) and the fact that they were also found at other settlements in the Němčice's surroundings. Belt parts with lateral platelets sometimes also occur at some late La Tène period sites (Pieta 2000, 142); no such find, however, was recorded at Staré Hradisko. This allows us to consider these belts to be typical for LT C2 (at least in central Moravia), but perhaps not for the part contemporary with the oppidum of Staré Hradisko (if we don't consider their absence at the oppidum for other reasons). The belts also included other elements, such as animal-shaped belt hooks or decorative pendants.

Glass - glass objects must be mentioned here because of their abundance; especially bracelets and beads that were probably manufactured in Němčice. Their occurrence in central Moravia is associated mostly with LT C2. The most common glass jewellery are bracelets of types $13 \mathrm{a}, 8 \mathrm{~b}$ and $3 \mathrm{a}$ with a long chronological timespan until the late La Tène period. The same applies to monochromatic cobalt-blue beads belonging to groups 117 and 155 , also possibly produced locally (Venclová 2016, 59-60, Fig. 84, 88).

Ceramics (Fig. 11: 1-17) - pottery in LT C2 is not particularly indicative as many characteristic traits can occur also in the late La Tène period. For example, uneven vertical combing is present on pottery pieces dating to LT C 1 as well as the polished wavelets or bands. Rim shapes change into protruded forms transforming into club-shaped and cornice-shaped profiling. These shapes are typical for LT D1 as well. It appears that beside a few exceptions (see below) pottery dated to this period is not distinctive enough for the reliable dating of settlements.

The most distinctive formal feature in the middle La Tène period (LT B-C1) in central Moravia are graphite situlae decorated under the rim with strips of stamps in the form of an inverted $\mathrm{C}$ or other stamped motifs (cf. Meduna 1980, 67-68; Hlava 2008, 218; Poulová 2011, 221-224; Danielisová 2015, 178-180). The frequency of finds decreases with the increasing distance from the agglomeration of Němčice (Fig. 9). Sites with this type of ceramics, and at the same time with the absence of later finds, can be reliably dated to the middle La Tène period, i.e. in this work LT B-C1. 


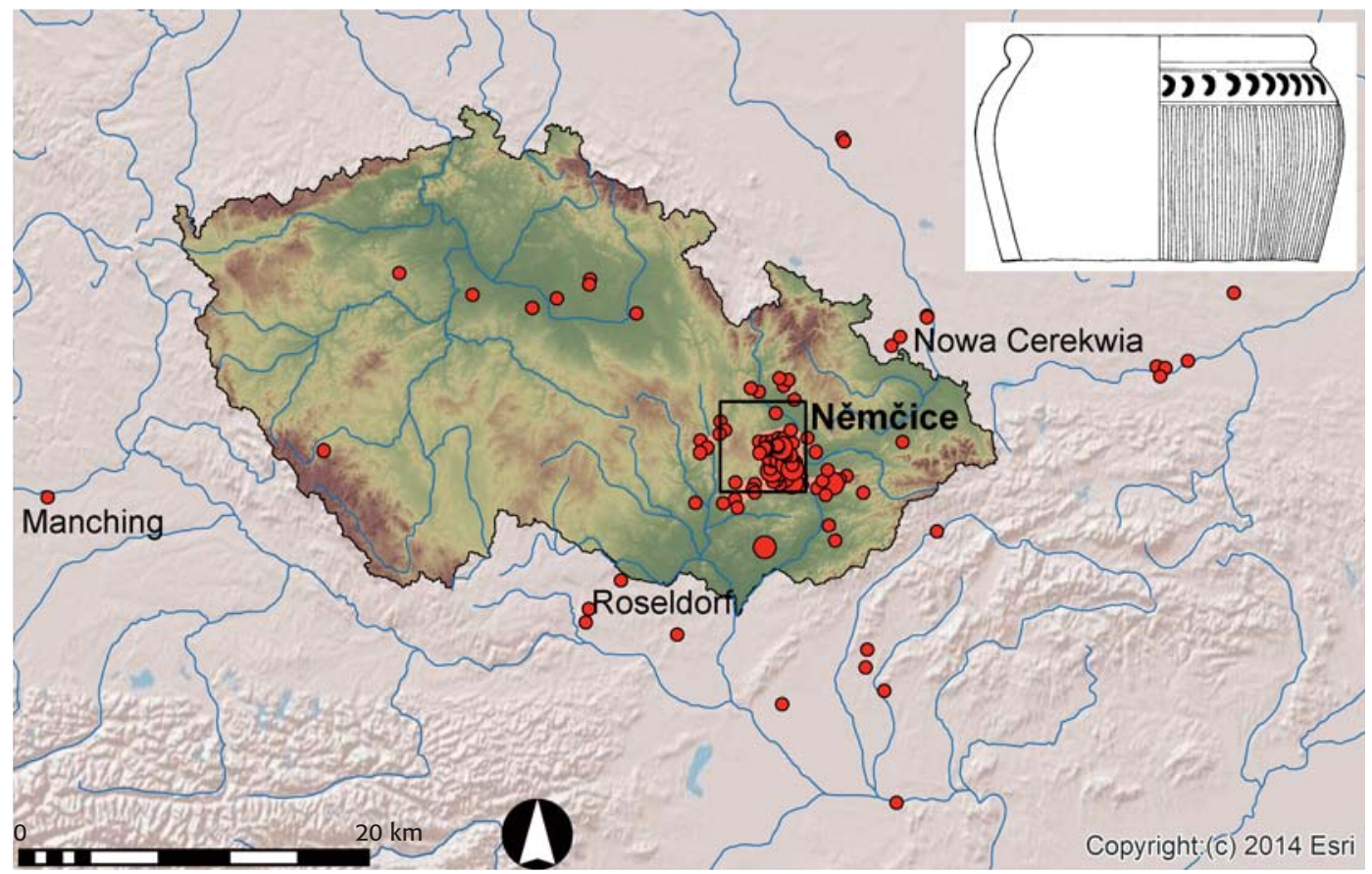

Fig. 9. The original distribution area of the C-stamped graphite situlae and their finds in the Central European area. Rectangle marks the study area (after Danielisová 2015). - Obr. 9. Pưvodní distribuční okruhy situl s pásem kolků ve tvaru obráceného $\mathrm{C}$ a jejich nálezy ve středoevropském prostoru. Obdélník označuje sledovanou oblast (podle Danielisová 2015).

In LT D 1 we notice a significant trend in the decreasing of graphite content in the pottery. This was already observed by M. Čižmář in his publication of the La Tène settlement in Strachotín (Čižmár̆ 1987, 223). The amount of data available to us at this point would support this observation. The possible reason may be the limited distribution of the graphite material towards the end of the La Tène period. In the middle La Tène period (Blažovice, Ohrozim-JZ, Prostějov-Čechovice), ceramics with high graphite content dominates over common coarse pottery. In the analysed assemblages, it usually represents more than 30\% (Hulín, Milonice, Určice). On the contrary, in the late La Tène period the common coarse pottery usually outweighs the graphite ware (Blansko, Bořitov, Brno-Slatina, Dětkovice, Ohrozim, Rychtárov), which is usually around $10-15 \%$ of the assemblages. Exceptions to this observation include the La Tène settlement at Unčovice where graphite pottery exceeded $50 \%$, or other settlements at Hněvotín, Slatinice and Čechy pod Kosířem, also with higher number of graphite pottery (around 30\%). The percentage of graphite pottery also decreases with increasing distance from the centre of production and sources of graphite (Venclová /ed./ 2008, 81-82; Hlava 1997). This observation can be explained by the location of graphite deposits some $20 \mathrm{~km}$ away (Fig. 22) between Svinov and Květín where raw graphite was probably exploited during the late La Tène period. Pieces of the raw graphite were found also at Mohelnice (the proven exploitation site), Unčovice, ${ }^{6}$ Náklo, Hněvotín and Olomouc-Neředín. Furthermore, the significant graphite content in the case of pottery found in Slatinice and Čechy pod Kosířem (Hlava 2008, 206-209) may be related to the

\footnotetext{
${ }^{6}$ A lump of raw graphite was found in a pit in Dolní Sukolom where the ratio of raw graphite pottery was around $50 \%$, similar to that of the nearby Brníčko settlement (Hlava 2008, 203).
}

communication route to Staré Hradisko where the proportion of graphite pottery is significantly higher around $30 \%$.

\subsubsection{Late La Tène period (the Staré Hradisko horizon, LT C2-D1)}

Coins - typical representatives of gold coins in Moravia in the late La Tène period are the Boian staters of the so-called shell series (Fig. 13: 13) which belonged to the same monetary system as Bohemia. In the lowland settlements, we encounter mostly individual finds of these coins (Držovice, Otaslavice, Prostějovičky, and the unpublished hoard from Protivanov). Other mintages, such as the type with a 'hump', also appear (Fig. 13: 12, Hrubčice). Quite specific and exceptional specimen is the stater with a motif of Pegasus from Ptení (Fig. 13: 11, Castelin 1965; Kolníková 1998, 25). From the lowland settlements, only 1/8- and 1/24-staters are known so far. The former are characterised by the abstract motifs. One find can be mentioned from Hrubčice (Fig. 13: 14). Another, now lost, specimen from Dzbel featured a T-shaped motif. Various variants of $1 / 24$-stater with abstract motifs (Fig. 13: 15) are specific for the Moravian territory. These were found during the recent prospections at Klenovice and Měrovice agglomerations.

Small silver coins dated to the late La Tène period are represented by the obols of the type Staré Hradisko, especially different variants of the type E (Fig. 13: 16). However, there were also obols of the Staré Hradisko D type, which also included variant with a stylised head (Fig. 13: 18) or the head with (Fig. 13: 17) a left-facing head with a long nose and large eye with a hairstyle styled as S-shaped lines. One piece of this coin was found at Staré Hradisko (Meduna 1970a, Taf. 16: 9), and one at Manching (Egger 1984, Tab. 26: 76). These 

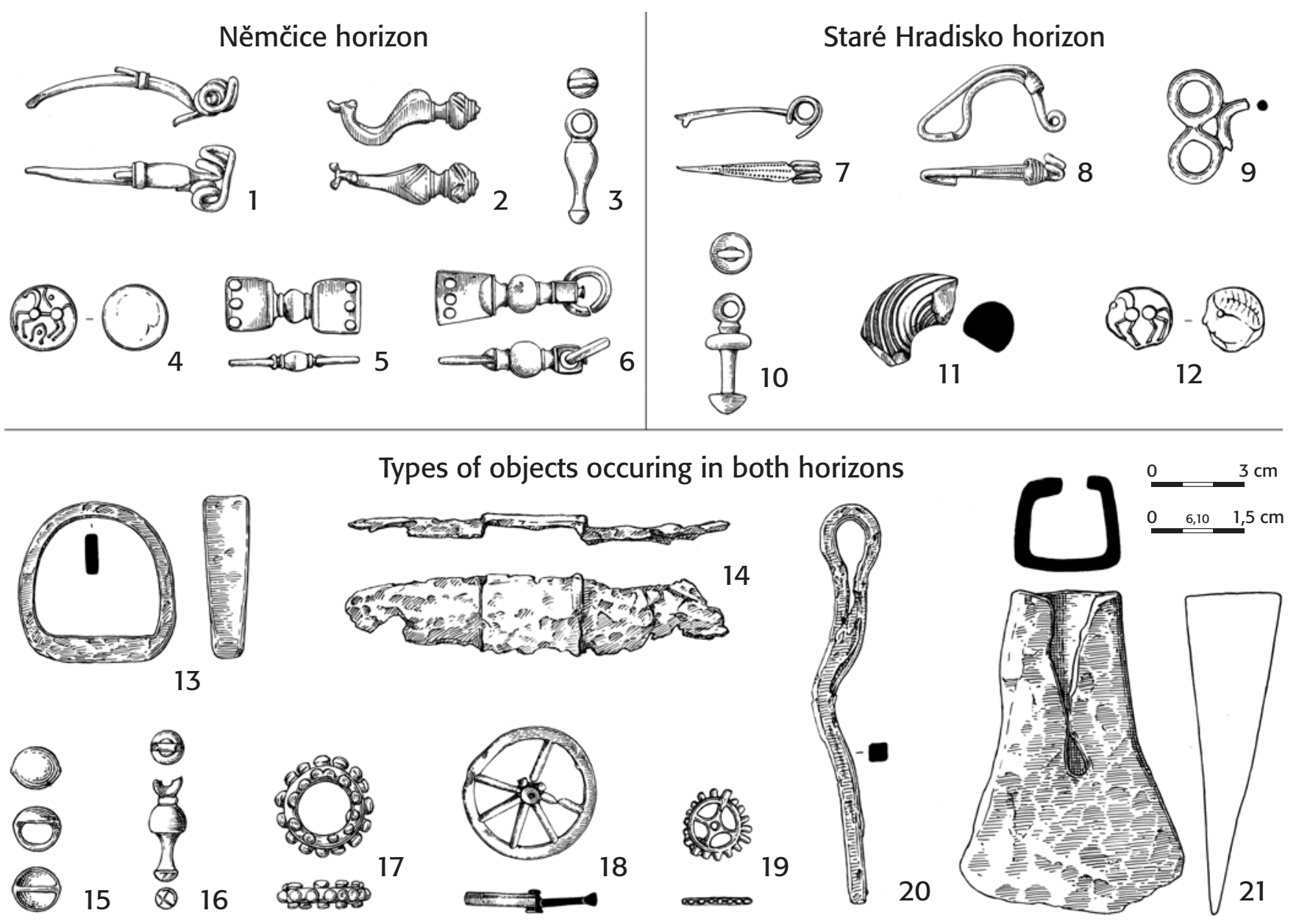

Fig. 10. Comparison of selected types of non-ceramic finds from rural settlements in the study area typical for the Němčice and Staré Hradisko horizons: 1-3, 9, 15, 16 - Polkovice; 4-6, 10-13, 19 - Klenovice; 7, 14, 20 - Ohrozim; 8 -Dětkovice; 17-18-Měrovice; 21 - Němčice 'Pastvisko' (drawings by A. Krechlerová). - Obr. 10. Porovnání vybraných typů drobných nálezů ze sledovaného regionu typických pro horizonty Němčice a Staré Hradisko: 1-3, 9, 15, 16 - Polkovice; 4-6, 10-13, 19 - Klenovice; 7, 14, 20 -Ohrozim; 8 - Dětkovice; 17-18-Měrovice; $\mathbf{2 1}$ - Němčice "Pastvisko" (kresba A. Krechlerová).

coins were most definitely produced at the Staré Hradisko oppidum (Čižmář 2002c, 302; Militký 2015, 116). An import from the west is represented by the silver obol of the Pollanten type (Fig. 13: 19). Compare to the previous Roseldorf/Němčice type (weight $0.5-1 \mathrm{~g}$ ), the weight of the late La Tène obols does not significantly exceed $0.5 \mathrm{~g}$ and they feature more stylised motifs. They are assumed to be dated to the first half of the first century $\mathrm{BC}$, or to the very end of the second century $\mathrm{BC}$ (Kolníková 2007, 447; Militký 2015, 117). From the lowlands, we can mention six pieces from the Klenovice agglomeration, two pieces from Polkovice and one piece at Hrubčice and Klopotovice, respectively (Kolníková 2012, Abb. 87: 9, 17; 88: 15-19; 90: 10-11). None of them weighs more than $0.5 \mathrm{~g}$.

Within the studied region there is no recorded occurrence of the Karlstein type of obols. This widely produced late type of small silver coins, known from the Boian regions (Kellner 1990; Militky 2015) north of the Danube, is mostly associated with the LT D1b and represents final phase of the local coin production. The fact that they are virtually unknown from the Moravian territory corresponds with the other evidence on the declining occupation in this period.

\section{Brooches}

Nauheim type - this type of brooch is widespread from the territory of Gaul to the Carpathian Basin and it represents an older phase of LT D1, i.e. LT D1a typical for the oppidum period (Karasová 2002, 250; Krämer 1962, 308; Demetz 1999; Danielisová 2020). As for the territory of Bohemia and Moravia, the main occurrence of these brooches is dated to LT Dla (e.g. Danielisová 2020, 117-121), while younger types are rare and usually limited to oppida or other hillfort sites (Danielisová - Militký 2014, 45; Danielisová 2020, 117; Striewe 1996, 169). Beside Staré Hradisko, only a handful of brooches of this type are known from the studied region. Not so long ago we only knew of three pieces (cf. Meduna 1980a, 115; Čižmář 2003, 38, Fig. 9: 1, Tab. 30: 3; Čižmářová 2004, 263). Metal detector survey between 2006 and 2010 significantly contributed to the current state of knowledge; now we know of 10 cases from the rural settlements where this type has been found since (Čižmář - Čižmářová - Kejzlar 2011, 92). One piece was found in late La Tène sunken hut in Ohrozim (Fig. 12: 9; Čižmář 2015, 440-441, Fig. 5: 1), and another one was found during the surface prospection in Pustiměr 
and Klenovice na Hané (Fig. 12: 10-11). ${ }^{7}$ These brooches were probably produced at the oppida and fabricated from local materials. Their geochemical data can possibly be related to individual workshops, or, at least, individual sites (cf. chapter 2.4).

(so-called) Boian brooches - this unique type of brooches (whose detailed list from Moravia was published by Čižmár - Meduna 2012, 348-349) is not very common in our territory. They are dated to LT C2-D1, probably its earlier phase. Boian brooches are yet another category of items which separate, at least in terms of chronology, the material culture of both central agglomerations. Out of 120 known brooches from Němčice (as in 2005, cf. Čižmář - Kolníková 2006; Čižmář Čižmářová - Meduna 2018, 46), none of them is of this type; we can thus assume that their occurrence is limited to the oppida. Their presence in Moravia should be related chronologically to the foundation of Stare Hradisko. Their occurrence is recorded solely in the Bohemian-Moravian territory; hence their naming the 'Boian brooches' (Čižmář - Meduna 2012). In addition to the brooches from the oppidum itself, other finds are known from the late La Tène fortified site Loučka 'Obírka' or the Púchov site Štramberk 'Kotouč'. As for the rural settlements, we can mention a find from Klenovice na Hané which was occupied also in LT D1 (Čižmár̆ - Meduna 2012, 353). The last localised find from Moravian territory comes from Bohušice near the present-day Moravské Budějovice where late La Tène pottery was also found which was interpreted as related to central Bohemian production circles (black coating under the rim, Meduna 1980a, Taf. 6, 7-10). These objects started to appear in Moravia after the foundation of Staré Hradisko and many other new settlements in the countryside. We may therefore assume a connection with Bohemia where this material culture is more abundant.

Beltz, var. Jot type - this type is very rare during the period in question; aside from Staré Hradisko, we only know of one occurence in a sunken hut in Dětkovice (Fig. 12:13; Čižmář 2012a, 89, Fig. 5: 5) and, more recently, Doloplazy (Fojtík 2018, 189). The rare occurrence of this brooch corresponds with other finds from Moravia, as there are only four of these so far. These brooches are most common in central Germany and the area between the rivers Elbe and Oder (Werner 1955, 176f, Karte 2; Břeň 1964, 218; Völling 1995, Beilage 1; Danielisová 2020, Fig. 4: D). Perhaps, due to the direction of contacts, they are more frequent in Bohemia than in Moravia (Danelisová 2020, 117-118, Fig. 4: C). The brooch from Dětkovice is missing a knot on its bow just like its analogy from Staré Hradisko (Meduna 1961, 18, Taf. 9: 7). Another Beltz J brooch from the oppidum features a knot (Meduna 1961, 18, Taf. 9: 8), as does the brooch found at the settlement near Rajhrad (Ludikouský 1973, 42, Tab. 31). The Beltz J brooches accompany most of the other late La Tène brooch types - from the late Nauheim, Almgren 65, Schüsselfibel to Almgren

\footnotetext{
7 Unpublished finds deposited in Moravian Museum; nos. 177659 179387.
}

18 (Völling 2005, Abb. 14; Tappert 2007, 197-198). In Moravia, they are mostly associated with contexts from LT D1 phase.

Almgren 65 - this type of brooch is the most common in the Middle Danube area and the Bohemian-Moravian region, especially at the oppida where the brooches represent their final phase in LT D1b (Demetz 1999, 28, 48; Sedlmayer 2009, 118-119; Danielisová 2020, 117; Danielisová - Militký 2014, 49-50). Although they were fairly common at Staré Hradisko (e.g. Meduna 1961, Taf. 4: 2, 3, 5, 6, 8, 9, 13; 1970a, Abb. 9: 10, 13), not a single piece has yet been found at any of the lowland settlements. As for settlements in other parts of Moravia, we can mention Almgren 65 brooches from Bořitov or Plenkovice (Čižmář 2003, 38).

Other types of brooches - other types of brooches were, albeit rarely, also encountered. These include, for example, a larger brooch with a foot adjacent to the arched bow and with two spirals with an internal chord from the Rychtářov site (Fig. 12: 12). It can be assigned to type $21 \mathrm{~b}$ according to $R$. Gebhard (1991, 86, Taf. 38: 572-40: 605). Brooches of this type are dated to late La Tène (no earlier than LT D1). Another type of brooch represents a unique finding of a slightly deformed bronze specimen with an adjacent foot (Fig. 12: 14) with a long winding (approximately $6+6$ loops) and an external chord. Brooches of this type are typical mainly for the area of northwestern Slovakia and in Moravia they occur more in the area occupied by the Púchov culture. From this area a similar specimen from the Stramberk 'Kotouč' hillfort (Čižmář 1990, Abb. 2: 5, 6) and perhaps also one from the Jičina 'Požaha' (Čižmář 1993, 94, Abb. 1: 10) are known. These brooches also occur at Staré Hradisko. They were mostly manufactured in iron, but in these two cases they were made of bronze (M. Čižmář personal communication). A majority of finds of these brooches in the Púchov area was published by K. Pieta, who dates them at the turn of LT C2 - LT D1 (Pieta 1982, 26, Taf. IV; 2008, 57, 60, Fig. 25.B).

Rotary querns - late La Tène stone querns were commonly used devices for processing cereals. Many of them were found at Staré Hradisko where querns were transported not only from the vicinity of Kunětická hora in the eastern Bohemia (tephritic phonolite), but also from more remote areas in central Bohemia and Burgenland (Čižmář - Leichmann 2007, 14-16; Danielisová - Mangel - Drnouský 2011). It is also assumed that querns were made locally in the region using raw materials exploited at the eastern slope of the oppidum and used also as a construction material for the outer fortification wall (Přichystal - Opravil 1992, 116; Novotný Slobodník 2003, 54). The high number of querns at Staré Hradisko (LT C2-D1) and their total absence at Němčice (LT B2-C2) show that they might date only to the late La Tène period. Querns are not commonly found at rural settlements. A list of finds from Moravia was published in 2007 (Čižmár̆ - Leichmann 2007, 121-124). As for the region in question, querns (or their fragments) were found at three settlements: Lutotín, Rychtářov and Unčovice. Other milling stones are only 
referred to in publications: an entire La Tène quern was excavated in Stichovice; two pieces were found in Třebčín (Gottwald 1924, 110). ${ }^{8}$ Sources also refer to other places, e.g. from Biskupice and Držovice.

Ring-beads - glass ring-beads were made using the same technique as bracelets, but they only appear since the end of LT C2 and continue well until LT D1b (based on the Bavarian chronology, cf. Danielisová 2020, 114115). They probably served as pendants or amulets and they are most commonly found at the oppida. They were fabricated from the same material as the bracelets; sometimes the heterogeneous layered opaque core is covered with a thin layer of better-quality transparent glass by the so-called Überfangtechnik (Venclová 2016, 55). Typologically they can be divided into several groups (Haevernick 1960; Venclová 2016). Only six specimens are known from the lowland settlements so far. They include the group 21 bead in a hoard in Ptení (Hlava 2015, 269, 273, Fig. 11: 13) ${ }^{9}$ and Polkovice (178826), the wavelet-decorated type 23a bead from Ohrozim (Čižmár 2015, Fig. 5: 4), and the group 23 bead with a 'swirl' motif from Klenovice (177738), Mezice (A137041 VMO) and Otaslavice $(038504, \mathrm{M} 279 / 3)$. None of the finds from the rural settlements belongs to groups 24 and 25 whose onset dates to LT D1. A relatively low number of ring-beads is documented in Němčice, but, on the other hand, an assemblage from Staré Hradisko contained 202 pieces, making it the third-largest assemblage in Europe. In this set, types 23, 21 and 24 are the most common (Venclová 2016, Fig. 81).

Ceramics (Fig. 11: 18-32)

Painted ware - the site, where this type of fine wheelturned and painted ware is found, can be dated, with some degree of confidence, to the oppida horizon, i.e. the LT C2-D1. This type of ceramics is so far totally absent at Němčice. Production places of the painted ware have not yet been identified, but the most probable seem to be the workshops at Staré Hradisko. In general, we record only isolated fragments of painted ceramics from the sites in the region, but one whole vessel comes from sunken hut in Hněvotín (Ženožičková - Nohálová - Vaněček 2016) and larger number of fragments was found in the sunken features in Dětkovice and Ohrozim (Čižmář 2012a; 2015). It was at these two settlements that painted ceramics was found together with the late La Tène brooches, which confirms its dating to the LT D1. The increased occurrence of the painted ceramics recorded in the Prostějov region (Čižmář 2003, Fig. 21 ) suggests the link with the oppidum and its production and distribution networks.

\footnotetext{
8 The museum in Prostějov keeps eight La Tène querns or fragments with unknown locations, so they cannot be identified. In 2003 M. Hlava reviewed them. Based on data published by A. Gottwald the querns from Stichovice and Třebčín were provided to this musem, which is why it is almost certain that all of them are among these eight.

9 The Ptení hoard originally contained three beads; in addition to the one mentioned here, there was one non-decorated blue specimen (group 21) and part of a purple bead with white dots (group 24; Hlava 2015, 269-270, Fig. 3: 7).
}

Grated surface and 'central Bohemian' ware (Fig. 11: 24) - with the founding of the Staré Hradisko oppidum, new traits on ceramics appeared that are attributed to the influence of the Bohemian ceramic production. One of them is the so-called grated-roughening, which has a primary occurrence in central and eastern Bohemia (Meduna 1980a, 73; Čižmář 2003, 58; Venclová 2001, 30; Danielisová 2010, 88; Valentová-Šumberová 2007; Motyková-Drda-Rybová 1990, 354). Apart from Staré Hradisko this type of ware was found also at surrounding settlements, specifically Bořitov (Čižmář 2003). This type of the surface treatment was observed in Bohemia since the end of LT C1 (Venclová 1998, 160; 2001, 3032; Salač 1993, 134; Jansová 1964; Rybová 1969, 398; Čižmář 1994, 602), but its appearance in Moravia cannot be dated earlier than LT C2, because of its absence at Němčice and similarly dated sites, and, on the contrary, its presence at Staré Hradisko.

Pitch-black coating (Fig. 11:24, 26) - this surface finish is not associated with the single vessel type but can be found on situlae, bowls with in-turned rims or even large storage vessels (Meduna 1980a, 106). Similarly to the grated surface, the black coating appears in Bohemia already in late LT C1 (Venclová 1998, 158-159). In Moravia, on the other hand, the pitch-black coating appeared at settlements no earlier than in the oppida phase of the LT C2. Again, this type of surface treatment was not so far recorded at Němčice, but was regularly observed at Staré Hradisko. In the whole study region, this type is associated exclusively with the oppidum and contemporary lowland settlements, so it may allow us to determine the dating of this material with more certainty.

Storage jars with cornice-shaped rim (Fig. 11:25) large pot-like vessels referred to as 'storage jars' occur throughout the La Tène period but their frequency increases towards its late phase (Hlava 2002a, 318; Rulf - Salač 1995, 383). Typical shapes include cornice-shaped rims, often with the black coating. They are usually found at sites contemporary with the oppidum.

Fine keg-shaped drinking vessels (Fig. 11: 18, 19) a typical and easily recognisable type in terms of chronology are keg-shaped drinking vessels dated to LT C2-D1 (Meduna 1980a, 74-75; Čižmář 1987, 221, 223; Hlava 2002a, 319). They are common at Staré Hradisko (Meduna 1970b, Taf. 45: 14, 15, 17, 19-32, $34,35,37$ ), but much less at rural settlements (only five cases to this day); they appear at settlements in Ohrozim and Ptení (sites 1 and 6), other finds come from Dětkovice, Otaslavice and Určice.

Lids (Fig. 11:22) - lids represent yet another smaller category of pottery typical only for the late La Tène sites. To this day, no finds of this type are known from middle La Tène sites. ${ }^{10}$ Only a handful of Moravian sites can be listed when it comes to lids. Two fragments come from Staré Hradisko (Meduna 1970b, 60, 93, Taf. 46: 1-2).

\footnotetext{
${ }^{10}$ However, their rare occurence was recorded in flat-grave burials (e.g. Brno-Maloměřice - Čižmářová 2005, Fig. 66: 4).
} 
More recently a lid handle was found outside the ramparts (Čižmár 2008, 42, tab. 24: 11). From the site at Dětkovice three fragments of lids made from fine clay material (Čižmár̆ 2012a, Fig. 8: 7, 8) are known for which there is no analogy in Moravia. Two fragments from Ptení are also thought to be coming from a lid (Čižmář - Hlava - Šmíd 2005, 283, Fig. 2: 6; 3: 9). Another specimen is from the more distant Doubravice (Meduna 1980b, 74, Taf. 15: 17).

Stamped pottery - stamped pottery is usually typical for the early La Tène period settlements. Today there are more than 50 known sites (Hlava 2000). Stamped pottery is somewhat rarer during the period of flat burial grounds (LT B1-C1). During the late La Tène period, its appearance is negligible. As for our region, this type of decoration has only been found at Staré Hradisko - 25 fragments (Meduna 1970b, Taf. 57: 9, 10, 13; M. Čižmář personal communication). Somewhat different stamped pottery motifs are featured on a vessel whose fragments were found in a settlement pit in Bílovice-Lutotín. Its decoration in the vessel's upper part consists of regularly spaced concentric rings with diagonal and lateral bundles of lines, mutually interconnected. No analogy has been found yet.

Marks/stamps at the bottom (Fig. 11:31) - in 1985 M. Čižmář and J. Meduna presented a list of all sites with finds of pottery with marks at the bottom (Čižmár - Meduna 1985); they identified 12 types of marks from 19 sites. Based on these marks they assumed ceramic workshops at Staré Hradisko as well as in Milovice and other sites. Almost ten years later the list was updated to 32 sites to include newly identified marks (Čižmár 1995). Marks at the bottom can only be found at late La Tène sites. In our region, this type of ceramics has been found at Ptení (Čižmář 1995, 113, Fig. 4: 12) and Rychtářov (Čižmář - Čižmář - Režný 2015, Fig. 9: 15) where the mark resembles the type possibly produced at Staré Hradisko.

\subsubsection{Typological traits common to LT C2 (Němčice) and LT D1 (Staré Hradisko)}

In this section, only partly time-sensitive elements found on the ceramics are presented. In the study, they are used as a supporting criterion for the evaluation of the assemblages.

Situlae - the basic difference between the ceramic production of situlae in LT B1-C2 and LT C2-D1 consists of the profile of situla-shaped vessels. While during the middle La Tène period the rims are exclusively rounded to be almost circular (Fig. 11:4-6), during the late La Tène period also thinner and in-turned rims routinely occurred (Fig. 11: 24, 27, 30, 32).

Vertical combing - vertical combing is the most common outside decoration. This type of surface treatment is mostly present on situla-shaped vessels; however, it is not particularly time-sensitive. It appears throughout most of LT B-D (Čižmář 1984, 476; Meduna 1980a, 66, 103). However, certain chronological trends can be ob- served. During LT B-C1 we see mostly regular vertical combing on the graphite situlae, often accompanied by the C-shaped stamps (Fig. 11:2, 11). The stamps do not occur later than LT C1 (Hlava 2008, 218; Poulová 2011, 221-224). Also, starting in LT C1 we can observe a general trend at Moravian settlements consisting of the more free-hand execution of the vertical grooves. In addition to the still-dominant regular combing, irregular grooves or separated groups of combings (Fig. 11:27, $28,30,32$ ) are becoming more frequent; sometimes at an angle and sometimes even horizontally. This type of decoration was gradually becoming common on non-graphite coarse vessels as well. Since LT C2 horizontal polished stripes began to appear which went across the regular vertical grooves. From LT $\mathrm{C} 1$ the width of grooves changed from 1.5-2.5 mm (Fig. 11: 11) to 2.5$4 \mathrm{~mm}$ (Fig. 11: 29). Most of the significant changes to the surface of vessels start to occur as early as LT C1. Late La Tène fine ceramics found at the oppidum also sometimes features fine vertical combing (Ženožičková 2011 ,68), but this type of decoration has not yet been identified at the settlements in the region.

Horizontal wavelet decoration (Fig. 11:20, 21) - decoration in the form of horizontal wavelets is commonly found on fine wheel-turned material, already in $\mathrm{Me}$ duna's settlement horizon 4 dated to LT C1 (Meduna 1980a, Taf. 19: 12; 20: 14). This type of decoration is much more common later during the late La Tène period, typically on the inside of s-shaped bowls or the outside of bottle-shaped vessels (Čižmář 1984, 479; Koutecký - Venclová 1979, 96). This type of decoration was found at eight sites in the region, all of which date to LT D1. A production site with an identified pottery kiln was possibly located at Ptení (Čižmář - Hlava Šmid 2005). Chronological position of this decoration is confirmed by its appearance on bowls and vase-shaped vessels (Meduna 1970b, Taf. 40: 17, 20; 45: 16) at Staré Hradisko.

Sickle-shaped rims (Fig. 11:30) - vessels with long, narrow and in-turned rims represent a relatively late feature on La Tène ceramics. Their classification was proposed by J. Meduna due to frequent finds at the Staré Hradisko (Meduna 1970a, 45-46; 1970b, Taf. 42: 1-16; 1980a, 71). M. Hlava confirmed this dating based on finds from Vyškov (Hlava 2002a, 319; Horálková 1993, 479, Fig. 6: 1, 5, 6). However, also at Němčice, several pieces were found, featuring this type of rim (Čižmář - Kolníková 2006, 267). ${ }^{11}$ It may either account for the existence of the site also in LT D1, or the dating of this element is earlier, starting already in LT C2.

Rims with an upper groove (Fig. 11: 29) - relatively late features also include rims with an upper groove. Their increased presence was recorded at Staré Hradisko (e.g. Meduna 1970b, Taf. 28; 29: 23; 37: 1), how-

${ }^{11}$ Brief evaluation and graphic material for the ceramic assemblage from Němčice by M. Hlava (2006) is in the unpublished report from the project number 404/04/0118 'Nové laténské výrobní a obchodní centrum na Moravě' of the Czech Science Foundation (GA ČR). 


\section{LT B-C}
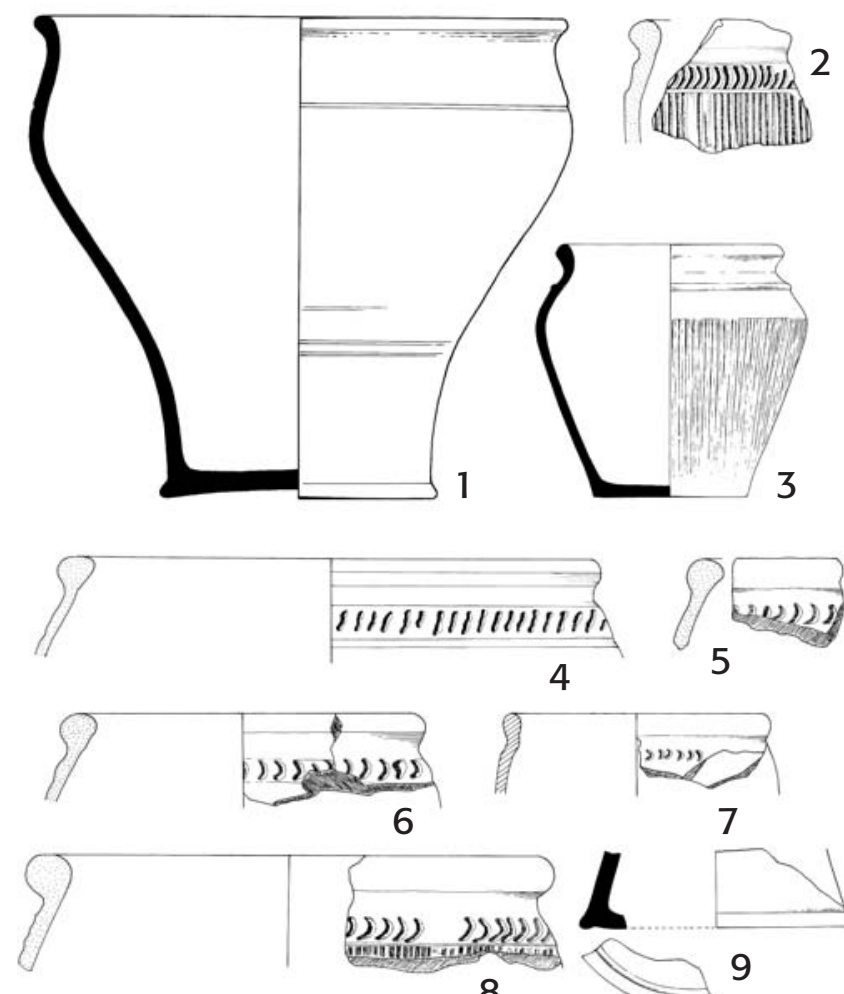

8
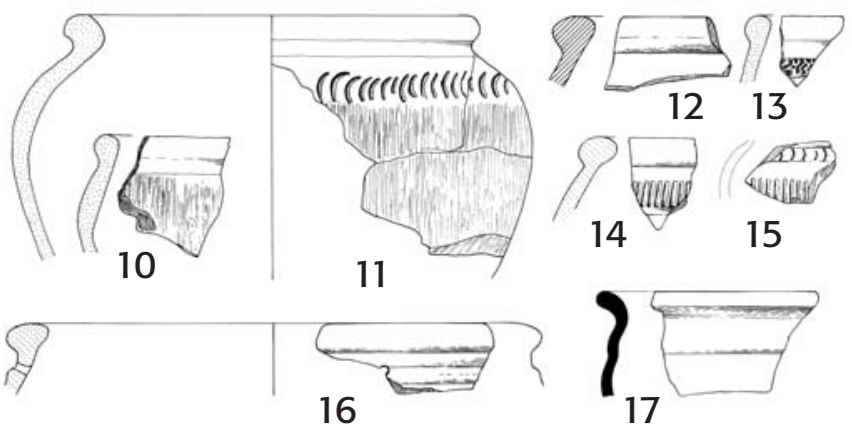

7
LT (end of) C2-D1
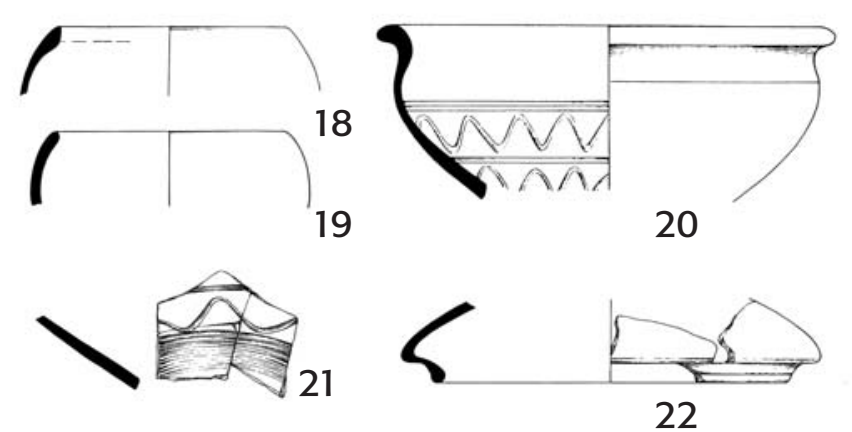

22
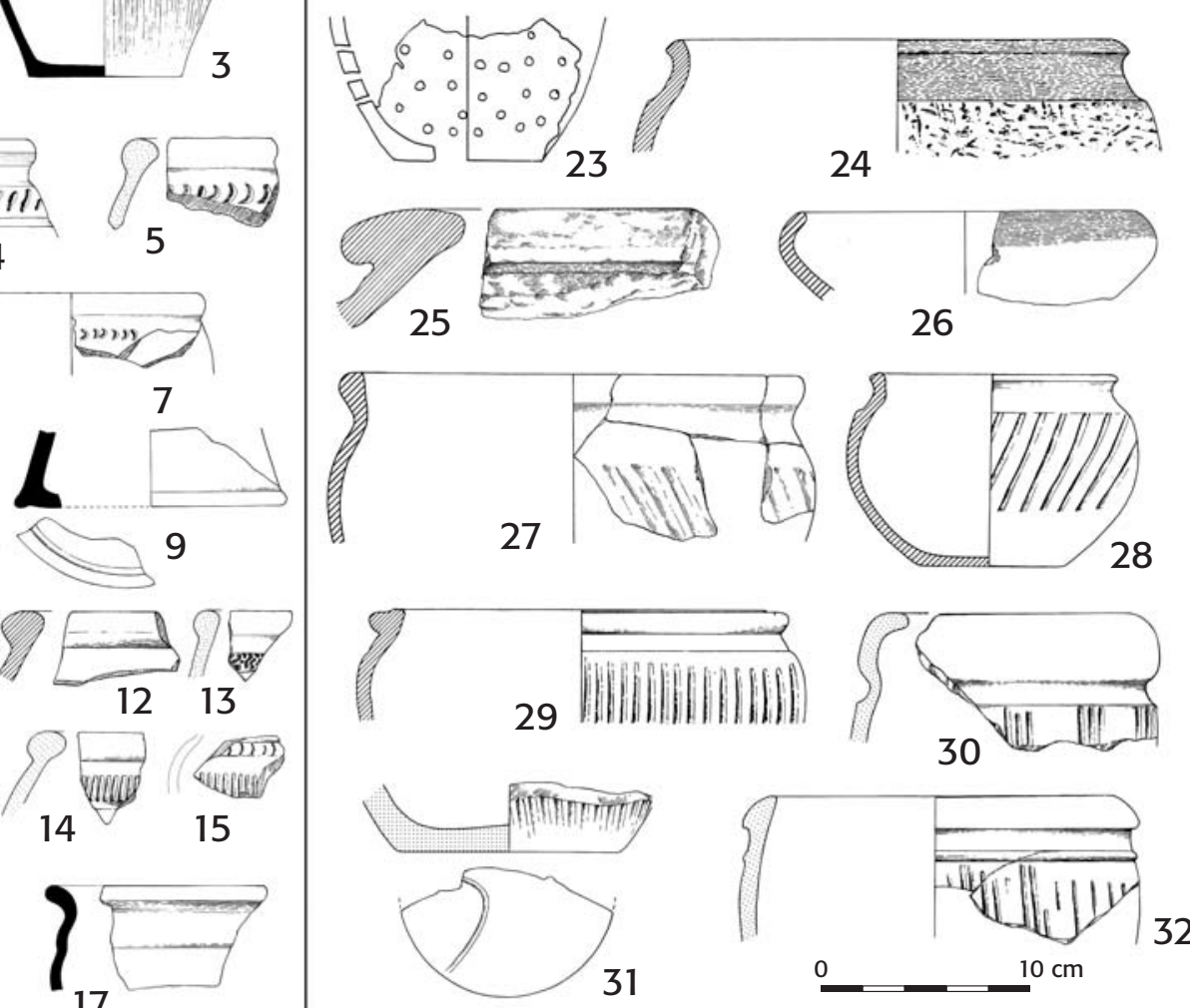

Fig. 11. Comparison of typical ceramic features of the middle and late La Tène period (drawings by A. Krechlerová). - Obr. 11. Porovnání typických znaků na keramice středni/mladší a pozdní doby laténské (kresba A. Krechlerová).

ever, they appear also at Němčice. This, similarly to previous case, either makes their appearance earlier than expected, or may evidence the longer occupation of Němčice. Beside that, all other cases from the region come from settlements dated to LT C2-D1.

Strainers/cencers (Fig. 11:23) - not so common item at La Tène settlements: perforated vessels with a hole in the middle. The term strainer does not seem accurate; the vessels have a hole in the bottom and they were probably used as lids with smoke vents or as regulators of heat or air circulation (Valentová 2013, 6566, tab. 49: 104853). The presence of these lids is limited to the late La Tène period. We can mention two fragments from Ptení (Čižmář 2006, tab. 11: 2, 3; 26: 6); a fragment of the bottom with the hole was found in Rychtářov (Čižmář - Čižmář - Režný 2015, Fig. 6: 11); several fragments come from other late La Tène settle- ments (Čižmář 2003, tab. 50: 2, 3; 54: 5; 56: 2; 93: 9, 10; Meduna 1980a, 96, Taf. 7: 15; 27: 26; 70: 12; 116 : 6; 118: 9).

As pointed out already, the dating of La Tène settlements based solely on pottery is often problematic. LT C2 and LT D1 share some of the common pottery traits. As a result, there is a problem to identify sole LT C2 phase, which would suggest that the site was contemporary (only) with the central agglomeration of Němčice, much less to be able to divide LT C2 into subphases contemporary with either of the two major agglomerations. In such a case there is no other option than to focus strictly on finds, if present, that are typical for LT D1 (e.g. brooches). What can be concluded with a relative certainty is, that the appearance or rather a concentration of traits typical for LT C2-D1 horizon seems to make the site contemporary rather to Staré Hradisko than to Němčice. 

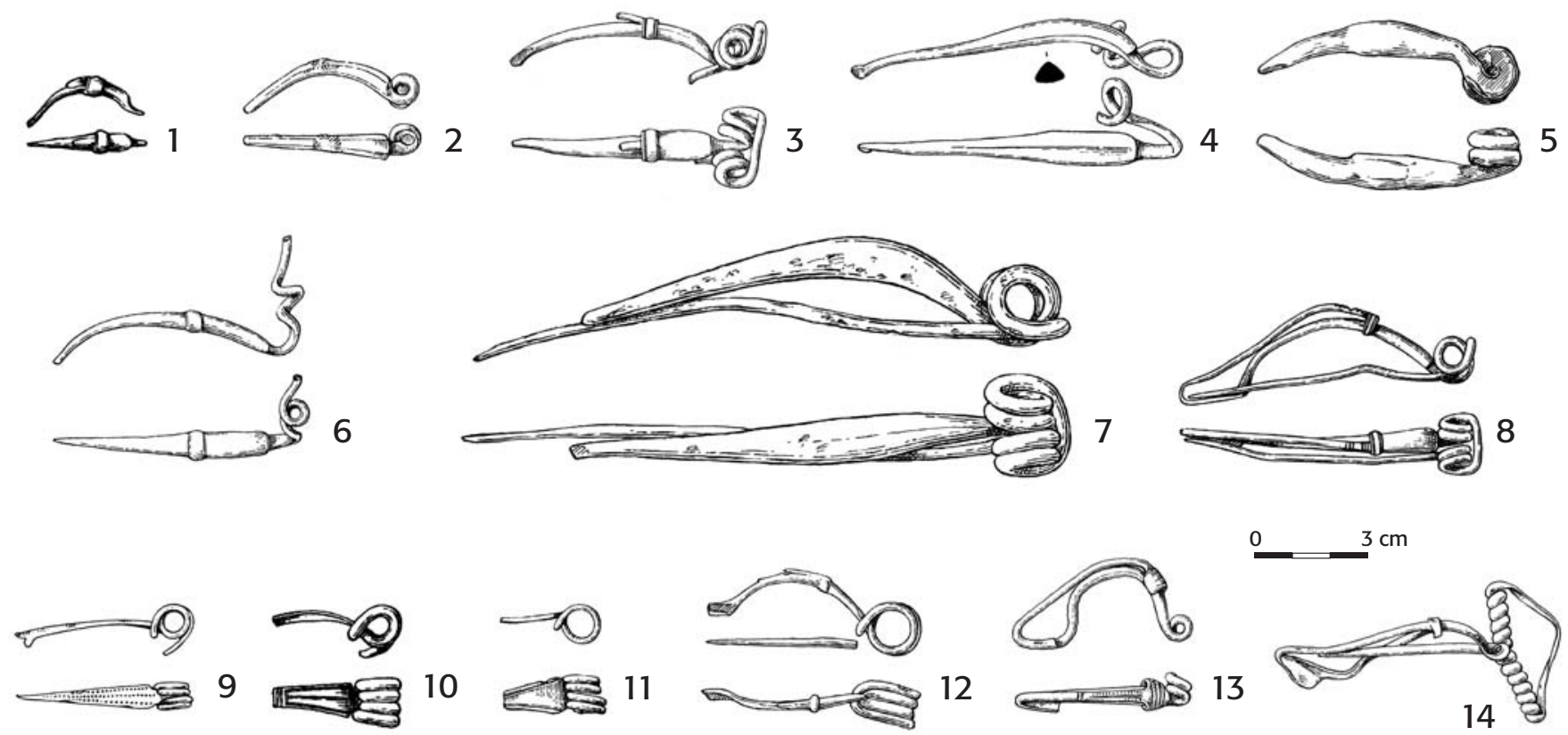

Fig. 12. Brooches characteristic of $L T C 2-D 1$ settlements in the study area: $\mathbf{1}$ - Ivaň; 2, 5, 11 - Klenovice; 3, 8 - Polkovice; $\mathbf{4}, \mathbf{6}-$ Hrubčice; 7 - Stínava; 9 Ohrozim; 10 - Pustiměř; 12 - Rychtářov; 13, 14 -Détkovice (drawings by A. Krechlerová). - Obr. 12. Spony typické pro sídliště z období stupně LT C2-D 1 ze sledovaného regionu: $\mathbf{1}$ - Ivaň; 2, 5, 11 - Klenovice; 3, 8 - Polkovice; 4, 6 - Hrubčice; $\mathbf{7}$ - Stínava; 9 - Ohrozim; 10 - Pustiměr̆; 12 - Rychtáŕov; 13, 14 Dètkovice (kresba A. Krechlerová).

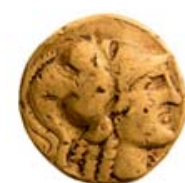

1
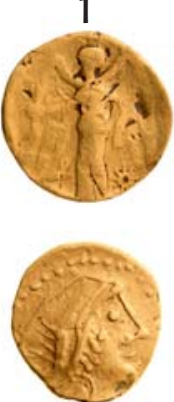

11
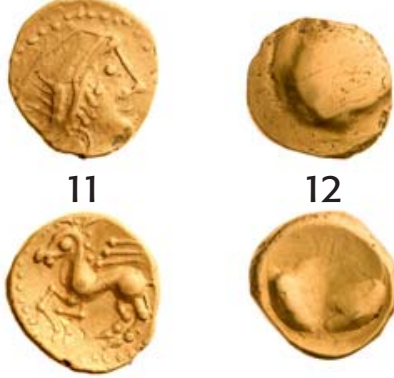

12

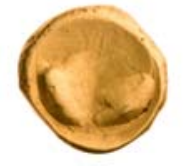

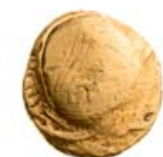

13

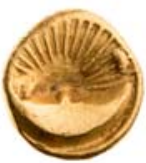

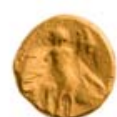

4
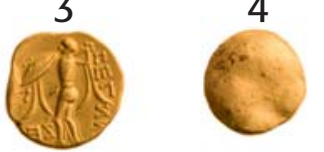

5
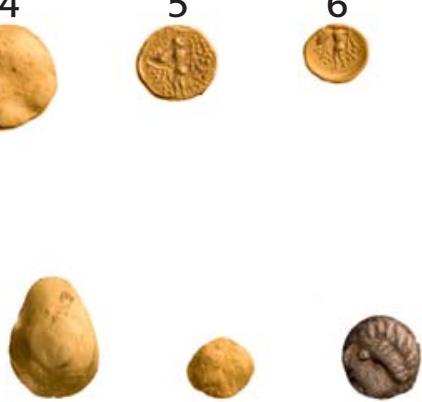

14

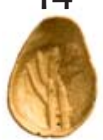

15

16

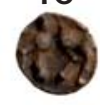

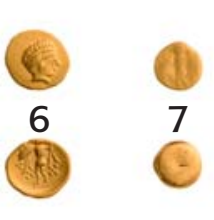
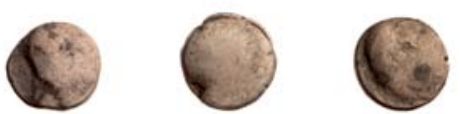

8

9

10
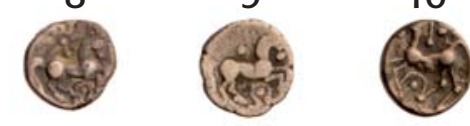

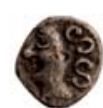

17

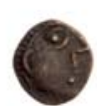

18

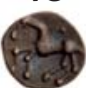

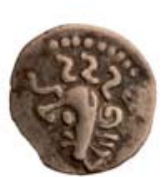

19

Fig. 13. Selection of the basic types of gold and silver coins from lowland settlements in the study area: 1-10 - Němčice horizon; 11-19 - Staré Hradisko horizon. 1 - stater, type Athena/Niké, Němčice, without localization; 2 - 1/3-stater, type Athena's head / running horse and a cross, Polkovice; $\mathbf{3}$ - 1/3-stater, type Athena Alkidemos, Klenovice; 4 - 1/3-stater, type Athena Alkidemos, Ivaň; 5 - 1/8-stater, type Athena Alkidemos, Hrubčice; 6 - 1/24-stater, type Athena Alkidemos, Klenovice; $\mathbf{7}$ - 1/24-stater, type Athena Alkidemos, Ivaň; 8 - silver obol, type with a star, Klenovice; $\mathbf{9}$ - silver obol, type Roseldorf / Němčice I with lyre, Polkovice; 10 - silver obol, type Roseldorf / Němčice Il with lyre, Hrubčice; 11 - stater, type with Pegasus, Pteni; 12 - stater, type with a hump, Hrubčice; 13 - Boian shell stater, Otaslavice; 14 - 1/8-stater, type with an abstract symbolism, Hrubčice; 15 - 1/24-stater, type with an abstract symbolism, Klenovice; 16 - silver obol, type Staré Hradisko E1, Polkovice; 17 - silver obol, type Staré Hradisko D with head with an S-shaped hairstyle, Klenovice; 18 - silver obol, type Staré Hradisko with a stylized head, Klenovice; 19 - silver obol, type Pollanten, Klenovice. Scale 1:1. Photo by ABALON, s. r. o. Provided by Moravian Museum - Institute of Archaeology and Department of Numismatics. - Obr. 13. Výběr základních typů zlatých a střibrných mincí z nižinných sídlišt' ve sledovaném regionu: 1-10 - horizont Němčice; $11-19$ - horizont Staré Hradisko. 1 - statér, typ Athéna/Niké, Němčice, bez lokalizace; 2 - 1/3 statéru, typ hlava Athény / běžící kůň s křížem, Polkovice; 3 - 1/3 statéru, typ Athéna Alkidemos, Klenovice; 4 - 1/3 statéru, typ Athéna Alkidemos, Ivaň; 5 - 1/8 statéru, typ Athéna Alkidemos, Hrubčice; 6 - 1/24 statéru, typ Athéna Alkidemos, Klenovice; 7 - 1/24 statéru, typ Athéna Alkidemos, Ivaň; $\boldsymbol{8}$ - stříbrný obol, typ s hvězdou, Klenovice; $\mathbf{9}$ - střibrný obol, typ Roseldorf / Němčice I s lyrou, Polkovice; 10 - střibrný obol, typ Roseldorf / Němčice II s lyrou, Hrubčice; 11 - statér, typ s Pegasem, Ptení; 12 - statér, typ s hrbolem, Hrubčice; 13 - mušlový statér, Otaslavice; 14 - $1 / 8$ statéru, typ s abstraktní symbolikou, Hrubčice; 15 - 1/24 statéru, typ s abstraktní symbolikou, Klenovice; 16 - střibrný obol, typ Staré Hradisko El, Polkovice; 17 - stř́brný obol, typ Staré Hradisko D s hlavou s esovitým účesem, Klenovice; 18 - stríbrný obol, typ Staré Hradisko se stylizovanou hlavou, Klenovice; 19 - střibrný obol, typ Pollanten, Klenovice. Měrítko 1 : 1. Foto ABALON, s. r. o. Poskytlo Moravské zemské muzeum - Archeologický ústav a Numismatické oddělení. 
Remaining categories of finds, especially metals, apart from brooches, belts etc. (e.g. cast rings with spouts, spoked-ring amulets, decorative nails or rivets, small figural art), may fall within the period of existence of both central places, and their chronological analysis may require the detailed assessment of frequency in order to be possible to attribute them to either of the chronological phases (i.e. LT C2 or D1). It can be demonstrated on glass bracelets from Němčice where most types date to LT C2. To a lesser extent, these bracelets can be also found at the oppidum of Staré Hradisko (Venclová 2016, Fig. 88), where they may characterise its LT C2 phase. Therefore, these categories of finds may only help to illustrate the overall character of the material from settlements occupied from LT C2.

\subsection{Evaluation of continuity of specialised production and organisation of long-distance contacts}

Both the area and period in question stand out due to the opportunity it gives us to analyse the development of specialised production in the agglomerations along the long-distance routes, which allowed for the effective movement of raw materials. Since the third century BC, we can see a massive intensification of the processing of precious metals (gold, silver), copper alloys and glass (Čižmář - Kolníková - Noeske 2008; Venclová 2016). The understanding of trends in the use of these raw materials and the movement of products can be symptomatic of the development of settlement structure in the region, especially from the perspective of the chronology of settlements.

The key question is the continuity between the middle (LT B1-C2) and late (LT C2-D1) La Tène period, which could be reflected in the organisation of the long-distance contacts and the specialised production, in particular raw materials extraction and circulation. As for glass, a change in the sources of the raw material was already pointed out concerning the glass objects produced at Němčice and Staré Hradisko, respectively, that had roots in the source region - the Near East (Venclová 2016).

The issue of the origin of gold for the production of gold coins is not yet sufficiently explained by the scientific data, but arguments exist supporting the theory of local (i.e. central European) sources at least in the late La Tène period (Militký 2015; 2018).

The origin of silver for the increasing production of Němčice/Roseldorf silver obols, followed by obols minted at Staré Hradisko, has yet to be clarified, which is also the case of the transport of raw materials from the place of their extraction (as proposed by J. Militký /2015/, based on the finds of silver ingots), or separate origins of silver and lead used for its purification - the cupellation (cf. Pernicka 2014; 2017).

As for the provenance studies of raw materials and the analysis of trends in the specialised production, the greatest perspective at the moment lies in the copper alloys. Numerous products of the workshops in Němčice (Čižmár̆ - Kolníková - Noeske 2008), combined with the review of the workshops at Staré Hradisko (Danielisová
2014), offer the almost complete chaîne opératoire, allowing to answer the question of the continuity of production using the scientific data.

Analyses of copper alloys are traditionally carried out via combination of analyses of the chemical composition (giving us main, minor and trace elements) and the lead isotopic ratios. Out of chemical elements, those which survive metallurgical processes are most suitable as they can still carry information on the origin of the material (Pernicka 2014, 252-255). Classification of the elemental combinations into material groups form the basis for provenance studies; this way thousands of data has been obtained in Europe (Pernicka 2014; Radivojević et al. 2019; Frána et al. 1995; 1997). The assessment of lead isotopic ratios complements the classification of material groups using the chemical composition analyses. Lead isotopes used for analyses are ${ }^{204} \mathrm{~Pb}$, ${ }^{206} \mathrm{~Pb},{ }^{207} \mathrm{~Pb}$ and ${ }^{208} \mathrm{~Pb}$ (Pernicka 2014, 247). The analysis is usually performed using an inductively coupled plasma mass spectrometry (MC-ICP-MS) and thermal ionization mass spectrometry (TIMS; Niederschlag et al. 2003, 64-67).

The assessment of lead isotopic ratios is a suitable method for the provenance studies, as these ratios remain unchanged during the smelting and other pyrotechnological processes. The geochemical information thus would be the same in the ore and the artefacts. Since the lead isotopic ratios depend on the age of the deposit, various deposits may show different ratios, which makes the identification easier (Ottaway 1994, 161). But it depends on particular conditions and deposit - large deposits may have variable ratios and, on the contrary, deposits of the geologically same age in various regions may show identical ratios. Another problematic issue is the mixing of raw materials from different deposits due to alloying with different materials (lead is the case from the third century BC onwards) or recycling. On the other hand, it has always been the case that the procurement of the raw materials for the production of metals, or copper alloys, in this case, followed certain trends specific to a period, region or a location (Pernicka 2014, 257). Essentially, the more organised system of specialised production, the more targeted and complex was the use of raw sources. To determine whether a certain artefact (made from a copper alloy) comes from a certain source of ore, we need to compare its lead isotopes and chemical composition with the available geochemical data from the deposits, and to assess archaeological and metallurgical data from the region. This way we can exclude deposits which were likely not exploited, or there could not be a connection between them and the analysed objects.

As for the period in question, from the third century $\mathrm{BC}$, lead alloying is becoming typical as it improved the technical properties of the cast. Variability among alloys was not particularly significant; the tin bronze and leaded bronze were the prevailing types of materials. Since LT B2 the production was concentrated in Němčice and, to a lesser extent, in agglomerations (A2 type of sites) along the Valová River. Mediterranean copperalloy objects, except the bronze coins, have yet not been imported to sites along the Amber Road. 

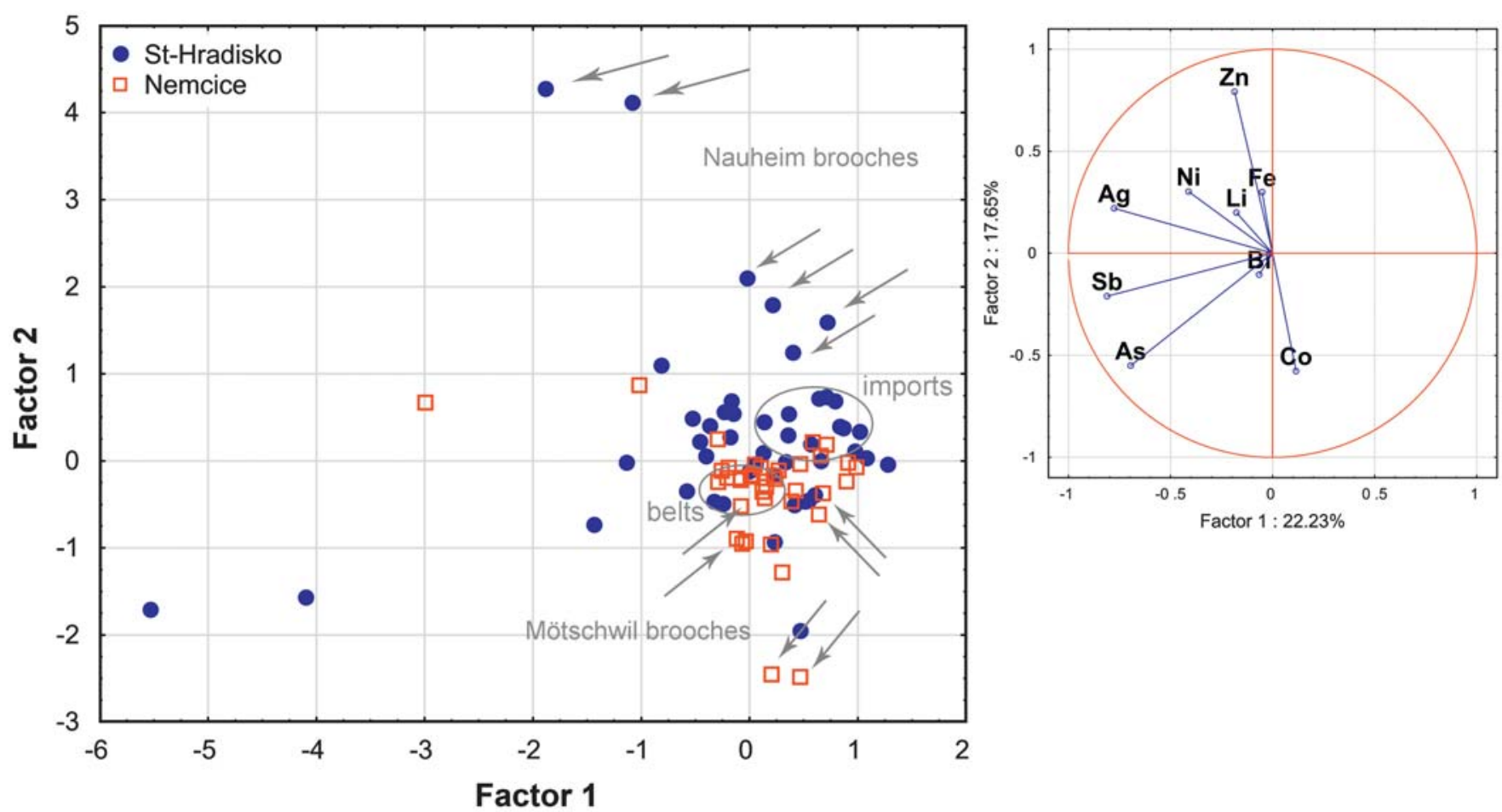

Fig. 14. Principal Component Analysis comparing bronze finds from Němčice and Staré Hradisko. Different combination of trace elements confirms different trends in local production (author A. Danielisová). - Obr. 14. Analýza hlavních komponent porovnávajicí bronzové nálezy z Němčic a Starého Hradiska. Kombinace stopových prvků ukazují na odlišné trendy v lokální výrobě (autor A. Danielisová).

During the existence of Staré Hradisko, i.e. since LT C2, we can already see an increase of the various types of alloys: from the tin bronze with various concentrations of tin, heavily leaded bronze and increased occurrence of antimony alloys, to the earliest occurrence of brass in LT D1b (Danielisová 2020). Also the type spectrum of the objects increased, now numbering the local production and the Mediterranean imports, both including numerous types of objects.

While during the middle La Tène period (when production was organised mainly from Němčice) local production of jewellery and figural art is mostly documented - brooches (Mötschwil), bracelets, small animal sculptures and especially the belts, during the late La Tène period these items included Nauheim brooches, pendants, rivets and amulets. Imports during the middle La Tène period are represented solely by the bronze coins from the Mediterranean (Čižmář - Kolníková Noeske 2008; Kolníková 2012; Kysela 2017; Danielisová 2020). During the late La Tène period, once the centre of production had moved to Staré Hradisko, bronze coins nearly disappeared but new categories of import appeared: heavily leaded bronze vessels with the origin in northern Italy, mirrors, surgical tools and other bronze items (Kysela 2020).

Comparison of the bronze assemblages from the middle and late La Tène period can answer the question of whether continuity existed regarding the production at the two centres. In case the same raw materials were used and Mediterranean imports were coming from the same area, it would suggest the assumption of the role of Němčice by Staré Hradisko not only in terms of political and social influence, but also of its economic strate- gies. The chronological continuity of coins was pointed out already (Hiriart et al. 2020), while there is practically none in terms of glass (Venclová 2016), which, however, does not have to suggest disruption of established trade contacts and organisation of specialised production, at least not from the side of central European recipients of the raw materials.

Two sets of artefacts (50 samples each) were used to assess aspects of specialised production of copper alloys, from Němčice and Staré Hradisko, and to possibly answer the question of continuity in the bronze production. Chemical composition analysis was carried out, as was lead isotope analysis. The trace element patterns were compared using the Principal Component Analysis (Fig. 14). ${ }^{12}$ The local (as of in the region ) fabrication is evidenced by a characteristic pattern of geochemical data, both the trace elements and also lead isotopes. In the available datasets we should be able to distinguish groups with similar geochemical properties, that could account for their origin in the same workshop, or, at least, the same source of raw materials used for their fabrication. The results showed that the composition at each site overlaps only partially and does not suggest the use of identical materials for the fabrication of chronologically sensitive objects - especially the Mötschwil and Nauheim brooches and belts.

Lead isotopic data (Fig. 15) further confirm these findings in that they emphasise different trends in the use of raw materials in Nermčice and Staré Hradisko.

\footnotetext{
12 The methodology is described in detail in Danielisová et al. 2021; Danielisová et al. in print.
} 
Fig. 15. Lead isotopic ratios from Moravian burial grounds contemporary with Němčice nad Hanou, Staré Hradisko and imported Mediterranean bronze coins found in Němčice. The results show a dispersion of values in the case of the burial grounds and Nermčice and, on the contrary, the strikingly more homogeneous sources in the case of Staré Hradisko and the Mediterranean coins. Variations of the symbols in the legend: grey (circles) - belts from Němčice; black (including black filling) - Mötschwil type brooches; red filling - imports at Staré Hradisko; green filling - Nauheim type brooches (author A. Danielisová). - Obr. 15. Analýzy izotopú olova z moravských pohřebišt' ve srovnání s nálezy z Němčic, Starého Hradiska a mincemi mediteránního pưvodu z Němčic. Výsledky ukazuji rozptýlené zdroje v prípadě pohrebišt' a Němčic a naopak koncentrované hodnoty $v$ prípadě Starého Hradiska a mediterránních mincí naznačující zmènu v organizaci výroby se zacílením na konkrétní zdroje. Šedá kolečka - opasky z Němčic; černé symboly (včetně černé výplně) - mötschwilské spony; červená výplň importy na Starém Hradisku; zelená výplň spony typu Nauheim (autor A. Danielisová).

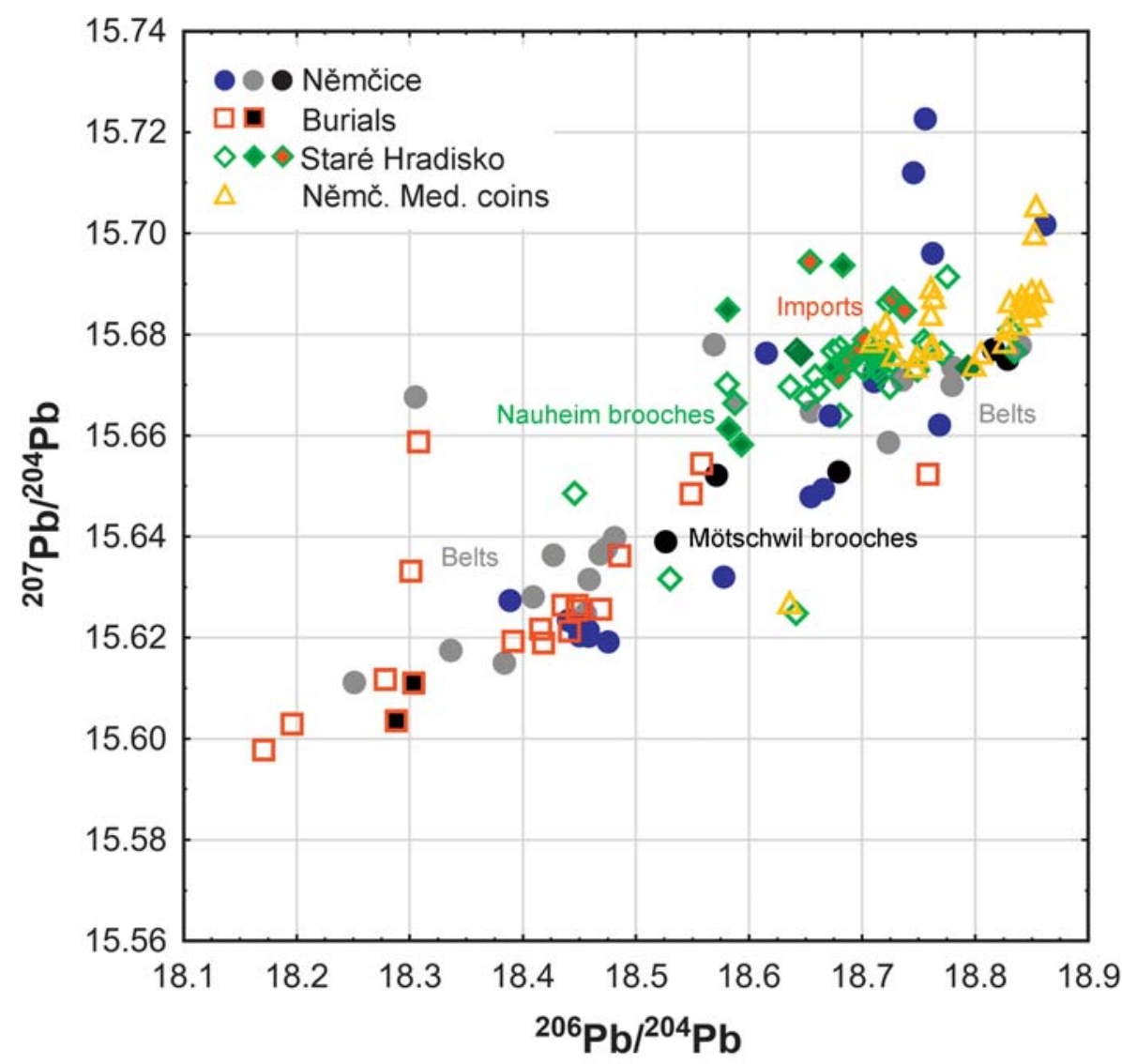

Němčice shows a greater variety of values which would normally mean a greater variety of sources. Raw materials used in Němčice partially overlap with the inventory of analysed contemporary burial grounds in the region (i.e. LT B2-C1), which may suggest the same origin of raw materials as in the case of Němčice workshops or a direct origin of the burial inventory at Němčice. Compare to the dispersion of values typical for middle La Tène period, the production at the oppidum seems concentrated and conforms to a certain extent to sources of imported bronze from the Mediterranean. The issue of recycling of bronzes imported from Northern Italy where lead coming from southeast Spain was processed (Danielisová 2020, 125-127) is only suggested; it is evident, however, that specialised production of the copper alloys during the late La Tène period follows significantly different spectrum of raw materials. It probably indicates that the sourcing of the materials was more advanced than in the previous period, using only limited number of sources. It can indicate also more widespread or intensive recycling that homogenised the geochemical pattern of the data. Nevertheless, there were certain differences observed in the case of data from Staré Hradisko, that allowed for distinguishing between the assumed local production (brooches, rivets, beads etc.) from the Mediterranean imports (bronze vessels).

It should be emphasised, however, that unlike geochemically largely investigated sources in the Mediterranean (Artioli et al. 2020) data on local sources of copper is practically nonexistent. The position of sites and long-distance routes suggest the use of sources of copper and other metals along the Moravian Gate (Fig. 22). But we can safely assume that there was no continuity between the central agglomerations concerning the organisation of specialised production and long-distance contacts focused on the raw materials for producing the copper alloys.

\section{Results - characteristics of settlements in the region of central Moravia}

Based on the analysis of settlements and their chronology, it is apparent that, in accordance with the situation observed in the eastern part of the central Europe, the greatest development of settlements in the region occurred during the middle La Tène period, i.e. stages LT B2-C2 (see also Danielisová 2020, 138-144). Settlements from this period are located in the fertile lowlands of Haná at elevations rarely exceeding $250 \mathrm{~m}$ (Fig. 18-19). Besides this concentration of sites, numerous settlements were located also along the Morava River. Furthermore, settlements followed the courses of other smaller rivers, such as Blata, Haná and Valová. We can assume that natural communication routes existed here (Fig. 17).

The central site was the agglomeration in Němčice. It was located on the main communication route connecting the Baltic Sea with the Mediterranean along the corridor Roseldorf - Němčice - Nowa Cerekwia. Judging by finds from this agglomeration and nearby settlements, connections existed especially within the Middle 


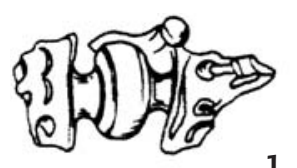

1

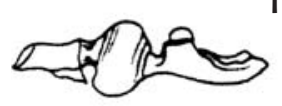

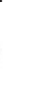
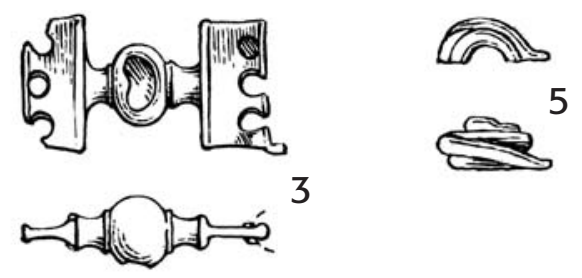

3 5

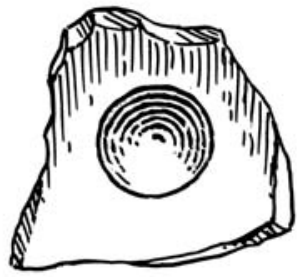

Fig. 16. Finds from the lowland sites of the type A2 (cf. chapter 2.1) with the evidence of specialised activities: $\mathbf{1 - 4}$ - pieces of bronze belts including semi-products: 1 - Hrubčice; $\mathbf{2}, \mathbf{4}$ Polkovice; 3 - Klenovice; 5-6 - glass: 5 - Klopotovice; $\mathbf{6}$ - Mërovice; $\mathbf{7}$ - clay coin mould, Klenovice (drawings by $A$. Krechlerová). Obr. 16. Nálezy z nižinných lokalit typu A2 (viz kapitola 2.1) s doklady výrobnich aktivit: 1-4 - polotovary článkü bronzových opasků: 1 Hrubčice; 2, 4 - Polkovice; 3-Klenovice; 5-6 - sklo: $\mathbf{5}$ - Klopotovice; $\mathbf{6}$ - Měrovice; $\mathbf{7}$ - hliněná mincovní destička, Klenovice (kresba A. Krechlerová).
Danube area (southwestern Slovakia, Lower Austria and the adjacent parts of Hungary), and across Slovenia to Northern Italy (Čižmář - Kolníková - Noeske 2008, 664). As the influence of Němčice was diminishing and especially when the centre moved to the oppidum at Staré Hradisko the population density in the region decreased significantly.

During the late La Tène period, we can observe a major shift in the settlement pattern. Once the central place had moved to Staré Hradisko, there was a significant decrease in the number of rural sites in the lowlands. The reasons for the decrease in occupation lied probably in the depopulation of the region. While during LT B2-C2 we have identified 85 sites, during the late La Tène period the number dropped to only 47 (Fig. 18). Many settlements from the previous period ceased to exist - i.e. there is no evidence of their occupation especially during the LT D1. In relation to the depopulation of the lowlands in Haná, many completely new settlements (23) without the evidence of prior occupation appeared sometime around the end of LT C2 or solely in LT D1. They are located at higher altitudes over $250 \mathrm{~m}$ asl, 10 to 12 kilometres from Staré Hradisko and they form a sort of an inter-connected zone of occupied land around the oppidum (Fig. 18, 20).

As for the lowlands, the continuous occupation to the late La Tène period is recorded along the Valová River, at regular spacing distances over 3 kilometres. This is where we have identified long-term continuous settlements (since LT A) referred to as 'agglomerations' (Fig. 5,18 ). At each of them, the evidence of specialised production was found. They are thought to have flourished especially during LT C2. Based on numerous finds of coins we can assume that they could have been minted there during this period. This could be also supported by the discovery of a clay coin mould in Klenovice (Fig. 16).

The presence of agglomerations (Hrubčice, Klenovice, Polkovice and possibly Smržice) suggest the existence of a natural communication route (cf. chapter 4.2) from the northwest to the southeast along the Valová River. This route has been modelled previously using social simulations - it proved the trend of natural accumulation of (hypothetic) settlements and the formation of agglomerations along natural communication corridors (Fig. 17; Danielisová - Štekerová 2015, 164-165). Going hand in hand with the favourable location is the continuity of occupation as proved since LT A, or the fact that the sites were inhabited also later, during the Roman period.

A similar situation was observed in the Břeclav region along the Dyje River, but in this case the settlements situated along the river are located much closer to one another, and at slightly higher elevations (Čižmár̆ 1992, 71). The sites at the Valová River were also located at slightly higher elevations, some of which are hardly noticeable today due to alluvial processes.

During LT D1 an interesting phenomenon occurred around the Morava River where, surprisingly, no evidence existed of the late La Tène occupation (Fig. 18). Occasional late La Tène settlements separated 6-8 km from one another were found along Blata River where, as we assume, a communication existed towards present-day Mohelnice.

The dominant centre of the late La Tène period was the oppidum of Staré Hradisko, which follows the previous communication network scheme of the central agglomeration at Němčice. However, the typological spectrum of objects and especially their material properties (chemical composition, lead isotopes) point to different strategies for obtaining raw materials for both imported items and the local production, which reflected especially the development of the economic conditions in the Mediterranean. What concerns the local production of ceramics and the distribution of stone rotary querns, Staré Hradisko was a central place of a complex network connecting the oppida in Bohemia, along the Vltava and Elbe communication routes, and the Middle Danube area together with the North-South axis known as the Amber Road from the Adriatic to Baltic area.

New rural settlements (type Al) were usually founded in the proximity to the oppidum at slightly higher altitudes (Fig. 18, 20). In addition to them, other smaller 


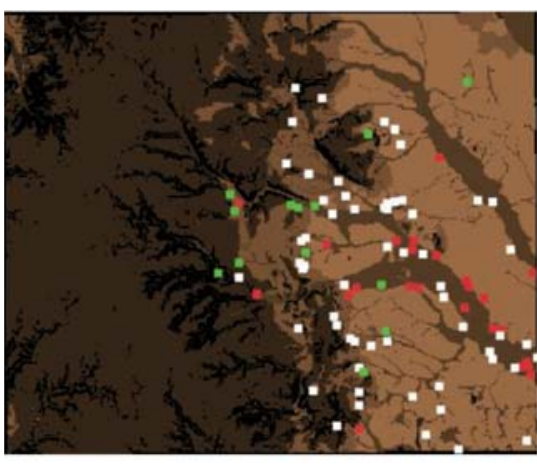

sites $=97$

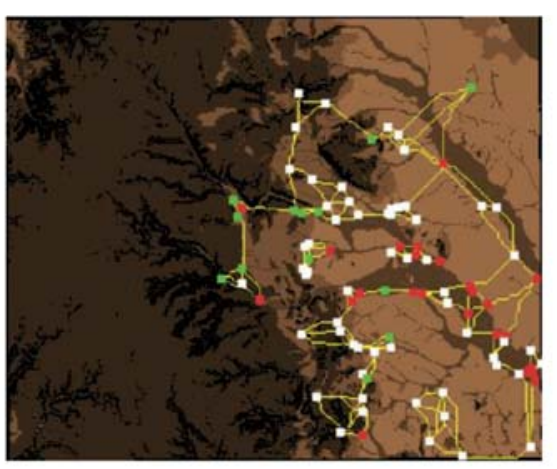

paths initial:

population: 1000

population growth $-2 \%$

settlements: 97

population limit: 30

relative population to move: 0.3

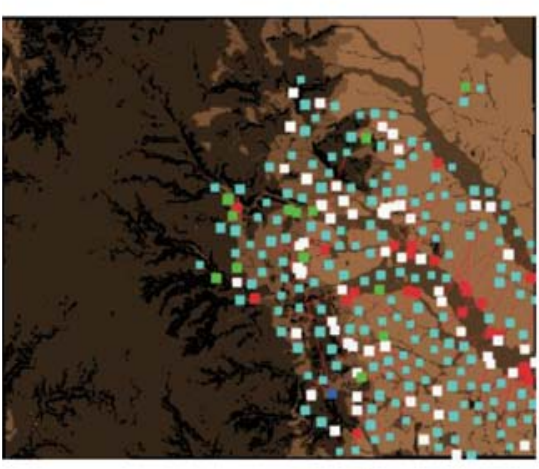

population $=3411$

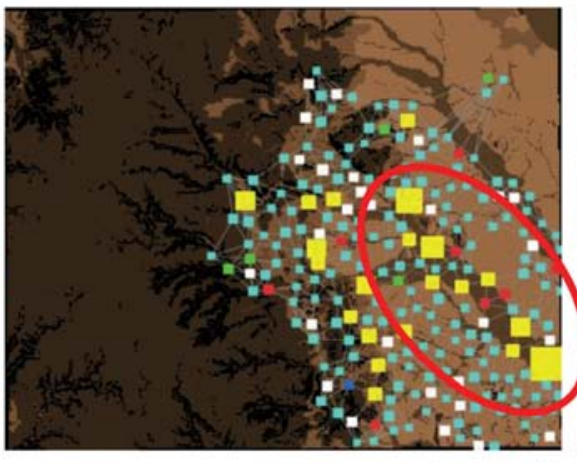

clustered

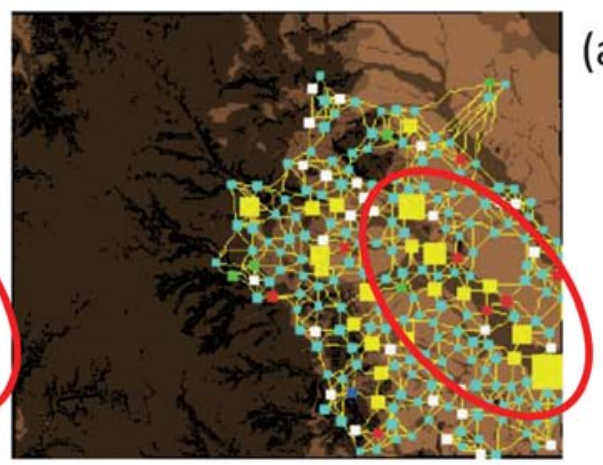

paths

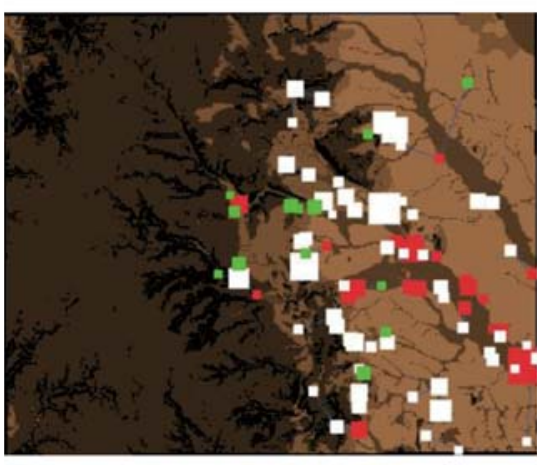

population $=3411$

sites $=97$

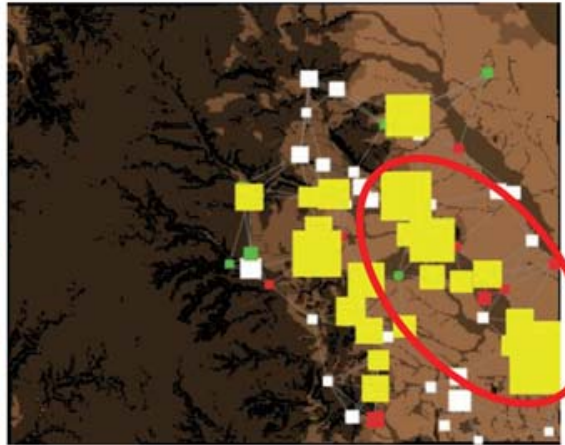

clustered

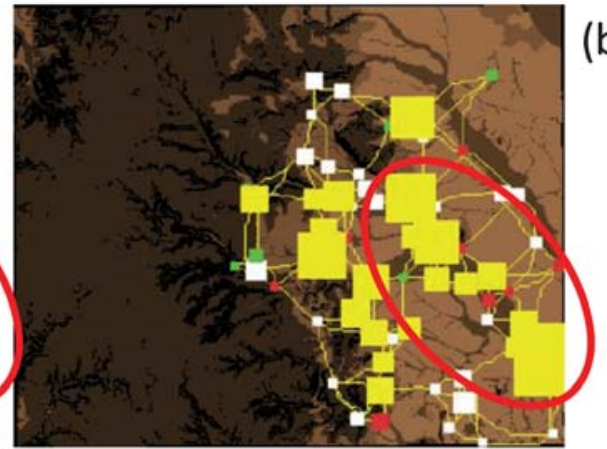

paths

Fig. 17. Results of computer modelling focused on the prediction of settlement network in the study area described in the paper of Danielisová - Štekerová (2015). The model was focused on identification of the most advantageous locations for creations on natural hubs in the settlement network. In other words, a location was to be selected where the natural concentration of settlements (leading to the creation of natural hubs) and most probable communication corridors could be expected. In the time of the creation of the model (2015), the structure of La Tène settlements was not known. The model, created for the initial population of 1000 people, has confirmed the trend towards the accumulation of larger settlements along the River Valová (the area in the red ellipse). This area is ideal for the concentration of occupation thanks to the combination of environmental conditions and natural communication network. In the picture the possible communication routes are marked by yellow lines and places favourable for the concentration of population by yellow squares. The size of the symbols is graduated according to the size of the population (for further details on the model, cf. Danielisová - Štekerová 2015, 162-165). - Obr. 17. Výsledky počítačového modelováni zaměřené na predikci sídelni sítě ve sledované oblasti popsané v příspěvku Danielisová - Štekerová (2015). Model byl zaměřen na identifikaci nejvýhodnějšich terénních poloh pro vytváření prĭrozených komunikačních uzlů v sídelní síti. Jinými slovy, mělo být vybráno místo, kde lze očekávat prirrozenou koncentraci sídel (vedouci k vytváření aglomerací) a nejpravděpodobnějších komunikačních koridorü. v době vytvoření modelu (2015) nebyla známa struktura laténských sídel diskutovaná v této práci. Model vytvořený pro počáteční populaci 1000 lidí potvrdil trend k akumulaci větších sídel podél reky Valové (oblast v červené elipse). Tato oblast je ideálni pro koncentraci osídleni diky kombinaci podmínek prírodniho prostředí a prirrozené komunikačni sítě. Na obrázku jsou možné komunikačni trasy vyznačeny žlutými čarami a mista přrznivá pro koncentraci obyvatel žlutými čtverečky. Velikost symbolů je odstupňována podle velikosti populace (dalši podrobnosti o modelu viz Danielisová - Štekerová 2015, 162-165).

hilltop sites were founded along the edge of Drahany hills, usually with no evidence of fortification. Their interpretation can be based on relation to Staré Hradisko. Even though activity at these sites is confirmed via nu- merous surface finds, it should be noted that continuous occupation (including the evidence of the production of iron brooches) was confirmed only at one of them (Rychtářov, see Čižmář - Čižmář - Režný 2015). It is 



Fig. 19. Comparison of the elevation $(\boldsymbol{A})$ and the soil types $(\boldsymbol{B})$ of the settlements from the middle (Ctype - blue) to late (Al type - red) La Tène period. Shift to higher altitudes and lighter soils (brown soils, kambisols) is apparent (author A. Danielisová). - Obr. 19. Porovnání nadmořské vy̌šky (A) a pưdních typů (B) sídlišt' od střední (modře typ C) do pozdní (červeně typ A1) doby laténské. Posun do vyšších nadmořských výšek s lehčími půdami (hnědozemě, kambizemě) je znatelný (autor A. Danielisová). 

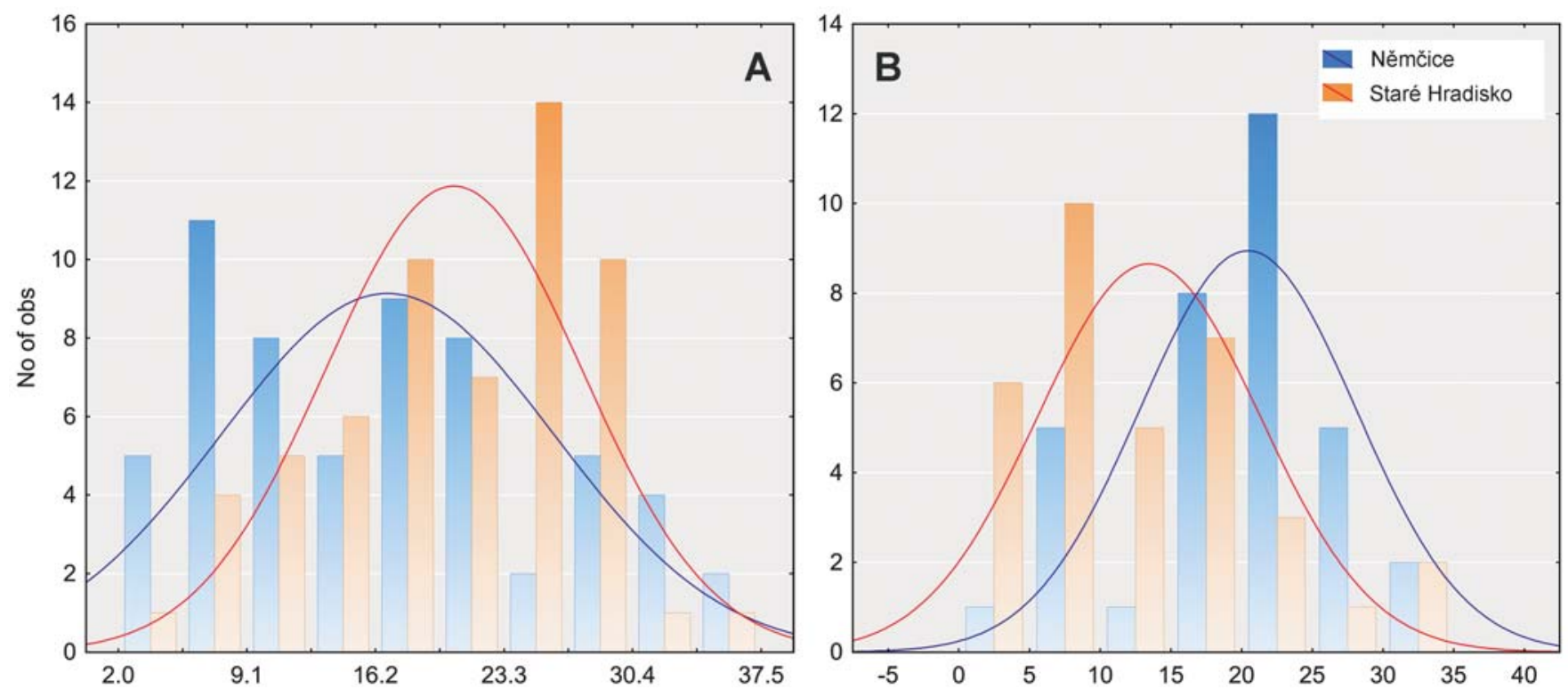

Fig. 20. Comparison of the distances to the central agglomerations (Němčice - blue, Staré Hradisko - red) in the (A) middle (C-sites) to (B) late (A 1-sites) La Tène period. More significant spatial connection to the oppidum is apparent (values in km). Author A. Danielisová. - Obr. 20. Porovnání vzdálenostík centrálním aglomeracím (Němčice - modře, Staré Hradisko - červeně) ve (A) střední (lokality typu C) a (B) pozdní (lokality typu A 1) době laténské. Znatelná je výraznější prostorová vazba s oppidem (hodnoty v km). Autor A. Danielisová.

possible that these were specific sites with a refugial purpose, as we know them from other parts of Europe (e.g. Graff 1963; Nortmann 1991, 127-129, 139-140) and as they have been also recorded in western Bohemia (Waldhauser 1984). The use of higher-altitude areas by 'common people' is not unheard of from other European regions, e.g. the hilly terrain around the Bibracte oppidum in Burgundy (Barral - Nouvel 2012; Moore et al. 2013).

\section{Discussion}

\subsection{Development of the position of central Moravia within the Middle Danube area from the middle to the late La Tène period}

It was already pointed out that the most significant site during the middle La Tène period was the central agglomeration at Němčice, a centre of production and local and long-distance trading networks. We can tell for sure that this agglomeration and settlements within its catchment area were culturally and economically oriented on the Middle Danube area. During this period, especially in LT C2, the central Moravian settlements saw major development, both the central agglomeration at Němčice as well as the 'settlement agglomerations' along the Valová River.

As for the late La Tène settlements in central Moravia, we observe strong ties to eastern and central Bohemia in the form of numerous material evidence coming to the area since the end of LT C2. The oppidum of Staré Hradisko became the social, political and economic centre of the region with the supra-regional influence.

The Staré Hradisko oppidum was still connected to southern regions by organised trade contacts. Among the finds at the oppidum were many objects attributed to the
Roman Republic: Cenisola type fibulae and fragments of bronze vessels originating in the Northern Italy, and the millefiori glass from the Southern Italy (Čižmár $2002 b$, 219-220; Venclová 2016). With the kingdom of Noricum, located mostly on the territory of present-day Austria, evidence of contacts exists from Staré Hradisko in the form of bronze openwork sheets, Almgren 65 brooches (Pieta 1997, 48, Abb. 2: 12, 13, 16, 17), or norico-pannonian belt hooks (Bockius 1991, 284-285, Abb. 2, Liste 1). Contacts between the central European regions with Slovenia were investigated by D. Božič $(1993 ; 1998)$. Evidence includes a great variety of objects, some of which (e.g. bronze buttons with a triskelion, bronze buttons with decorated centres or bronze cogwheels) could have been produced at Staré Hradisko, but their local origin is still unconfirmed (Čižmář 2002b, 220). The spectrum of finds and their material properties (chemical composition, lead isotopes) show different raw materials used for the imported objects and the local production.

During the late La Tène period, the Moravian territory was influenced by several cultural environments. The Púchov culture occupying hilly region of eastern Moravia was strongly influenced by the late La Tène cultural milieu through the commercial contacts since LT C2.

This phenomenon can be evidenced by the unpublished find of an iron ploughshare from Němčice, a typical object for the Carpathian and Middle Danube regions. Most of these ploughshares come from the territory of the Púchov culture (Čižmář 2012b, 139-140) and the find from Němčice can thus be the evidence of its contacts with the La Tène environment. Mutual contacts of the local population with the Púchov culture also took place in the late La Tène period (LT D1), as evidenced by the brooch with a long spring from Dětkovice. Its analogy is known mainly in the area of the Carpathian Basin (Pieta 2008, 57, 60, Fig. 25B), while from Moravia we record finds from the Púchov culture 
from the Štramberk 'Kotouč' or Jičina 'Požaha' hillforts (Čižmár̆ 1990b, Abb. 2: 5, 6; 1993, 94, Abb. 1: 10). Two iron brooches also come from the excavations at Staré Hradisko.

Since LT D1 the La Tène community started to come to closer contacts with the Germanic population due to its increasing presence along the Amber Road corridor. These were mostly representatives of the Przeworsk culture whose burial sites were found in Dolany and perhaps also in Dubany (Meduna 1968, 56-58; Kalábek 1999, 267-268); fragments of Przeworsk pottery were found at the settlement agglomeration in Držovice and possibly in Brodek u Prostějova (Tejral 1968, 508). There are also numerous instances outside the studied region, e.g. Rymice, Pravčice or Vyškov (Meduna 1973; 1980a, 166; Horálková 1993). The earliest example from central Moravia is a ceramic assemblage from the settlement pit in Olomouc where fragments of Przeworsk pottery were found alongside the ceramics dated to LT C1 (C-shaped stamps). ${ }^{13}$ The occasional activity of the Germanic people is therefore assumed to occur as early as during the second century BC. Contacts with northern areas are apparent at Staré Hradisko (Meduna 1968; Čižmář 1996, 368) and possibly at lowland agglomerations as well. This may be indicated by the fact that all agglomerations around the Valová River were occupied during the Roman period (i.e. younger than La Tène), but we do not yet have the direct evidence of the presence of the Przeworsk finds from these sites. On the other hand, most of the material comes from the surface prospections so the possible Germanic finds may not be necessarily identified and interpreted correctly. The question of the interpretation of the burial ground from the late La Tène period with a vessel with faceted-rim from Seč near the Staré Hradisko (Čižmář - Popelka 2020), that was, in contrast to the above-mentioned examples, contemporary with the oppidum, is also unresolved. However, despite the current lack of direct evidence of permanent settlements, based on the current archaeological record the presence of the Przeworsk people in Moravia can be expected.

\subsection{Communication routes}

It has been a long-established fact that the so-called eastern branch of the Amber Road, i.e. the communication route from the Baltic Sea region to Northern Italy (the Adriatic), went through Moravia, with the Moravian Gate being its natural corridor. Upon the demise of the agglomeration at Němčice the communication route continued to be in operation with the nodal point being at the oppidum at Staré Hradisko.

In the Moravian territory, the Amber Road probably went from Silesia, through the region controlled by the Púchov culture with possible 'checkpoints' in the Moravian Gate at Štramberk, Hukvaldy, and Kunovice hillforts. Other checkpoints within the Moravian Gate were established at hilltop La Tène sites (Chvalčov 'Hostýn', Loučka 'Obírka'). The route must have contin-

\footnotetext{
${ }^{13}$ Unpublished assemblage from the Regional Museum in Olomouc (Vlastivědné muzeum v Olomouci), no. 2/99.
}

ued through central Moravia where it would branch into a route towards Staré Hradisko and one towards the south. We can assume it continued along the Hostýn hills, via Napajedla and Dolnomoravský úval, along the Morava River to the confluence with the Danube. The second branch would continue via Vyškov Gate, ultimately connecting the lowlands of Dyjsko-svratecký úval. In the case of the former, the route run close to a significant settlement known as Otrokovice 'Chmelín', as suggested by finds of raw amber that was probably processed here (Parma 2007, 344). In the case of the latter branch, there was another notable late La Tène settlement of Vyškov whose size suggests its importance was similar to that of Otrokovice.

In addition to the aforementioned main route from the north to the south representing the respective section of the Amber Road, other routes of regional significance are thought to have existed in the region. Possibly the most important ones (as confirmed by the abundance of finds) were those connecting eastern and central Bohemia with Malá Haná and central Moravia, with its most important centres at Němčice and later at Staré Hradisko. The most likely scenario was natural communication route from the Ptení agglomeration via the valleys of rivers Romže and Nectava, ultimately connecting Haná and Malá Haná, via the northern part of Lysická sníženina to eastern Bohemia (Fig. 21). The route is confirmed via numerous finds at the Ptení agglomeration which was located at its south-eastern end, as well as the settlement in Chornice at the opposite end (Vich 2017, 636-638, 663). Its existence is further evidenced by the discovery of a gold coin in Dzbel (Meduna 1968, 60-61). Furthermore, it is probably not a coincidence that the unique Ptení hoard was discovered at this route. At the same time, goods originating from Bohemia also had to travel via this communication, such as rotary querns from Kunětická Hora, typical central Bohemian ceramic ware and other products of Bohemian provenance (see Danielisová 2010).

Another, albeit much longer route over Drahany hills, is the communication from Haná to the north, over their eastern slopes and the present-day Mohelnice and then to the west along the river Třebůvka or, 15 more kilometres to the north, the valley of the Moravská Sázava River near the present-day Zábřeh (Vích 2005, 326). However, no La Tène finds have yet been discovered in this area. Besides, considering the location of the oppidum and the sparse La Tène occupation near the present-day Mohelnice, we do not assume these would be significant communication routes during this period.

Regarding the evaluation of the finds from Staré Hradisko and the late La Tène settlement in Bořitov with the evidence of extensive specialised production, we can conclude that these two sites maintained extensive contacts. A communication likely run here which connected Staré Hradisko with Boskovická brázda, despite the condition to cross the hilly area. While there may be no natural corridors in this region, the theory of the route from the oppidum connecting Malá Haná and Haná was there before, thanks to F. Lipka and K. Snětina (Lipka - Snětina 1913, 119-120), even though they had no evidence to support this theory (cf. Böhm $1937,18)$. Today the existence of a communication 
Fig. 21. Map of the settlement structure during LTD 1 with possible communication corridors: black sites of the type Al; white - sites of the type A2 (author A. Danielisová). - Obr. 21. Mapa struktury osídleni v LT DI s možnými komunikačními koridory: černá - lokality typu $A 7_{\text {; }}$ bilá - lokality typu A2 (autor $A$. Danielisová).

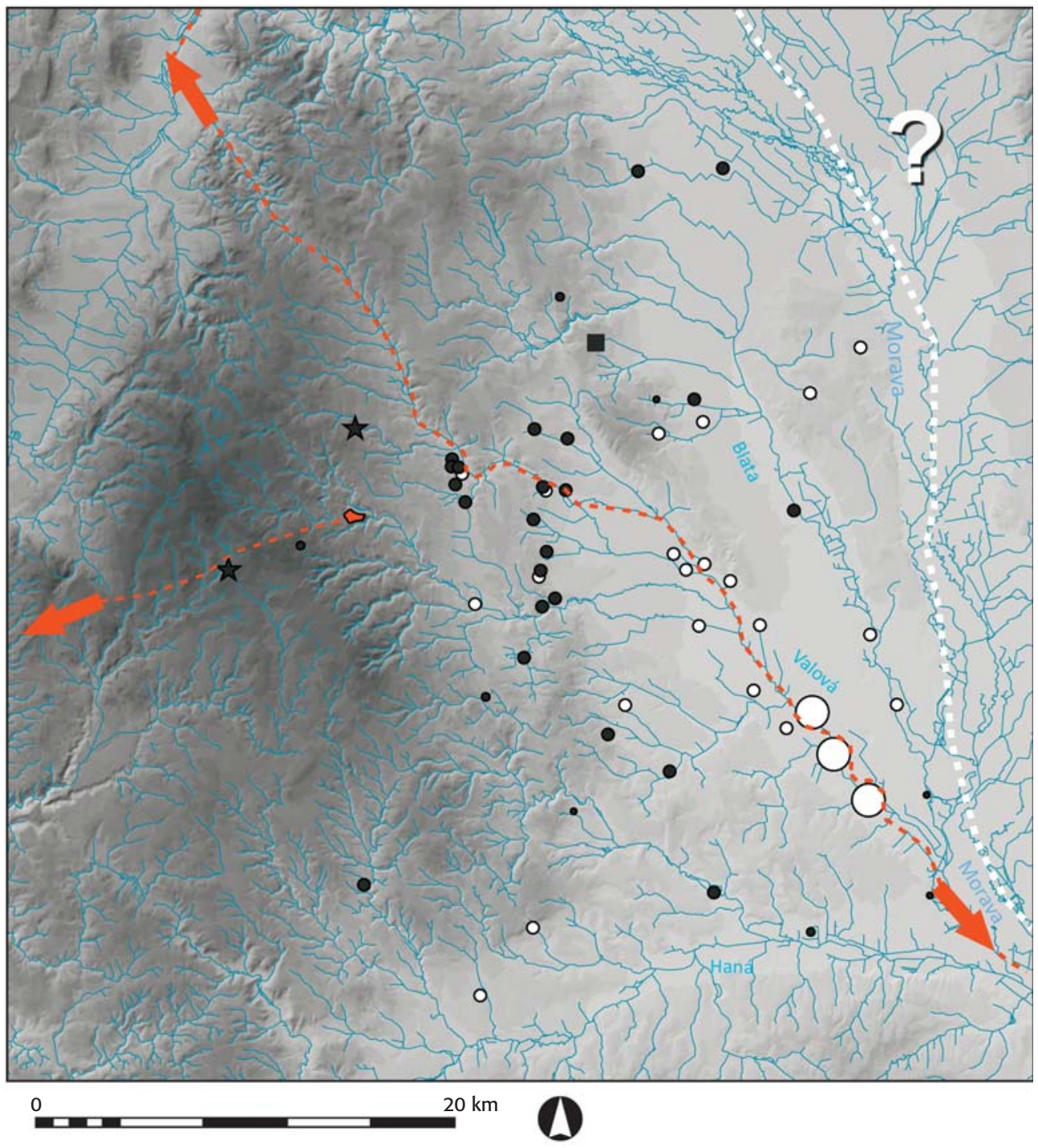

route may be confirmed by several La Tène finds from an area to the west of the oppidum: an isolated find of a bronze ring from the western part of the cadastre area of the village of Male Hradisko, i.e. some $3 \mathrm{~km}$ to the southwest of the oppidum, and two gold staters approximately $7 \mathrm{~km}$ in the same direction near the village of Protivanov. Another isolated find was made to the west of the oppidum: a piece from a bronze belt dating to LT C1 (Hlubek 2010, 368-369). It can serve as a proof of certain activities and possibly even the existence of a communication via Drahany hills even before the existence of the oppidum.

Looking closely at possible communications, we can see that many of them connected Moravia with eastern and central Bohemia. A key communication route passed Moravian Gate that must have been used by the traders transporting, among other things, the highly sought after amber from the Baltic. Amber was processed at Staré Hradisko workshops to make final products and then it was distributed further to the south (Čižmářová 1996). Equally important in the Moravian Gate area were deposits of polymetallic and iron ores that could have been used in the territory of the Púchov culture (Fig. 22) or distributed to the south. Unfortu- nately, no evidence is available thus far for the exploitation of mineral resources in this area.

\subsection{Possible historical circumstances behind the formation of the settlement structure}

Sometime during LT C2 we notice that the settlement pattern in central Moravia started to change. The so far flourishing agglomeration at Němčice ceased to exist and only a small settlement is recorded in its place. The central place in the late La Tène period moved to the oppidum of Staré Hradisko. During the LT D1 a significant reduction in settlement density began in the previously densely occupied lowlands of Haná. Similar trend is recorded also at the oppidum, though the specialised production and long-distance contacts continued to its very end in LT D1b (Danielisová 2020, 134-138). However, even during LT D1 new settlements were still being founded, but in this case in the elevated terrains of the Drahany hills and closer to the oppidum (Fig. 18, 19). We may discuss the possibility that the unstability of the local conditions began already with the change of the location of the central place. Indeed, following 


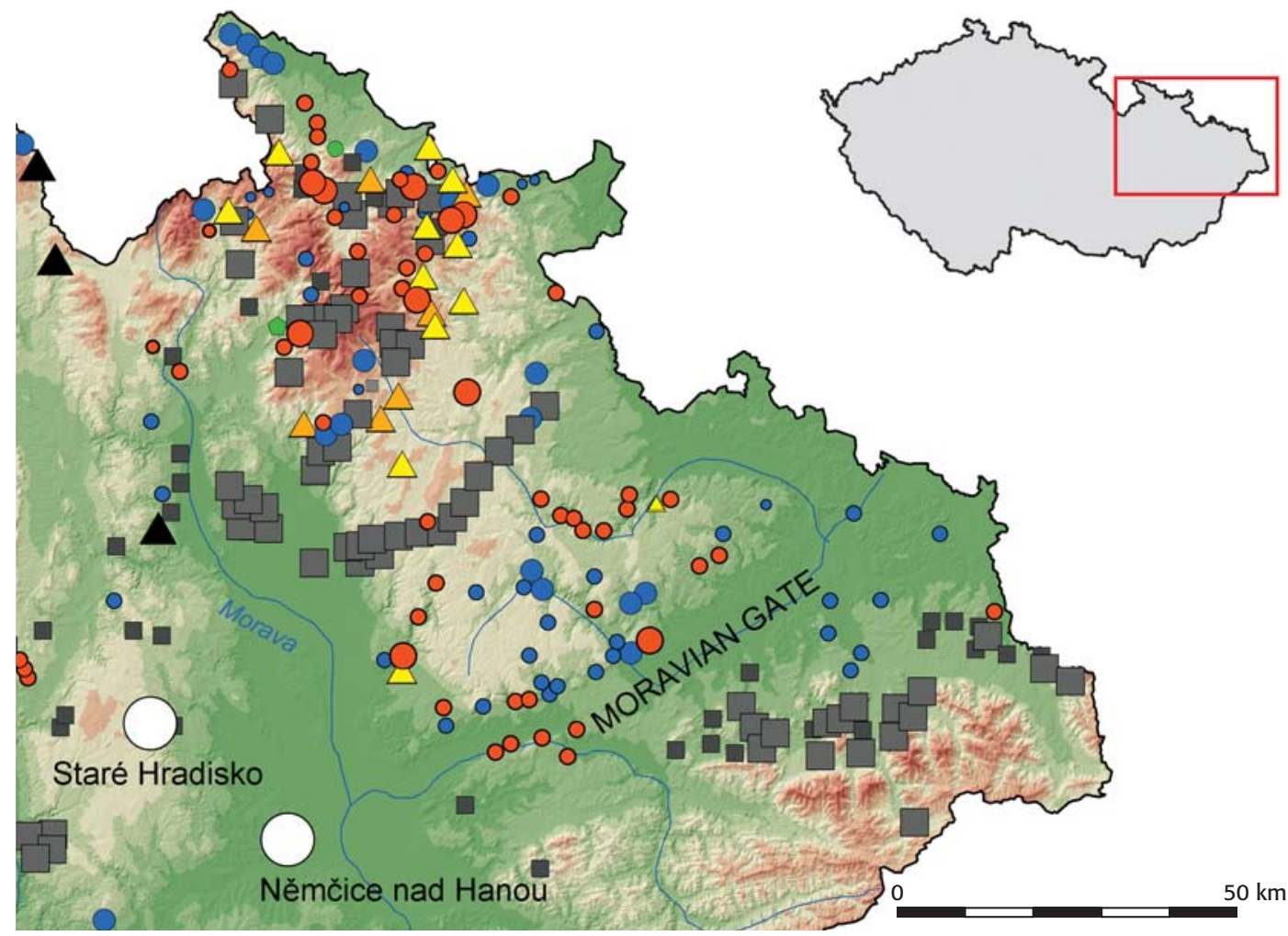

Fig. 22. Mineral resources in the northeastern Moravia and the area of the Moravian Gate: red - copper ores; blue - silver and lead ores; green - cassiterite and tin ores; yellow/orange - gold sources; grey - iron ores; black graphite (source: Czech Geological Survey, author A. Danielisová). - Obr. 22. Nerostné suroviny na severovýchodní Moravě a $v$ oblasti Moravské brány: červeně měděné rudy; modře střibrné a olověné rudy; zeleně - kasiterit a cínové rudy; žlutě/oranžově - zlato; šedě - železné rudy; černè - grafit (zdroj: Česká geologická služba, autor A. Danielisová).

a clearly prosperous settlement network of the LT C2, there is an evidence of a decline, although not necessarily yet a decline of the long-distance contacts or of the prosperity of the elites.

With the occurrence of ceramic types that were so far typical for the Bohemian territory (Jansová 1964; Čižmár̆ 2003), we might expect stronger ties of Staré Hradisko to the west than in the previous phase. The founding of the oppidum was accompanied by new types of material culture, the metal objects, the ceramics, but namely the introduction of a new coin system identical to that of the oppida on the Vltava River in Bohemia, though the coins produced at Němčice appeared at Staré Hradisko in more than negligible amounts (Militký 2018; Hiriart et al. 2020). The discontinuity of socio-economic and possibly also political systems is further confirmed by a new orientation of Mediterranean trade when, compared to LT C2, the new types of imports appeared, namely the bronze vessels. While in the past production focused on locally exploited materials and imported bronze was not recycled, late La Tène bronze metallurgy focused on other sources probably influenced by the long-distance contacts. The abundant sources of iron ore in the Drahany hills as well as along the Moravian Gate could have played a role in the foundation of the oppidum. Iron processing during the late La Tène period played a more important role than it did earlier, as we can tell from the ratio of bronze to iron objects - most notably the frequency of personal objects - that has changed significantly in the late La Tène period (Danielisová 2020, 134-135), as well as frequent hoards of iron tools and other objects in the area of the Púchov culture (Čižmář 2012b; Pieta 2008; Danielisová 2015).

Even during the existence of the oppidum the agglomerations in the lowland along the Valová River
(Klenovice, Polkovice, Hrubčice) continued to be in use (see Fig. 18). New settlements in the lowlands, however, appeared only rarely. As we can see already on the map published by J. Meduna (1980a), the density of settlements in the lowlands to the east of the Morava River towards the southwestern edge of the Moravian Gate is sparse, mostly dating to middle La Tène period (i.e. LT B2-C2; Meduna 1980a, 38, Karte 2). Recent prospections have still not confirmed late La Tène settlements (LT D1) in this area except for the fortified hilltop sites at the southern end of the Moravian Gate (e.g. Loučka 'Obírka', Chvalčov 'Hostýn') whose purpose was probably to control the long-distance route along the Morava River (Čižmář - Salaš 2009, 72).

Several researchers dealt with the issue of the end of the La Tène period in Moravia (e.g. Meduna 1968; 1980a, 164-168; Tejral 1968; Čižmář 1996; Danielisová-Štekerová 2015; Danielisová 2020). In particular, J. Meduna has noted the particularly complex development and the fact that Moravia was probably not 'ethnically uniform' during the late La Tène period. He was the first to point out the presence of the 'Germanic element'. The finds suggested relations with both western as well as eastern Germanic regions. The presence of material of a Germanic origin, according to Meduna, dates to LT D1 and it is mostly associated with Staré Hradisko. While most of the late La Tène settlements and oppida were probably abandoned without suggesting a military conflict, there may be several reasons why the lowlands were gradually vacated during the late La Tène period.

First of all, the presence of 'foreigners', i.e. Germanic tribes which passed through the region towards the end of the second century $\mathrm{BC}$, at the latest, is thought to be linked to the demise of Němčice. Another key factor (al- 
beit unrelated to our territory, but it did influence the situation along the Amber Road) was the massive depopulation of the original territories of the Przeworsk culture, probably due to attested large migration to the west (Dabrowska 1988, 62; Godtowski 1978, 118-122; 1985) during the A2-A2/3 phase according to Przeworsk chronology (LT Dla/b according to La Tène chronology). This process may have affected movement along the long-distance routes during this period. Similarly, smaller or larger fractions of this migrations could have been coming to the south through the Moravian Gate and they could affect the settlement pattern in the region (sites: Bořitov, Brodek u Prostějova, Břest, Dolany, Dubany, Držovice, Količín, Olomouc-Neředín, Pravčice, Rymice, Vyškov, cf. Meduna 1968, 56-58; Dabrowska 1988, 113; Kalábek 1999; 2006; Droberjar 2014; 2019, 256-257; Čižmář 2018, 145). Furthermore, during LT D1 the area of the Púchov culture shrinks substantially and further remains only in the mountainous parts of northern and northwestern Slovakia (Čižmár̆ 1993; Pieta 2008; 2019). The late La Tène population at the oppidum and also in the countryside maintained contacts with the first Germanic people, as confirmed by the finds from Staré Hradisko including mostly the parts of the Germanic costume and the ceramics (Meduna 1968; Čižmár̆ 1996, 368).

Cultural and political changes to the north of our territory were probably the reason for the spread of the La Tène sites in the northern direction, along the still functioning Amber Road. The trade contacts have remained, even though they may have been organised differently, maybe by different elites or mediators (cf. Karwowski 2015, 218, 220).

The presence of La Tène settlements in Poland was probably a result of greater changes connected by the migrations of the Cimbri and Teutoni on a verge between the middle and late La Tène period (Dulęba 2009, 27-29), and later by the movement of the Przework culture (Dabrowska 1988, 62; Godtowski 1978, 118-122; 1985). The La Tène occupation of Poland constituted several individual enclaves symbolising probably different La Tène groups in the present-day Mazovia, Lesser Poland and along the Vistula River. The most significant was the Tyniec group in the Cracow area (Poleska 2006). A major upsweep in the development of this territory is observed during the LT Dlb (Dulęba-Wysocki 2017, 57-58). The Tyniec group served as a connection of the territories along this branch of the Amber Road north of the Moravian gate with the Middle Danube area and the Carpathian basin. This route seems to be operational even after the demise of the oppida in the area to the south, as numerous imports of the Roman origin testify (Dulęba - Wysocki 2017, 62). Common cultural traits with late La Tène territories in Bohemia and Moravia are evidenced by late La Tène brooches (late Nauheim, Cenisola, Beltz J, Almgren 65, and the spoon-shaped brooch; cf. Karwowski 2015; Maciatowicz 2015, 287; Dulęba - Wysocki 2017, 59), the painted ceramic ware (Bryska-Fudali - Przybyla - Rudnicki 2009; Poleska 2006), and especially by the local production of gold coins (the typological derivatives of the Boian mints; Andrałojć - Andrałojć 2012; Dymowski - Rudnicki 2012; Rudnicki et al. 2009; Rudnicki 2010; 2012a; $2012 b$ ) which lasted even sometime after the end of their production at the Czech oppida and is expected to be in operation until the R Bla phase (Rudnicki $2012 b$, 41-42). All these phenomena show an advanced level of the socio-economic and political networks that were operational even after the demise of the networks represented by the oppida in the regions to the south (with the exception of the oppidum in Bratislava).

Late La Tène settlements in the lowlands confirm the presence of the population till the end of the La Tène period and until the demise of Staré Hradisko. The first massive wave of Germanic migrants which is associated with the Großromstedt culture affected only Bohemia, while it is associated with only a handful of sites near Lysická sníženina and Malá Haná Chornice, Sudice and Skalice nad Svitavou (Droberjar 2014, 257). Therefore, Moravian territory at that time was situated between the still functioning network of La Tène settlements in the southwestern Slovakia, possibly organised by the Bratislava oppidum (Čambal 2019; Čambal et al. 2015; Militký 2015; Vrtel 2012), which provided rich material evidence from the LT D2 phase, and the nearly total Germanic occupation of Bohemia. It is possible, that the central Moravian region served as a buffer zone of sorts, as a no-man'sland between the La Tène world and the new 'Germanic world'. Lowlands along the Morava River may have been such land. The total absence of settlements during the second half of the first century BC leads to the thought whether the area of central and southern Moravia belonged to the so-called 'Boian desert' which was thought to have existed in the southwestern Slovakia after the expansion of the Dacians. The corridor of Morava River was again settled no earlier than in the first century AD (Danielisová 2015, 186).

\section{Morava River}

As mentioned above, we have the evidence of an intensive occupation along the western bank of the river during the middle La Tène period. During this period, the Morava River was part of a major long-distance axis connecting northern parts of Moravia with the south. Evidence of the use of the river transport of goods during the middle La Tène period includes a unique wooden monoxyle from Mohelnice. According to dendrochronological analysis, the boat dates to 281 BC (Peška 2020; Rogers 2011, 186). During the late La Tène period, activities along the Morava River were surprisingly rare. Due to nearly total absence of late La Tène settlements at the mouth of the Moravian Gate we can conclude that the river was no longer under the control of the local communities and it was not used as much as it was before.

\section{Conclusions}

Thanks to the detailed chronological assessment of settlements in the territory of central Moravia we managed to untangle the changes in the settlement pattern and communication networks after the foundation of the Staré Hradisko oppidum. A similarly thorough approach has never been applied to the La Tène sites in both Bohemia and Moravia. Based on the data analysis several major conclusions could have been drawn: 
1) Middle La Tène settlements (LT B2-C2, types of sites: A2, B2, C) can be characterised by the location in the fertile lowlands of Haná at elevations around 200$250 \mathrm{~m}$, with their highest concentration forming a relatively regular network within the $20 \mathrm{~km}$ zone around the central agglomeration in Němčice. On the foothills of the Drahany hills, the density of settlements is sparser. On the other hand, during the late La Tène period apparent changes are visible in terms of the spatial structure of settlements following the foundation of Staré Hradisko. The number of sites is much lower (up to $-50 \%$ ) and these settlements were placed at different locations than their middle La Tène predecesors (types of sites A1). We can observe a significant depopulation of the region, especially in its northern part. The trend of moving nearly all settlement activities to higher altitudes is possibly related to the existence of an oppidum located also in the hilly area. The traditional attachment of settlements to black soils was abandoned as sites moved to higher altitudes where the soil is only of mediocre quality (kambisols and light brown soils). A key finding is the continuity of occupation along the Valová River where settlements were formed with respect to natural communication network not affected by the sphere of influence by either of the central places. The area adjacent to the Morava River became deserted with only fortified sites along the Amber Route remaining in operation in the late La Tène period.

2) The relocation of settlements to the more elevated parts of Drahany hills coincides with the more frequent La Tène activities at unfortified hilltop sites in this area. These activities seem to be mostly short-term; a permanent settlement was confirmed only in one case (Stínava 'Ježův hrad').

The purpose of these sites, beside refugial, was probably to control movement on the communications.

3) An important finding was an identification of the production settlements classified as 'settlement agglomerations'. They were situated at the communication corridor along the Valová River and they remained functioning continuously since LT A. Interesting is their spatial form of some loose agglomeration of the households dispersed over the large area along the local watercourse. At all of them, the evidence was found of specialised production since LT C2. Judging by a large number of coins we can assume that these were also produced here (also confirmed by the discovery of a coin mould at Klenovice). A similar theory applies to the Bohemian site of Žehuň where new types of coins were discovered which can be linked to their production on-site (Danielisová et al. 2018). It should also be pointed out that all these sites gave us evidence of the occupation during the Roman period when they also seemed to have served as minor local centres.

4) Material analysis has confirmed that the proportion of pottery with graphite content diminished during the late La Tène period. The reduction of distribution of graphite ware was probably related to the limited use of the communication along the Morava River in the direction towards the present-day Mohelnice where graphite deposits were located. Only at settlements directly at this communication, the proportion of graphite pottery remained high (ca. 30\%). It allows us to follow the route used to transport the raw material to Staré Hradisko where graphite content in pottery remained also high.
5) Discontinuity is also observed in the bronze production at Němčice and Staré Hradisko. While the older production relied on various sources of the raw material and did not recycle the Mediterranean imports coming there in the form of bronze coins, the production of Staré Hradisko was homogeneous and possibly used the only limited number of sources. The categories of the Roman import have changed as well; the bronze coins from the earlier period were replaced by heavily leaded bronze vessels from northern Italy that contained lead coming from southwestern Spain. This affected largely the geochemical pattern of the local copper alloys, that possibly partly used the imported metals as the source material for recycling.

6) Spatial classification of settlements during the late La Tène period confirms the presence of local communication network connected to major routes (e.g. the Amber Road). The most prominent is perhaps the one along the Valová River which was used extensively at least since LT C1 (half of the third century BC). Adjacent to this route was a communication route across the Drahany hills, along Romže and Nectava, thereby connecting the region with the northern part of Boskovická brázda and further away with eastern Bohemia (Fig. 21). Based on more recent finds, existence was confirmed of a route along Staré Hradisko to Lysická sníženina and a settlement of Bořitov whose material assemblage is similar to that of Staré Hradisko. Interestingly, cessation of activities was observed along the major communication route along the Morava River since the onset of the late La Tène period. This may be associated with the increased presence of the Germanic sites in the region.

7) Considering the fact that during LT C1-C2 there were twice as many settlements than during LT D1, we can assume a decrease in the number of settlements and the resulting drop in the population density. The significant change in the region at the beginning of LT D 1 may at least theoretically be linked to the historical events either north of the territory in question (in Poland the migration of the Przeworsk culture is dated to the A2 phase, or end of LT C2/D1) or maybe even within it (the problematic issue of the migration of Cimbri and Teutoni in the $2^{\text {nd }} / 1^{\text {st }}$ century BC). All these events, though only loosely evidenced in contemporary history or, indeed also, the archaeological record, possibly meant some influx of the Germanic people during LT D1 (references above). The demise of Staré Hradisko is thought to have occurred at the end of LT D1 (ca. middle of the first century BC). Previous transfer of settlements to higher altitudes resulted in the overall change of the settlement pattern which probably disappeared along with the end of occupation of the oppidum.

\section{Acknowledgements}

This study was funded by project Nr. 18-20096S 'Mobility of materials and life cycles of artefacts: archaeometry of metals and glass of the La Tène and Early Roman period' of the Czech Science Foundation (GA ČR).

English by Petr Bokůvka 


\section{Souhrn}

Hmotná kultura střední a mladší doby laténské na střední Moravě (obr. 1) byla silně ovlivněna přítomností centrální aglomerace v Němčicích nad Hanou a jejím působením na okolní sídliště. Na základě odtud pocházejících nálezů je možné tuto lokalitu datovat do rozmezí stupňů LT B2 - LT C2 (3.-2. století př. Kr.), s největším rozmachem řemeslné výroby a obchodní činnosti ve stupni LT C1-C2 (250-180 př. Kr.; cf. Čižmář - Kolníková 2006, 267). Ojedinělé nálezy získávané mimo jiné $z$ nejnovějších prospekcí ukazují, že je zde nutné počítat také s aktivitami ve stupních LT B1 a LT D1. Sídliště ležící v zázemí Němčic byla podobně jako centrální aglomerace orientována na podunajskou oblast, což dokládá hojný výskyt různých typů artefaktů této provenience. Dálkové kontakty, doložitelné především nálezy mediterránních mincí z prostoru Egypta, Syrakús a Kartága, spojovaly Němčice se severní Itálií a souvisely pravděpodobně s orientací obchodu na nově založené centrum Aquileia v adriatické oblasti (Kysela 2017).

Ke konci stupně LT C2 (cca 150 př. Kr.) vzniká oppidum Staré Hradisko a v souvislosti s ním se na Moravě setkáváme $\mathrm{s}$ vlivy laténské kultury z Čech. Vznikají nová sídliště v doposud neosídlených polohách, v menší míře však pokračuje také osídlení v polohách původních. Specializovaná výroba, stejně jako dálkové kontakty, jsou koncentrovány přímo na oppidu a z jeho zázemí pocházejí pouze sporadické doklady těchto aktivit. Podél komunikací lze lokalizovat výjimečné nálezy jako jsou depoty (např. Ptení, cf. Čižmár̆ 2002b). Osídlení na oppidu vyznívá na konci stupně LT D1 (cca kolem poloviny 1. století př. Kr.) a zdá se, že podobně je tomu také u sídlišt v jeho zázemí. Laténské osídlení mladší stupně LT D1 v regionu střední Moravy doloženo není.

Při datování sídlišt narážíme na problém částečného překrývání časového rozpětí osídlení dvou centrálních lokalit. Je zřejmé, že vrchol rozkvětu centrální aglomerace v Němčicích spadá do stupně LT C2 (dvě generace mezi cca 180-120 př. Kr.), přičemž založení oppida Staré Hradisko můžeme klást již do závěrečné fáze téhož stupně. Kontinuta ve společenských, ekonomických či politických strategiích obou lokalit zatím není dostatečně poznána. U některých sídlištních lokalit datovaných do stupně LT C2 tak vzniká obtížná situace, kdy nelze určit, zda osídlení spadá do sféry vlivu Starého Hradiska nebo Němčic. Jedním $z$ cílů této studie je tedy snaha podchytit chronologické zařazení všech sídlišt a pokusit se je přiřadit k příslušné centrální lokalitě. Na základě tohoto vyhodnocení je pak možné vymezit prostor zázemí obou výše uváděných centrálních lokalit a pokusit se zrekonstruovat vývoj struktury osídlení a z toho plynoucích ekonomických strategií ve sledovaném regionu.

Na základě rešerše dostupného materiálu a z ní vycházejícího chronologického rozdělení sídlištních lokalit se podařilo poodhalit v jejich rozložení, dříve považovaném za rovnoměrné, skryté obchodní stezky a změnu sídelní (i politicko-ekonomické) strategie v regionu po vzniku oppida Staré Hradisko. Podobný postup nebyl pro dobu laténskou dosud nikde aplikován. Kromě rady dílčích zjištění byly na základě zpracování dat učiněny následující závěry:

Pro osídlení ve střední době laténské (LT B2-C2, sídliště skupiny $\mathrm{A} 2, \mathrm{~B} 1, \mathrm{~B} 2, \mathrm{C})$ je příznačné zakládání sídlištních lokalit v úrodné oblasti nížinné Hané v nadmořských výškách 200-250 $\mathrm{m}$, přičemž nejhustší osídlení tvoří celkem pravidelnou sít ve vzdálenosti do $20 \mathrm{~km}$ od centrální aglomerace v Němčicích. Ve vyšším pásmu úpatí masivu Drahanské vrchoviny je možné sledovat osídlení jen velmi řídké (obr. 5). Naopak v období pozdní doby laténské (LT C2-D1, sídliště skupiny A1) je jasně patrná změna prostorové organizace sídlišt po založení oppida Staré Hradisko. Z regionu známe výrazně (až o polovinu) nižší počet sídlište, která byla navíc $\mathrm{v}$ řadě případů zakládána na zcela nových místech. Je zde vidět téměř úplné vymizení osídlení v regionu, a to především v jeho severní části. Tendence přesunu téměř veškerých sídelních aktivit do vyšších nadmořských výšek souvisí nepochybně s existencí oppida položeného ve východní části Drahanské vrchoviny. Osídlení se vyvázalo z tradiční vazby na černozemě v nížinách a přesunulo se do vyšších poloh, kde jsou zastoupeny půdy nižší bonity, především kambizemě a hnědozemě. Velmi důležitým poznatkem je ovšem evidentní zachování/pokračování osídlení v nížině podél řeky Valové. Region podél řeky Moravy však je až na několik výjimek prakticky neosídlen.

S přesunem osídlení do kopcovitější oblasti Drahanské vrchoviny registrujeme také častější pozdně laténské aktivity na neopevněných výšinných polohách v tomto prostoru, přičemž trvalejší osídlení bylo prokázáno zatím pouze v jediném případě. Účel těchto poloh lze spatřovat $\mathrm{v}$ kontrole a snad také ochraně dálkových obchodních cest.

Důležité je rozpoznání výrobních center označovaných jako „aglomerace“. Ty jsou striktně situovány v rámci důležitého obchodního koridoru podél řeky Valové a osídlení na nich je nepřetržité po celé období laténu již od stupně LT A. Na všech se podařilo doložit specializovanou výrobu v období stupně LT C2 a početné nálezy mincí dovolují uvažovat o jejich zdejší produkci v tomto období, což podporuje i nález mincovní destičky z Klenovic. Podobné je to např. v př́ipadě české lokality Žehuň, kde se objevují nové typy mincí, které snad lze spojit s mincovní produkcí na této lokalitě (Danielisová et al. 2018). Je třeba také připomenout, že na všech těchto důležitých lokalitách bylo zjištěno osídlení $\mathrm{z}$ doby římské, a podobně jako $\mathrm{v}$ době laténské, i v tomto období šlo o menší centrální místa využívaná v dlouhodobém časovém horizontu.

Porovnáním zastoupení keramických hmot ve vybraných souborech bylo potvrzeno, že na sídlištích v pozdní době laténské dochází $\mathrm{k}$ výraznému úbytku podílu keramiky s př́měsí tuhy. Omezení distribuce grafitu patrně souvisí s výrazně nižším využíváním obchodní trasy podél řeky Moravy ve směru na Mohelnici, v jejímž okolí se nacházejí povrchová ložiska této suroviny. Faktem ovšem zůstává, že na všech pozdně laténských sídlištích blízkých této trase se setkáváme s vysokým zastoupením grafitové keramiky (okolo $30 \%$ ). Je tak možné zmapovat koridor, kudy byla grafitová surovina distribuována na oppidum Staré Hradisko, kde je podíl grafitové složky rovněž výrazný, snad z důvodu preference zásobování centrální lokality oproti ostatním sídlištím v jejím zázemí.

Prostorové vymezení sídlištních poloh v pozdní době laténské ukazuje na přítomnost několika lokálních obchodních tras či komunikačních koridorů. Prvním a zcela zásadním je již výše zmíněný koridor podél řeky Valové, intenzivně využívaný nejpozději od stupně LT C (polovina 3. století př. Kr.), v němž se nacházejí prakticky všechna větší sídliště označovaná jako „aglomerace“. Na tuto komunikaci bezprostředně navazovala přirozená obchodní trasa přes masiv Drahanské vrchoviny podél toků Romže a Nectavy, spojující sledovaný region se severní částí Boskovické brázdy a pokračující dále do východních Čech (obr. 21). Dle novějších nálezů se dále potvrdila také existence stezky vedoucí podél oppida Staré Hradisko na západ př́imo přes masiv Drahanské vrchoviny až do oblasti Lysické sníženiny, ve které leží oppidu materiálově blízké sídliště v Bořitově. $\mathrm{V}$ pozdní době laténské se ovšem projevuje také útlum, nebo dokonce zánik obchodní trasy vedoucí po řece Moravě. Ještě ve stupni LT C2 podél řeky registrujeme větší množství sídlišt a nálezů, v pozdní době laténské zde však osídlení zaniká (obr. 5), což může souviset právě s nevyužíváním této komunikace, nebo s postupným objevováním se lokalit s nálezy przeworské kultury.

Vezmeme-li v potaz téměř dvojnásobný počet sídlištních lokalit v období stupňủ LT C1-C2 oproti stupni LT D1, lze i bez dalších analýz zabývajících se hustotou osídlení zřetelně sledovat výrazný úbytek sídlištních poloh v regionu a s ním také související nižší hustotu obyvatel. Jejich částečný odchod na počátku stupně LT D1 může teoreticky souviset s historickými událostmi: migrace przeworské kultury na území dnešního Polska a postupné pronikání dalších germánských kmenů na naše území. Na konci stupně LT D1 se předpokládá zánik oppida Staré Hradisko. Předchozí přesun osídlení do vyšších poloh tak znamenal počátek procesu změny struktury osídlení regionu, který po zániku oppida, af již byly důvody jakékoliv, jen umocnil ráz neosídlené krajiny ve druhé polovině 1 . století př. Kr. 


\begin{tabular}{|c|c|c|c|c|c|c|c|}
\hline ID & Cadastre & Location & Y-JTSK & X-JTSK & Dating & \begin{tabular}{|c|} 
Code of \\
the site \\
for the \\
analysis \\
\end{tabular} & Type of the evidence \\
\hline 1 & Bedihošt' & to the east of the station, 'U cukrovaru' & $-1137751,63$ & $-554751,25$ & LT A, LT B-C1, LT C2-D1 & A2 & SIDL (settlement) \\
\hline 2 & Bílovice & 'Pod Hájem' & $-1128000,81$ & $-564841,34$ & LT C2-D1 & $\mathrm{A} 1$ & SIDL (settlement) \\
\hline 3 & Biskupice & 'Ostrov' & $-1135072,17$ & $-549181,29$ & LT A, LT B-C1, LT C-D, LT C2-D1 & $\mathrm{A} 2$ & SIDL (settlement) \\
\hline 4 & Biskupice & 'Dvorské' & $-1134662,62$ & $-549798,25$ & LT A, LT B-C & $\mathrm{C}$ & SIDL (settlement) \\
\hline 5 & Blatec & 'Kocanda' & $-1128580,06$ & $-547733,2$ & LT B-C1 & $\mathrm{C}$ & SIDL (settlement) \\
\hline 6 & Brodek u Prostějova & 'Bažantice' & $-1144672,53$ & $-561701,33$ & $\begin{array}{l}\text { LT A, LT B-C1, late LT (LT C2) } \\
\text { without the evidence LT D1 }\end{array}$ & B2 & SIDL (settlement) \\
\hline 7 & Čehovice & 'Loučky před drahou' & $-1138211,3$ & $-554824,22$ & $\begin{array}{l}\text { late LT C-D without the } \\
\text { evidence of LT D1 }\end{array}$ & B1 & SIDL (settlement) \\
\hline 8 & Čehovice & 'Louky', 'Jeleta' & $-1139566,39$ & $-553186,52$ & LT B-C1, LT C2-D1 & $\mathrm{A} 2$ & SIDL (settlement) \\
\hline 9 & Čechy pod Kosiřem & 'Pod Brusem' & -1125336 & $-565359,03$ & LT C-D & $\mathrm{B} 1$ & SIDL (settlement) \\
\hline 10 & Čechy pod Kosiřem & 'Vařekova zmola' & $-1126277,09$ & $-561339,04$ & LTC & $\mathrm{C}$ & OJ (stray find) \\
\hline 11 & Čechy pod Kosiřem & 'Ve Žlíbkách' & $-1125230,1$ & $-565244,78$ & LT C-D, LT C2-D1 & $\mathrm{A} 1$ & SIDL (settlement) \\
\hline 12 & Čechy pod Kosiřem & 'U vazu' & $-1124019,76$ & $-565513,3$ & LT B-C1 & $\mathrm{C}$ & SIDL (settlement) \\
\hline 13 & Čelčice & 'Louky', 'Člupy' & $-1139966,96$ & $-552994,61$ & LT B-C & $\mathrm{C}$ & SIDL (settlement) \\
\hline 14 & Dětkovice & 'Skaličníky' & $-1139588,84$ & $-561934,64$ & LT in general (perhaps LT A) & $\mathrm{D}$ & OJ (stray find) \\
\hline 15 & Dětkovice & 'Sibiri' & $-1139861,36$ & $-561725,62$ & LT D1 & $\mathrm{A} 1$ & SIDL (settlement) \\
\hline 16 & Doloplazy & 'U hrišště' & $-1147430,87$ & $-556656,11$ & LT A, LT D1 & $\mathrm{A} 1$ & SIDL (settlement) \\
\hline 17 & Držovice & 'Díly odvrahovični' & $-1132505,14$ & $-555872,23$ & LT B-C1, LT C-D, LT C2-D1 & $\mathrm{A} 2$ & SIDL (settlement) \\
\hline 18 & Držovice & 'Pastviska' & $-1131703,45$ & $-557107,84$ & LT A, LT B-C1, LT C2-D1 & $\mathrm{A} 2$ & SIDL (settlement) \\
\hline 19 & Držovice & 'Horky' & $-1132270,98$ & $-557613,19$ & LT A, LT B-C & $\mathrm{C}$ & SIDL (settlement) \\
\hline 20 & Dřevnovice & built-up area & $-1150048,51$ & $-557616,34$ & LT B-C1 & $\mathrm{C}$ & STOPA (trace) \\
\hline 21 & Dubany & 'Nad lukami' & $-1129128,4$ & $-552825,9609$ & LT C-D, LT C2-D1 & $\mathrm{A} 1$ & SIDL (settlement) \\
\hline 22 & Hněvotín & 'Dolní slavonínská' & $-1123720,26$ & $-551790,43$ & LT B-C & $\mathrm{C}$ & SIDL (settlement) \\
\hline 23 & Hněvotín & 'Trat legii' & $-1125579,11$ & $-553639,31$ & LT B-C & $\mathrm{C}$ & SIDL (settlement) \\
\hline 24 & Hněvotín & 'U zahrádek', 'Za Válkovem' & $-1123501,61$ & $-552058,69$ & LT B-C, C2-D1 & $\mathrm{A} 2$ & SIDL (settlement) \\
\hline 25 & Hradčany & 'Zadka' & $-1144482,06$ & $-558091,73$ & LT in general & $\mathrm{D}$ & SIDL (settlement) \\
\hline 26 & Hrdibořice & 'Spálenky' & $-1133297,9$ & $-550832,44$ & $\begin{array}{l}\text { LT A, LT B-C1, late LT (LT C2) } \\
\text { without the evidence of LT D1 }\end{array}$ & B2 & SIDL (settlement) \\
\hline 27 & Hrubčice & 'Ostrov' & $-1138805,13$ & $-551952,13$ & LT A, LT B-C1, LT C2-D1 & A2 & AGLOM (agglomeration) \\
\hline 28 & Hrubčice & 'Podluči' & $-1138214,05$ & $-552422,02$ & LT in general & $\mathrm{D}$ & SIDL (settlement) \\
\hline 29 & Cholina & to the east of the village & $-1112873,48$ & $-560282,03$ & LT C2-D1 & A1 & SIDL (settlement) \\
\hline 30 & Ivaň & 'Zadní díly' & $-1139098,84$ & $-550655,19$ & $\begin{array}{l}\text { LT A, LT B-C1, LT B-C, LT C2-D, } \\
\text { late LT without the evidence } \\
\text { of LT D1 }\end{array}$ & B2 & SIDL (settlement) \\
\hline 31 & Ivaň & 'Bažantice' & $-1139508,95$ & $-550472,63$ & LT in general & $\mathrm{D}$ & STOPA (trace) \\
\hline 32 & Ivaň & 'Nivky' & $-1141296,21$ & $-549218,5$ & LT B-C1, LT B-C & C & SIDL (settlement) \\
\hline 33 & Ivaň & 'Opleta' & $-1140380,37$ & $-550150,71$ & LT B-C & C & STOPA (trace) \\
\hline 34 & Ivaň & boundary of the Ivañ and Oplocany cadastres & $-1141869,72$ & $-549099,17$ & LT B-C1 & C & SIDL (settlement) \\
\hline 35 & Kelčice & 'Přední nivy' & $-1141634,98$ & $-558776,95$ & LT A, LT D1 & $\mathrm{A} 1$ & SIDL (settlement) \\
\hline 36 & Kelčice & 'Zadní míry' & $-1140802,22$ & $-558212,16$ & LT in general & $\mathrm{D}$ & STOPA (trace) \\
\hline 37 & Klenovice na Hané & 'Noviny', 'Staré Podíly', 'Louky za dvorem' & -1140813 & $-550930,14$ & LT A, LT B-C1, LT C2-D1 & $\mathrm{A} 2$ & AGLOM (agglomeration) \\
\hline 38 & Klopotovice & 'Vršiny' & $-1137596,08$ & $-548466,14$ & LT B-C in general & $\mathrm{C}$ & SIDL (settlement) \\
\hline 39 & Klopotovice & right riverside of Blata & $-1138429,78$ & $-547900,47$ & LT C2, LT C2-D1 & $\mathrm{A} 2$ & SIDL (settlement) \\
\hline 40 & Kojetín & 'Babiny' & $-1150039,37$ & $-548572,36$ & $\begin{array}{l}\text { LT B-C1, late LT } \\
\text { (with certainty LT C2) } \\
\text { without the evidence of LTD1 } \\
\end{array}$ & B2 & SIDL (settlement) \\
\hline 41 & Kojetín & 'Hrádek' & -1150087 & $-545196,28$ & LT B-C1, LT B-C & $\mathrm{C}$ & SIDL (settlement) \\
\hline 42 & Kojetín & 'Niva pod oborou' & $-1147572,42$ & $-546321,67$ & LT C2-D1 & $\mathrm{A} 1$ & STOPA (trace) \\
\hline 43 & Kralice na Hané & 'Mokřiny' & $-1136342,17$ & $-554576,14$ & $\begin{array}{l}\text { LT C, late LT (LTC2) } \\
\text { without the evidence of LT D1 }\end{array}$ & B2 & SIDL (settlement) \\
\hline 44 & Kralice na Hané & 'Kralický háj' & $-1134631,64$ & $-555996,95$ & LT B-C1, LT C2 & $\mathrm{C}$ & SIDL (settlement) \\
\hline 45 & Krumsin & 'Želi' & $-1136187,53$ & $-565744,75$ & LT C2-D1 & $\mathrm{A} 1$ & SIDL (settlement) \\
\hline 46 & Laškov & 'Na kuse' & $-1120793,27$ & $-564399,33$ & $\begin{array}{l}\text { LT C-D without the evidence } \\
\text { of LT D1 }\end{array}$ & B1 & SIDL (settlement) \\
\hline 47 & Lešany & 'Nad Dluhošticemi' & $-1129557,01$ & $-565293,36$ & LT C-D, LT C2-D1 & A1 & SIDL (settlement) \\
\hline 48 & Lešany & 'Na lukách', 'Luka pod Sarasy' & $-1130820,4$ & $-563187,27$ & LT B-C1 & $\mathrm{C}$ & SIDL (settlement) \\
\hline 49 & Lešany & centre of the village, village square & $-1130223,68$ & $-564640,76$ & LT A, LT B-C & $\mathrm{C}$ & SIDL (settlement) \\
\hline 50 & Lešany & 'Za Hemerkovým' & $-1130373,25$ & $-564809,17$ & $\begin{array}{l}\text { LT C-D without } \\
\text { the evidence of LT D1 }\end{array}$ & B1 & SIDL (settlement) \\
\hline 51 & Litovel & 'U hráze' & $-1109563,03$ & $-559440,73$ & LT B-C & $\mathrm{C}$ & SIDL (settlement) \\
\hline 52 & Litovel-Nasobůrky & 'Chmelník' & $-1109905,91$ & $-559454,88$ & LT B-C & $C$ & SIDL (settlement) \\
\hline
\end{tabular}




\begin{tabular}{|c|c|c|c|c|c|c|c|}
\hline ID & Cadastre & Location & Y-JTSK & X-JTSK & Dating & \begin{tabular}{|c|} 
Code of \\
the site \\
for the \\
analysis
\end{tabular} & Type of the evidence \\
\hline 53 & Litovel-Nasobůrky & 'Kotrflek' & $-1109331,23$ & $-560426,73$ & $\begin{array}{l}\text { LT C-D without the evidence } \\
\text { of LT D1 }\end{array}$ & B1 & SIDL (settlement) \\
\hline 54 & Lobodice & 'Niva u Cvrčova' & $-1142764,96$ & $-546482,13$ & LT A, LT C2-D1 & $\mathrm{A} 1$ & STOPA (trace) \\
\hline 55 & Loučany & on the left of the road to Senice na Hané & $-1119044,45$ & $-559424,06$ & LT B2 & $\mathrm{C}$ & SIDL (settlement) \\
\hline 56 & Ludéřov & 'Švédské šance' & $-1121085,36$ & $-562312,84$ & LT C2-D1 & $\mathrm{A} 1$ & VIER \\
\hline 57 & Lutotín & 'Zlámané' & $-1128175,48$ & $-564696,85$ & LT B-C1, LT C2-D1 & A2 & SIDL (settlement) \\
\hline 58 & Lutotín & built-up area & $-1128157,99$ & $-563746,3$ & LT C2-D1 (rotary quern) & $\mathrm{A} 1$ & SIDL (settlement) \\
\hline 59 & Malé Hradisko & 'V zadcích' & $-1129979,66$ & $-576833,18$ & LT B2-C1 & C & OJ (stray find) \\
\hline 60 & Malé Hradisko & 'Za silnici' & $-1130808,4$ & $-576443,82$ & LT C2-D1 & Al & OJ (stray find) \\
\hline 61 & Měrovice nad Hanou & 'Svárovy' & $-1149701,77$ & $-579216,36$ & LT B-C1, LT C2 & $\mathrm{C}$ & SIDL (settlement) \\
\hline 62 & Měrovice nad Hanou & 'Pod Gervizem' & -1149325 & $-550666,54$ & LTC2 & $\mathrm{B} 1$ & OJ (stray find) \\
\hline 63 & Mezice & 'Jamniska', 'Ve stěžkách' & $-1113555,33$ & $-556398,98$ & $\begin{array}{l}\text { LT B-C, LT C-D without } \\
\text { the evidence of LT D1 }\end{array}$ & B1 & SIDL (settlement) \\
\hline 64 & Mladeč & 'Třesín' & $-1107002,98$ & $-563993,83$ & LT B-D & $\mathrm{D}$ & OJ (stray find) \\
\hline 65 & Myslejovice & $\begin{array}{l}\text { 'Úzké, 'Pod Krenovskou cestou', } \\
\text { 'Prostřední hony' }\end{array}$ & $-1140328,77$ & $-565187,71$ & \begin{tabular}{|l|} 
LT B-C, late LT (LT C2) \\
without the evidence of LT D1
\end{tabular} & B2 & SIDL (settlement) \\
\hline 66 & \begin{tabular}{|l|} 
Myslejovice \\
\end{tabular} & 'Na kopci u pijávek' & $-1140804,33$ & $-564881,59$ & LT C-D1 & B1 & OJ (stray find) \\
\hline 67 & Myslejovice & house no. 89 & $-1140608,53$ & $-565442,51$ & LT in general (in literature) & $\mathrm{C}$ & DEPOT (hoard) \\
\hline 68 & Myslejovice & 'dil' from no. 70 & $-1140900,27$ & $-565327,94$ & $L T$ in general & D & STOPA (trace) \\
\hline 69 & Náklo & to the north of the church & $-1113729,95$ & $-554927,9$ & \begin{tabular}{|l|} 
LT B-C1, late LT (LT C-D) \\
without the evidence of LT D1 \\
\end{tabular} & B2 & SIDL (settlement) \\
\hline 70 & Náměšt na Hané & 'Rmíz' & $-1120070,98$ & $-564023,24$ & LT in general & D & STOPA (trace) \\
\hline 71 & Náměšt na Hané & 'Tabule' & $-1118887,4$ & $-564023,24$ & LT C2-D1 & $\mathrm{A} 1$ & OJ (stray find) \\
\hline 72 & Němčice nad Hanou & 'Daňka' & $-1149655,73$ & $-555057,3$ & LT B-C1 & C & STOPA (trace) \\
\hline 73 & Němčice nad Hanou & 'Na Loukách' & $-1149325,8$ & $-552021,59$ & LT C2-D1 & $\mathrm{A} 1$ & OJ (stray find) \\
\hline 74 & Němčice nad Hanou & 'Mlynářova zahrada', 'Nad mlýnem' & $-1148561,15$ & $-553585,27$ & LT B-C & $\mathrm{C}$ & OJ (stray find) \\
\hline 75 & Němčice nad Hanou & 'Palackého náměstí č. p. 17' & $-1148868,07$ & $-553175,17$ & LT B-C1 & $\mathrm{C}$ & STOPA (trace) \\
\hline 76 & Němčice nad Hanou & 'Pastvisko' & $-1149153,43$ & $-554277,73$ & $\begin{array}{l}\text { LT A, LT B1, LT B2, LT C, LT C2, } \\
\text { late LT (LT C-D) without the } \\
\text { evidence of LT D1 }\end{array}$ & B2 & SIDL (settlement) \\
\hline 77 & Ohrozim & 'Hrabovec' & $-1132011,36$ & $-564952,59$ & LT C2-D1 & $\mathrm{A} 1$ & SIDL (settlement) \\
\hline 78 & Ohrozim & 'Močilky' & $-1132302,4$ & $-565034,61$ & LT B-C1, LT C2-D1 & $\mathrm{A} 2$ & SIDL (settlement) \\
\hline 79 & Ohrozim & built-up area, house no. 120 & $-1131745,46$ & $-565103,4$ & LT B-C & $\mathrm{C}$ & SIDL (settlement) \\
\hline 80 & Ohrozim & house no. 41 & $-1131566,86$ & $-564952,59$ & LT A, LT B-C1 & $\mathrm{C}$ & SIDL (settlement) \\
\hline 81 & Ohrozim & to the southwest of the municipality & $-1131997,73$ & $-565336,64$ & $\begin{array}{l}\text { LT A, LT B-C1, LT C-D without } \\
\text { the evidence of LT D1 }\end{array}$ & B2 & SIDL (settlement) \\
\hline 82 & Ohrozim & to the north of the municipality & $-1131099,87$ & $-564661,55$ & LT C2-D1 & $\mathrm{A} 1$ & SIDL (settlement) \\
\hline 83 & Olomouc & $\begin{array}{l}\text { church of 'Neposkvrněné početí P. Marie' } \\
\text { (Immaculate Conception), Slovenská street }\end{array}$ & $-1121172,88$ & $-547182,78$ & LT B-C1 & B2 & SIDL (settlement) \\
\hline 84 & Olomouc & Spojenců avenue - Palackého street & $-1121200,76$ & $-547546,68$ & LT C-D, C2-D1 & B1 & STOPA (trace) \\
\hline 85 & Olomouc & Václavské náměstí č. 5, č. p. 811/4 & $-1121114,67$ & $-546309,65$ & LTC & C & STOPA (trace) \\
\hline 86 & Olomouc-Nemilany & $\begin{array}{l}\text { 'Kapitulni', southwest verge, Bylinková street, } \\
\text { Kožušanská street }\end{array}$ & $-1125884,23$ & $-547751,45$ & LT B-C & C & SIDL (settlement) \\
\hline 87 & Olomouc-Neředín & 'Mýlina', 'Dlouhé dily' & $-1121320,46$ & $-549644,44$ & LT A, LT B-C, LT D & $\mathrm{A} 2$ & SIDL (settlement) \\
\hline 88 & Olomouc-Řepčín & 'Horní nivy' & $-1120163,08$ & $-550229,95$ & LT B-C & $\mathrm{C}$ & SIDL (settlement) \\
\hline 89 & Olomouc-Slavonín & 'Za Křenkovým' & $-1123862,84$ & $-548172,95$ & LT B-C1 & $\mathrm{C}$ & SIDL (settlement) \\
\hline 90 & Olšany & dairy & $-1127348,48$ & $-553806,88$ & LT A, LT B-C1, LT C & $\mathrm{C}$ & SIDL (settlement) \\
\hline 91 & Olšany & 'Lánský křǐž' & $-1127710,96$ & $-554402,19$ & LT C-D & B1 & STOPA (trace) \\
\hline 92 & Olšany & 'Zlatniska' & $-1126681,48$ & $-554397,3$ & $\begin{array}{l}\text { LT A, LT B-Cl, LT B-C, LT C-D } \\
\text { without the evidence } \\
\text { of LT D1 }\end{array}$ & B2 & SIDL (settlement) \\
\hline 93 & Oplocany & 'Švýcarky' & $-1142730,77$ & $-549608,88$ & LT B-C1, LT C2-D1 & $\mathrm{A} 2$ & SIDL (settlement) \\
\hline 94 & Otaslavice & 'Vápeničky' & $-1143590,92$ & $-562564,47$ & $\mathrm{LT}$ in general & $\mathrm{D}$ & STOPA (trace) \\
\hline 95 & Otaslavice & 'Malé zahrádky' & $-1143078,16$ & $-562145,37$ & LT A, LT B-C1 & $\mathrm{C}$ & SIDL (settlement) \\
\hline 96 & Otaslavice & 'Svodnice' & $-1143549,12$ & $-563365,1$ & LT A, LT D1 & $\mathrm{A} 1$ & STOPA (trace) \\
\hline 97 & Otaslavice & 'Obrova noha' & $-1143190,34$ & $-564159,91$ & LT C-D & B1 & OJ (stray find) \\
\hline 98 & Plumlov & vicinity of Hampl villa & $-1133737,21$ & $-564881,3$ & LT C2-D1 & $\mathrm{A} 1$ & SIDL (settlement) \\
\hline 99 & Plumlov & 'Za hřbitovem' & $-1133788,6$ & $-566669,33$ & LT in general & $\mathrm{D}$ & SIDL (settlement) \\
\hline 100 & Polkovice & 'Ostrov' & $-1143008,59$ & $-549262,28$ & LT A, LT B-C1, LT C2-D1 & $\mathrm{A} 2$ & AGLOM (agglomeration) \\
\hline 101 & Polkovice & 'Apatyky', 'Trávníky' & $-1143256,76$ & $-548999,24$ & \begin{tabular}{|l|} 
LT B-C1, LT C, LT C-D (late LT \\
without the evidence of LT D1) \\
\end{tabular} & B2 & SIDL (settlement) \\
\hline 102 & Polkovice & 'Široký' & $-1143862,13$ & $-548016,05$ & LT B-C1 & C & SIDL (settlement) \\
\hline
\end{tabular}




\begin{tabular}{|c|c|c|c|c|c|c|c|}
\hline ID & Cadastre & Location & Y-JTSK & X-JTSK & Dating & $\begin{array}{l}\text { Code of } \\
\text { the site } \\
\text { for the } \\
\text { analysis }\end{array}$ & Type of the evidence \\
\hline 103 & Prostějov & $\begin{array}{l}\text { field by the city slaughterhouse, Dolní street, } \\
\text { Šárka street, house no. } 101\end{array}$ & $-1134663,69$ & $-557377,33$ & LT A, LT B-C1, LT C2-D1 & A2 & SIDL (settlement) \\
\hline 104 & Prostějov & Sadová street, U sv. Anny street & $-1134171,57$ & $-560054,92$ & $\begin{array}{l}\text { LT B-C1, late LT (LT C-D) } \\
\text { without the evidence of LT D1 }\end{array}$ & B2 & SIDL (settlement) \\
\hline 105 & Prostějov & Hradebni street & $-1134060,44$ & $-558599,71$ & LT in general & $\mathrm{D}$ & STOPA (trace) \\
\hline 106 & Prostějov & 'Za Kovárnou' & $-1132206,28$ & $-559778,5$ & LT B-C1 & C & OJ (stray find) \\
\hline 107 & Prostějov-Čechovice & 'Úzké' & $-1134159,04$ & $-561383,83$ & LT B2-C & C & SIDL (settlement) \\
\hline 108 & Prostějov-Čechůvky & 'Kopaniny' (sometimes also 'Zácestky') & $-1134619,73$ & $-554456,55$ & LT B-C1, late LT (LT C-D1) & $\mathrm{A} 2$ & SIDL (settlement) \\
\hline 109 & $\begin{array}{l}\text { Prostějov- } \\
\text {-Domamyslice }\end{array}$ & built-up area, Dr. Řehulka garden & $-1134274,68$ & $-562047,53$ & LT B-C1 & c & OJ (stray find) \\
\hline 110 & Prostějov-Krasice & 'U hřbitova' & $-1134441,19$ & $-560505,56$ & $\begin{array}{l}\text { late LT (LT C-D) without } \\
\text { the evidence of LT D1 }\end{array}$ & B1 & OJ (stray find) \\
\hline 111 & Prostějov-Vrahovice & Čs. armádniho sboru street & $-1133780,44$ & $-555306,69$ & LT in general & $\mathrm{D}$ & STOPA (trace) \\
\hline 112 & Prostějovičky & 'Pod sádky' & $-1138058,65$ & $-567575,97$ & LT C2-D1 & $\mathrm{A} 1$ & OJ (stray find) \\
\hline 113 & Protivanov & to the southwest of the municipality & $-1131918,24$ & $-579887,07$ & LT D1 & A1 & DEPOT (hoard) \\
\hline 114 & Príkazy & 'Podsedky' & $-1115375,03$ & $-553391,56$ & LT B2-C & $\mathrm{C}$ & OJ (stray find) \\
\hline 115 & Přikazy & 'Muškáty' & $-1114854,33$ & $-553138,09$ & LT in general & D & OJ (stray find) \\
\hline 116 & Príkazy & 'Pižmáky' & $-1115154,33$ & $-553730,62$ & LT B and LTC & c & SIDL (settlement) \\
\hline 117 & Príkazy & 'Pod Dědinou' & $-1113730,87$ & $-553934,35$ & LT B and LTC & $\mathrm{C}$ & OJ (stray find) \\
\hline 118 & Ptení & 'Prajský žlíbek' & $-1125128,16$ & $-573817,59$ & LT C2-D1 & A1 & DEPOT (hoard) \\
\hline 119 & Ptení & 'Bernovy', location no. 1 & $-1126662,21$ & $-569181,74$ & LT C2-D1 & $\mathrm{A} 1$ & SIDL (settlement) \\
\hline 120 & Ptení & location no. 2 & $-1127021,52$ & $-569208,56$ & LT C2-D1 & $\mathrm{A} 1$ & SIDL (settlement) \\
\hline 121 & Ptení & 'Za mlýnem', location no. 3 & $-1127057,5$ & $-568877,3$ & LT C2-D1 & A1 & SIDL (settlement) \\
\hline 122 & Ptení & location no. 4 & $-1127879,23$ & $-569025,46$ & LT C2-D1 & $\mathrm{A} 1$ & SIDL (settlement) \\
\hline 123 & Ptení & 'Zeliska', location no. 5 & -1127366 & $-568713,71$ & LT B-C1, LT C2-D1 & A2 & SIDL (settlement) \\
\hline 124 & Ptení & 'V brezzi', location no. 6 & $-1128723,31$ & $-568557,68$ & LT C2-D1 & $\mathrm{A} 1$ & SIDL (settlement) \\
\hline 125 & Pustiměr̆ & airport & $-1152038,85$ & $-566585,93$ & LT in general & $\mathrm{D}$ & OJ (stray find) \\
\hline 126 & Pustiměr̆ & construction of the motorway & $-1149567,69$ & $-564745,8$ & LT in general & D & STOPA (trace) \\
\hline 127 & Pustiměr & 'Farské,' by the spring of the brook & $-1149127,82$ & $-565322,46$ & LT B1, LT C2, LT D1 & $\mathrm{A} 2$ & SIDL (settlement) \\
\hline 128 & Rozvadovice & $\begin{array}{l}\text { to the east of the road towards Litovel, } \\
\text { in the vicinity of spot height } 229,6\end{array}$ & $-1110603,45$ & $-557847,19$ & $\begin{array}{l}\text { LT B-C1, LT C-D without } \\
\text { the evidence of LT D1 }\end{array}$ & B2 & SIDL (settlement) \\
\hline 129 & Rychtářov & 'Hajšupa' & $-1147061,93$ & $-573412,25$ & LT C2-D1 & $\mathrm{A} 1$ & SIDL (settlement) \\
\hline 130 & Seloutky & 'Na zápních' & $-1136661,95$ & $-559603,11$ & $\begin{array}{l}\text { LT C2-D1 } \\
\text { (according to literature) }\end{array}$ & D & SIDL (settlement) \\
\hline 131 & Seloutky & 'Záhumeni', 'U Planičky' & $-1136808,89$ & $-562679,27$ & $\begin{array}{l}\text { LT B-C1, LT C-D without } \\
\text { the evidence of LT D1 }\end{array}$ & B2 & SIDL (settlement) \\
\hline 132 & Seloutky & 'Rozumky' & $-1136234,33$ & $-562771,08$ & LT in general & D & STOPA (trace) \\
\hline 133 & Senička & 'Na Záhumeni' & $-1115420,92$ & $-560687,96$ & LT in general & D & SIDL (settlement) \\
\hline 134 & Skrbeň & 'Hradisko' & $-1115057,88$ & $-552281,17$ & LT A, LT B-C & c & SIDL (settlement) \\
\hline 135 & Slatinice & 'Nad vinohrádky' & $-1123799,99$ & $-559406,75$ & LT C2-D1 & A1 & STOPA (trace) \\
\hline 136 & Slatinice & 'Padělky', 'Trávníky' & $-1123801,84$ & $-557603,08$ & LT C2-D1 & $\mathrm{A} 1$ & SIDL (settlement) \\
\hline 137 & Slatinky & 'Vinohrádky', 'Močilky' & $-1125440,26$ & $-559297,13$ & LT B-C1, LT C2-D1 & A2 & SIDL (settlement) \\
\hline 138 & Slatinky & 'U dubů' & $-1124773,04$ & $-559257,72$ & LT A, LT B-C & C & STOPA (trace) \\
\hline 139 & Služín & 'Za pastouškou', 'Široké' & $-1125683,65$ & $-563667,32$ & LT A, LT C2-D1 & $\mathrm{A} 1$ & SIDL (settlement) \\
\hline 140 & Služín & 'Trávník' & $-1126228,39$ & $-562755,29$ & LT C-D & B1 & STOPA (trace) \\
\hline 141 & Smržice & 'Šimanov', 'Stráž', 'Vlčí doly' & $-1129707,26$ & $-556992,33$ & LT A, LT B-C1 & $\mathrm{C}$ & SIDL (settlement) \\
\hline 142 & Smržice & 'Rybnik' & $-1131974,32$ & $-557995,42$ & $\begin{array}{l}\text { LT B-C1, LT B-C, LT C-D, } \\
\text { LT C2-D1 }\end{array}$ & A2 & SIDL (settlement) \\
\hline 143 & Smržice & 'Trávniky u ostrova', by the third waterworks & $-1131212,21$ & $-558584,06$ & LT B-D1 & A2 & SIDL (settlement) \\
\hline 144 & Stařechovice & 'Rodky' & $-1127900,55$ & $-560678,31$ & LT B-C1 & $\mathrm{C}$ & SIDL (settlement) \\
\hline 145 & Stařechovice & 'Záhumenky' & $-1126696,26$ & $-562225,81$ & LT B-C & $\mathrm{C}$ & SIDL (settlement) \\
\hline 146 & Stichovice & villa by the reservoir & $-1133337,35$ & $-564260,72$ & $\begin{array}{l}\text { LT C2-D1 } \\
\text { (rotary quern - now lost) }\end{array}$ & A1 & SIDL (settlement) \\
\hline 147 & Stínava & 'Ježův hrad' & $-1131913,76$ & $-570405,02$ & LT A, LT B-C, LT C2 & $\mathrm{B} 1$ & SIDL (settlement) \\
\hline 148 & Studenec & 'Nad skalami' & $-1128234,33$ & $-558130,17$ & $\begin{array}{l}\text { LT B-C, late LT (LT C2) } \\
\text { without the evidence of LTD1 }\end{array}$ & c & SIDL (settlement) \\
\hline 149 & Tážaly & built-up area & $-1127943,81$ & $-547577,2$ & LT B-C & $\mathrm{C}$ & SIDL (settlement) \\
\hline 150 & Topolany & 'Za pastviskem' & $-1120044,07$ & $-552189,39$ & $\mathrm{LT}$ in general & D & SIDL (settlement) \\
\hline 151 & Topolany & 'Střední dily u Topolan' & $-1121237,87$ & $-552386,24$ & LT B-C & $\mathrm{C}$ & SIDL (settlement) \\
\hline 152 & Tovačov & 'Hrad'ouch' & $-1138207,26$ & $-546281,97$ & LT B-C1, LT B-C & c & SIDL (settlement) \\
\hline 153 & Třebčín & 'Familiantsko' & $-1124887,58$ & $-557185,75$ & LT C, LT C2-D1 (rotary quern) & A2 & SIDL (settlement) \\
\hline
\end{tabular}




\begin{tabular}{|c|c|c|c|c|c|c|c|}
\hline ID & Cadastre & Location & Y-JTSK & X-JTSK & Dating & \begin{tabular}{|l|} 
Code of \\
the site \\
for the \\
analysis \\
\end{tabular} & Type of the evidence \\
\hline 154 & Třebčín & 'Spodní díly' & $-1126377,18$ & $-556561,33$ & LT B-C1 & C & SIDL (settlement) \\
\hline 155 & Tvorovice & 'Panské' & $-1146024,78$ & $-551398,53$ & LT in general & D & SIDL (settlement) \\
\hline 156 & Tvorovice & 'Pololáni' & $-1145690,01$ & $-550885,32$ & LT B-C & c & SIDL (settlement) \\
\hline 157 & Unčovice & 'Záhony' & $-1112721,7$ & $-556228,77$ & LT C2-D1 & $\mathrm{A} 1$ & SIDL (settlement) \\
\hline 158 & Určice & 'Dubská' & $-1138449,95$ & $-560902,65$ & LT B-C1, LT C2-D1 & A2 & SIDL (settlement) \\
\hline 159 & Určice & 'Hrubý Bořecký' & $-1138486,26$ & $-559263,07$ & LT B-C & $\mathrm{C}$ & SIDL (settlement) \\
\hline 160 & Určice & built-up area & $-1138416,15$ & $-561728,99$ & $\begin{array}{l}\text { LT C-D, late LT (LT C2) } \\
\text { without the evidence } \\
\text { of LT D1 }\end{array}$ & B2 & SIDL (settlement) \\
\hline 161 & Určice & 'Kumberky' & $-1138322,22$ & $-562337,53$ & LT A, LT & D & STOPA (trace) \\
\hline 162 & Určice & 'Téniska' & $-1137565,51$ & $-562199,95$ & LT A, LT in general & $\mathrm{D}$ & SIDL (settlement) \\
\hline 163 & Vítonice & 'Nad Boží mukou' & $-1135675,68$ & $-552931,7$ & LT B-C1 & $\mathrm{C}$ & SIDL (settlement) \\
\hline 164 & Vítonice & 'Okroužky', 'Padělky' & $-1136009,05$ & $-553270,37$ & LT B-C & C & SIDL (settlement) \\
\hline 165 & Vranovice & ‘Háj' & $-1141299,53$ & $-561923,07$ & LT A, LT B-C & C & SIDL (settlement) \\
\hline 166 & Vřesovice & 'Klenperk' & $-1141286,73$ & $-556856,76$ & LT B-C & $\mathrm{C}$ & SIDL (settlement) \\
\hline 167 & Vyškov & $\begin{array}{l}\text { 'Legérní pole', right bank of the Marchanický } \\
\text { brook }\end{array}$ & $-1152370,48$ & $-567833,89$ & LT A, LT B-C1, LT C2-D1 & A2 & SIDL (settlement) \\
\hline 168 & Výšovice & 'Padělek' & $-1140468,84$ & $-557701,52$ & LTC & $\mathrm{C}$ & SIDL (settlement) \\
\hline 169 & Žárovice & 'Poddubi' & $-1133610,69$ & $-568092,08$ & LT A, LT B-C1, LT C2-D1 & $\mathrm{A} 2$ & SIDL (settlement) \\
\hline 170 & Žešov & 'Záblati' & $-1138318,09$ & $-558428,95$ & $\begin{array}{l}\text { LT B-C1, LT B-C, late LT } \\
\text { without the evidence of LT D1 }\end{array}$ & B2 & SIDL (settlement) \\
\hline
\end{tabular}

\section{Bibliography}

Andrałojć, M. - Andrałojć, M. 2012:

Mennictwo celtyckie na Kujawach / Celtic coinage in the Kujawy region. Poznań.

Artioli et al. 2020:

Artioli, G. - Canovaro, C. - Nimis, P. - Angelini, I.:

LIA of Prehistoric Metals in the Central Mediterranean Area: A Review. Archaeometry 62, 53-85.

https://doi.org/10.1111/arcm.12542

Barral, P. - Nouvel, P. 2012:

La dynamique d'urbanisation à la fin de l'âge du Fer dans le centre est de la France. In: Sievers, S. - Schönfelder, M. /eds./: Die Frage der Protourbanisation in der Eisenzeit / La question de la proto urbanisation à lâge du Fer. Akten des 34. internationalen Kolloquiums der AFEAF vom 13.-16. Mai 2010 in Aschaffenburg. Kolloquien zur Vor- und Frühgeschichte 16. Bonn, 139-164.

Bockius, R. 1991:

Fremdimpulse am Ende der Latènezeit im Rhein-Main-Moselgebiet. In: Haffner, A. - Miron, A. /eds./: Studien zur Eisenzeit im Hunsrück-Nahe-Raum. Trier, 281-294.

Böhm, J. 1937:

Staré Hradisko III. Ročenka Národopisného a průmyslového musea města Prostějova a Hané XIV, 5-36.

Božič, D. 1993:

Slovenija in srednja Evropa v poznolatenskem obdobju. Arheološki vestnik 44, 137-152.

Božič, D. 1998:

Neues über die Kontakte längs der Bernsteinstraße während der Spätlatènezeit. Arheološki vestnik 49, 141-156.

Břen̆, J. 1964:

Význam spon pro datování keltských oppid v Čechách. Sborník Národního muzea v Praze XVIII, řada A - Historie, č. 5, 195-289.

Byrska-Fudali, M. - Przybyła, M. M. - Rudnicki, M. 2009:

Celtic coins found at site 2 in Modlniczka, dist. Cracow. Sprawozdania Archeologiczne 61, 273-295.

Castelin, K. 1965:

Keltský statér z Ptení. Numismatické listy 20, 129-135.
Čambal, R. 2019:

Osídlenie juhozápadného Slovenska v strednej a neskorej době laténskej a problematika jeho záveru. In: Kovár, B. - Ruttkay, M. /eds./: Kolaps očami archeológie. Nitra, 115-135.

Čambal et al. 2015:

Čambal, R. - Bazovský, I. - Budaj, M. - Kovár, B.:

Boische Besiedlung im Oppidum von Bratislava und in seinem Hinterland. In: Karwowski, M. - Salač, V. - Sievers, S. /eds./: Boier zwischen Realität und Fiktion. Akten des internationalen Kolloquiums in Český Krumlov vom 14.-16. 11. 2013. Bonn, 225-242.

Čižmár̆, I. 2006:

Ptení. Osídlení mikroregionu v době laténské. Manuscript of a bachleor's thesis, Faculty of Arts, Masaryk University, Brno.

Čižmár̆, I. 2008:

Zázemí oppida Staré Hradisko. Manuscript of a master's thesis, Faculty of Arts, Masaryk University, Brno.

Čižmár̆, I. 2012a:

Pozdně laténská chata z Dětkovic (okr. Prostějov). Acta Musei Moraviae, Scientiae sociales XCVII, 85-100.

Čižmár̆ I. 2012b:

Železný depot z Přílep. In: Březinová, G. - Varsik, Vl. /eds./: Archeológia na prahu histórie. K životnému jubileu Karola Pietu. Nitra, 137-143.

Čižmár̆, I. 2015:

Pozdně laténská chata z Ohrozimi, okr. Prostějov. Archeologické rozhledy $67,438-463$.

Čižmár̆, I. 2018:

Vývoj laténského osídlení na střední Moravě v období změny centrálních sídel. Manuscript of a Ph.D. dissertation, Faculty of Philosophy and Science, Silesian University, Opava.

Čižmár̆, I. - Čižmář, M. - Režný, M. 2015:

Archeologický průzkum lokality Hajšupa u Rychtářova, okr. Vyškov. Pravěk Nová řada 23, 149-171.

Čižmár̆, I. - Hlubek, L. 2016:

Sídliště z doby laténské v Unčovicích (okr. Olomouc). Acta Musei Moraviae, Scientiae sociales CI, 29-46. 
Čižmář, I. - Popelka, M. 2020:

Pozdně laténské žárové hroby ze Seče (okr. Prostějov). Příspěvek $\mathrm{k}$ pohřebnímu ritu pozdní doby laténské na Moravě. In: Čižmář, I. - Čižmářová, H. - Humpolová, A. /eds./: Jantarová stezka v proměnách času. Brno, 203-212.

Čižmár̆, M. 1970:

Zur relativ-chronologischen Stellung des jüngsten Horizontes keltischer Gräberfelder in Mähren. Archeologické rozhledy 22, 569-573.

Čižmár̆, M. 1973:

Keltská „Viereckschanze“ u Ludéřova, okr. Olomouc. Archeologické rozhledy $25,77-81$.

Čižmár̆, M. 1984:

Laténské sídliště z Velkých Hostěrádek, okr. Břeclav. Památky archeologické 75, 463-485.

Čižmár̆, M. 1987:

Laténské sídliště ze Strachotína, okr. Břeclav. Památky archeologické 78, 205-230.

Čižmár̆, M. 1990:

Zur Stellung von Kotouč in der späten Latènezeit. Acta Archaeologica Carpathica XXIX, 147-161.

Čižmář, M. 1992:

Nástin vývoje osídlení Břeclavska v době laténské. XXI. Mikulovské sympozium 1991. Brno, 71-79.

Čižmář, M. 1993:

Zur Chronologie der Púchover Kultur in Mähren. Památky archeologické 84, 86-96.

Čižmár̆, M. 1994:

Pozdně laténské sídliště v Dolních Břežanech (okres Praha-západ). Archeologické rozhledy 46, 594-606.

Čižmář, M. 1995:

Značky na dnech laténské keramiky na Moravě II. Acta Musei Moraviae, Scientiae sociales LXXX, 109-120.

Čižmár̆, M. 1996:

Neue Erkenntnisse über die Spätlatènezeit in Mähren. In: Urban, O. H. - Jerem, E. - Krenn-Leeb, A. - Neugebauer, J.-W. /eds./: Die Kelten in den Alpen und an der Donau. Budapest - Wien, 359-369.

Čižmár̆, M. 2002a:

Keltské oppidum Staré Hradisko. Archeologické památky stř̌ední Moravy 4. Olomouc.

Čižmár̆, M. 2002b:

Laténský depot ze Ptení. K poznání kontaktů našeho území $\mathrm{s}$ jihem. Památky archeologické 93, 194-225.

Čižmár̆, M. 2002c:

Ökonomische Struktur des Oppidums Staré Hradisko. In: Dobiat, C. - Sievers, S. - Stöllner, T. /eds./: Dürrnberg und Manching. Wirtschaftsarchäologie im ostkeltischen Raum. Kolloquien zur Vor- und Frühgeschichte 7. Bonn, 297-313.

Čižmár̆, M. 2003:

Laténské sídliště v Bořitově. Pravěk, Supplementum 10. Brno.

Čižmár̆, M. - Čižmářová, J. - Kejzlar, M. 2011:

Detektorová prospekce archeologických lokalit na Moravě v roce 2010. Přehled výzkumů 52-2, 86-95.

Čižmářr, M. - Čižmářová, J. - Meduna, J. 2018:

Němčice a Staré Hradisko. Spony / Němčice und Staré Hradisko. Fibeln. Brno.

Čižmár̆, M. - Kolníková, E. 2006

Němčice - obchodní a industriální centrum doby laténské na Moravě. Archeologické rozhledy 58, 261-283.

Čižmář, M. - Kolníková, E. - Noeske, H. Ch. 2008:

Němčice-Víceměřice - ein neues Handels- und Industriezentrum der Latènezeit in Mähren. Germania 86, 655-700.
Čižmár̆, M. - Leichmann, J. 2002:

Laténské žernovy ze Starého Hradiska. Památky archeologické 93, 259-271.

Čižmár̆, M. - Leichmann, J. 2007:

Pozdně laténské žernovy na Moravě. Památky archeologické 98, 109-128.

Čižmář, M. - Meduna, J. 1985:

Bodenzeichen auf latènezeitlicher Keramik in Mähren. Památky archeologické 76, 78-100.

Čižmářr, M. - Meduna, J. 2012:

„Bójské“ spony v Čechách a na Moravě. Archeologické rozhledy 64, 347-356.

Čižmár̆, M. - Salaš, M. 2009:

Nové hradiště v Moravské bráně. Archeologické rozhledy 61, 63-76.

Čižmář, Z. - Hlava, M. - Šmíd, M. 2005:

Laténská hrnčiŕšká pec $z$ Ptení (okr. Prostějov). Pravěk Nová řada 13 (2003), 279-293.

Čižmářová, J. 1996:

Bernstein aus dem keltischen Oppidum Staré Hradisko in Mähren. Arheološki vestnik 47, 173-182.

Čižmářová, J. 2004:

Encyklopedie Keltů na Moravě a ve Slezsku. Praha.

Čižmářová, J. 2005:

Keltské pohřebiště v Brně-Maloměřicích. Pravěk, Supplementum 14. Brno.

Dąbrowska, T. 1988:

Wczesne fazy kultury przeworskiej. Chronologia - zasięg - powiązania. Warszawa.

Danielisová, A. 2010:

Oppidum České Lhotice a jeho sídelní zázemí. Archeologické studijní materiály 17. Pardubice.

Danielisová, A. 2014:

Staré Hradisko - pohled na urbanismus doby laténské optikou moravského oppida. In: Čižmářová, J. - Venclová, N. - Březinová, G. /eds./: Moravské křižovatky. Střední Podunají mezi pravěkem a historií. Brno, 315-334.

Danielisová, A. 2015:

The 'Boii' and Moravia - the same but different. In: Karwowski, M. - Salač, V. - Sievers, S. /eds./: Boier zwischen Realität und Fiktion. Akten des internationalen Kolloquiums in Český Krumlov vom 14.-16. 11. 2013. Bonn, 177-190.

Danielisová, A. 2020:

Bohemia at the End of the La Tène Period: Objects, Materials, Chronology, and Main Development Trends - A Review. Památky archeologické 111, 113-157.

Danielisová et al. 2018:

Danielisová, A. - Kysela, J. - Mangel, T. - Kyselý, R. - Militký, J.: Iron Age site in Žehuň, Central Bohemia. An open settlement with central functions. Památky archeologické 109, 127-178.

Danielisová et al. 2021:

Danielisová, A. - Pajdla, P. - Bursák, D. - Strnad, L. - Trubač, J. - Kmošek. J.:

Claiming the land or protecting the goods? The Duchcov hoard in Bohemia as a proxy for 'Celtic migrations' in Europe in the $4^{\text {th }}$ century BCE. Journal of Archaeological Science 127, 105314. https://doi.org/10.1016/j.jas.2020.105314

Danielisová et al. in print:

Danielisová, A. - Bursák, D. - Strnad, L. - Trubač, J.:

Life Cycles of Metals in the lron Age $\left(4^{\text {th }}-1^{\text {st }}\right.$ Century BC). Sourcing and Recycling of Copper Based Alloys. In: Török, B. /ed./: Proceedings of the $5^{\text {th }}$ International conference Archeometallurgy 
in Europe, Miskolc (HU), 19. - 21. 5. 2019. Monographies lnstrumentum.

Danielisová, A. - Mangel, T. - Drnovský, V. 2011:

Kamenné rotační mlýny a jejich význam v době laténské. Živá archeologie 12/2011, 67-71.

Danielisová, A. - Militký, J. 2014:

Pozdně laténské spony $z$ oppida Třísov, získané povrchovou prospekcí v letech 2008-2013. Archeologické rozhledy 66, 40-66.

Danielisová, A. - Štekerová, K. 2015:

Sociální simulace při zkoumání společnosti, ekonomiky a využívání krajiny v době železné: metoda a př́klady. Památky archeologické 106, 137-180.

Deberge, Y. - Kurzaj, M.-C. - Lauranson, R. 2019:

Les agglomérations ouvertes de la fin de l'âge du Fer en territoires arverne et vellave (nord-est du Massif central). In: Fichtl, S. Barral, P. - Pierrevelcin, G. - Schönfelder M. /eds./: Les agglomérations ouvertes de l'Europe celtique (III ${ }^{\mathrm{e}} \mathrm{I}^{\mathrm{er}} \mathrm{S}$. av. J.-C.). Mémoires d'Archéologie du Grand Est 4. Strasbourg, 175-212.

Demetz, S. 1999:

Fibeln der Spätlatène- und frühen römischen Kaiserzeit in den Alpenländern. Rahden/Westfalen.

Drda, P. - Rybová, A. 1998:

Keltové a Čechy. Praha.

Droberjar, E. 2014:

Poznámky ke studiu o nejstarší germánské keramice v Čechách a na Moravě. Zborník slovenského národného múzea CVIII, Archeológia 24, 253-259.

Droberjar, E. 2019:

Wpływy kultury przeworskiej w Czechach i na Morawach od okresu późnolateńskiego po wczesną fazę okresu wędrówek ludów. In: Kot-Legieć, K. - Michałowski, A. - Olędzki, M. - Piotrowska, M. /eds./: Kultura przeworska. Procesy przemian i kontakty zewnętrzne. Łódź, 251-290.

Dulęba, P. 2009:

Przemiany kulturowe w Zachodniej Małopolsce w okresie od III do I wieku przed Chr. Przyczynek do kontaktów mi dzy Celtami a Germanami. In: Karwowski, M. - Droberjar, E. /eds./: Archeologia Barbarzyńców 2008: powiązania i kontakty w świecie barbarzyńskim. Materiały z IV Protohistorycznej Konferencji Sanok, 13-17 października 2008. Rzeszów, 11-35.

Dulęba, P. - Wysocki, P. 2017:

A new discovery of a Celtic coin hoard from western Lesser Poland. Archäologisches Korrespondenzblatt 47, 51-66.

Dymowski, A. - Rudnicki, R. 2012:

Kujawskie znaleziska monet antycznych. Nowe źródła do dziejów pieniądza na ziemiach Polski w starożytności. Buletyn Numizmatyczny 4 (368), 241-258.

Egger, M. 1984:

Keltische Münzfunde aus Manching III. Jahrbuch für Numismatik und Geldgeschichte 34, 135-161.

Fojtík, P. 2018:

Doloplazy (okr. Prostějov). Přehled výzkumů 59-1, 189-190.

Frána et al. 1995:

Frána, J. - Jiráň, L. - Maštalka, A. - Moucha, V.:

Artifacts of copper and copper alloys in prehistoric Bohemia from the viewpoint of analyses of element composition I. Památky archeologické, Supplementum 3. Praha.

Frána et al. 1997:

Frána, J. - Jirán̆, L. - Moucha, V. - Sankot, P.:

Artifacts of copper and copper alloys in prehistoric Bohemia from the viewpoint of analyses of element composition II. Památky archeologické, Supplementum 8. Praha.
Gebhard, R. 1991:

Die Fibeln aus dem Oppidum von Manching. Die Ausgrabungen in Manching 14. Stuttgart.

Godtowski, K. 1978:

$\mathrm{Zu}$ Besiedlungsveränderungen in Schlesien und den Nachbarräumen während der jüngeren vorrömischen Eisenzeit. Beiträge zum Randbereich der Latènekultur 26, 107-133.

Godłowski, K. 1985:

Przemiany kulturowe i osadnicze w południowej i środkowej Polsce w młodszym okresie przedrzymskim i w okresie rzymskim. Prace komisji archeologicznej 23. Wrocław - Warszawa Kraków - Gdańsk - Łódź.

Gottwald, A. 1913:

Předhistorické nálezy z okolí Určic. Časopis Moravského musea zemského XIII, 281-293.

Gottwald, A. 1924:

Pravěká sídliště a pohřebiště na Prostějovsku. Prostějov.

Gottwald, A. 1931:

Můj archeologický výzkum. Prostějov.

Graff, Y. 1963:

„Oppida“ et „castella“ du pays des Belges. Celticum VI, 113-170. Guštin, M. 1977:

Relativna kronologija grobov „Mokronoške skupine“ — Relative chronology of graves of the Mokronog group'. In: Guštin, M. /ed./: Keltske študije. Posavski muzej Brešice 4. Brešice, 67-103.

Haevernick, Th. E. 1960:

Die Glasarmringe und Ringperlen der Mittel- und Spätlatènezeit auf dem europäischen Festland. Bonn.

Hiriart et al. 2020:

Hiriart, E. - Smělý, T. - Genechesi, J. - Gruel, K. - Nieto-Pelletier, S. - Wigg-Wolf, D.:

Coinages and economic practices between the $3^{\text {rd }}$ century and the beginning of the $2^{\text {nd }}$ century BC. In: Pierrevelcin, G. - Kysela, J. - Fichtl, St. /eds./: Unité et diversité du monde celtique. Actes du $42^{\mathrm{e}}$ colloque international de l'AFEAF, Prague, 10-13 mai 2018. Collection AFEAF 2. Paris, 181-212.

Hlava, M. 1997:

Využití tuhy v době laténské na Moravě. Manuscript of a master's thesis, Faculty of Arts, Masaryk University, Brno.

Hlava, M. 2000:

Časně laténský kolkovaný střep z Určic a nálezy „braubašské“ kolkované keramiky na Prostějovsku. Zpravodaj Muzea Prostějovska v Prostějově 1-2, 52-61.

Hlava, M. 2002a:

Laténské sídliště u Tvarožné (okr. Brno-venkov). Pokus o rekonstrukci výzkumu z roku 1943. Pravěk Nová řada 11 (2001), 301-354.

Hlava, M. 2002b:

Poznámky k laténskému hrobu z Kojetína, okr. Přerov. Archeologie Moravy a Slezska 2, 63-66.

Hlava, M. 2008:

Grafit v době laténské na Moravě. Památky archeologické 99, 189-258.

Hlava, M. 2015:

Laténský depot z Ptení (okr. Prostějov): nová fakta. Památky archeologické 106, 247-290.

Hlubek, L. 2010:

Malé Hradisko (okr. Prostějov). Přehled výzkumů 51, 368-369.

Hodson, F. R. 1968:

The La Tène Cemetery at Münsingen-Rain. Catalogue and Relative Chronology. Acta Bernensia 5. Bern. 
Horálková, P. 1993:

Pozdně laténské sídliště ve Vyškově s nálezy germánské keramiky. Archeologické rozhledy 45, 474-491, 541-542.

Jansová, L. 1964:

Svědectví keramiky o pobytu Bójů na jihozápadním Slovensku a přilehlém území. Študijné zvesti Archeologického ústavu SAV 13, 185-194.

\section{Kalábek, M. 1999:}

Dolany (okr. Olomouc). Přehled výzkumů 40 (1997-1998), 267268.

\section{Kalábek, M. 2006:}

Germánské osídlení Olomouce. In: Droberjar, E. - Lutovský, M. /eds./: Archeologie barbarů 2005. Sborník příspěvků z I. protohistorické konference „Pozdně keltské, germánské a časně slovanské osídlení“ (Kounice, 20.-22. září 2005). Praha, 431-450.

Karasová, Z. 2002:

Spony z keltského oppida na Třísově. Památky archeologické 93, 226-258.

\section{Karwowski, M. 2015:}

Die befestigten Höhensiedlungen in der „boischen“ Donauzone. In: Karwowski, M. - Salač, V. - Sievers, S. /eds./: Boier zwischen Realität und Fiktion. Akten des internationalen Kolloquiums in Český Krumlov vom 14.-16. 11. 2013. Bonn, 211-224.

Kellner, H.-J. 1990:

Die Münzfunde von Manching und die keltischen Fundmünzen aus Südbayern. Die Ausgrabungen in Manching 12. Stuttgart. Kolníková, E. 1998:

Keltské mince v peňažných dejinách Moravy. In: Štefan, J. T. Krejčík, T. /eds./: Peníze v proměnách času / Geld im Wandel der Zeit. Acta numismatica Bohemiae, Moraviae et Silesiae 2. Ostrava, 21-33.

Kolníková, E. 2007:

Nové nálezy mincí - príspevok k obrazu doby laténskej na Morave. Pravěk Nová řada 16 (2006), 437-462.

Kolníková, E. 2012:

Němčice. Ein Macht-, Industrie-, und Handelszentrums der Latènezeit in Mähren und Siedlungen am ihren Rande. Kommentierter Fundkatalog - Münzen. Brno.

Kolníková, E. - Černý, Z. 2006:

Nový typ keltských zlatých mincí - nález z Polkovic. Numismatické listy 61, 49-55.

Koutecký, D. - Venclová, N. 1979:

K problematice osídlení severozápadních Čech v době laténské a římské. Sídliště Počerady I a II. Památky archeologické 70, 42-112.

Krämer, W. 1962:

Manching II. Zu den Ausgrabungen in den Jahren 1957 bis 1961. Germania 40, 293-317.

\section{Krämer, W. 1985:}

Die Grabfunde von Manching und die latènezeitlichen Flachgräber in Südbayern. Die Ausgrabungen in Manching 9. Stuttgart.

Kysela, J. 2017:

SITOS - CHRÉMATA? CHALKOS - EIKONA? K řeckým mincím ve střední Evropě mladší doby železné. Numismatický sborník 30/2, 193-227.

Kysela, J. 2020:

Things and thoughts. Central Europe and the Mediterranean in the $4^{\text {th }}-1^{\text {st }}$ centuries BC. Praha.

Lipka, F. - Snětina, K. 1913:

Staré Hradisko. Gallské oppidum na Moravě. Časopis Moravského musea zemského XIII, 112-133.
Ludikouský, K. 1973:

Keltské sídliště v Rajhradě (okr. Brno-venkov). Přehled výzkumů 1972, 42-43.

Maciatowicz, A. 2015:

Handwerk, Handel und Heirat? Neues über Kontakte der Boier mit den Germanen anhand von Fibelfunden. In: Karwowski, M. - Salač, V. - Sievers, S. /eds./: Boier zwischen Realität und Fiktion. Akten des internationalen Kolloquiums in Český Krumlov vom 14.-16. 11. 2013. Bonn, 273-293.

Mangel, T. - Jošková, T. 2019:

East bohemian finds of belt segments with a central knob and side plates as evidence of interregional contacts during the La Tène Period. In: Beljak Pažinová, N. - Repka, D. /eds./: Sedem kruhov Jozefa Bujnu. Studia Historica Nitriensia 23, Supplementum. Nitra, 465-480.

DOI: $10.17846 /$ SHN.2019.23.S.465-480

Martínek et al. 2013:

Martínek, J. - Létal, A. - Peška, J. - Kalábek, M. - Vrána, J. Šlézar, P.:

Identifikace starých cest a dalších objektů za pomoci LLS. In: Gojda, M. - John, J. et al.: Archeologie a letecké laserové skenování krajiny. Plzeň, 228-240.

Márton, A. 2004:

La fibule du type de Mötschwil. Acta Archaeologica Academiae Scientiarum Hungariae 55, 279-322.

https://doi.org/10.1556/aarch.55.2004.3-4.3

Meduna, J. 1961:

Staré Hradisko. Katalog der Funde im Museum der Stadt Boskovice. Fontes Archaeologiae Moravicae II. Brno.

Meduna, J. 1968:

Příspěvek $\mathrm{k}$ problematice pozdní doby laténské na Moravě. Archeologické rozhledy 20, 56-69.

Meduna, J. 1970a:

Das keltische Oppidum Staré Hradisko in Mähren. Germania 48, 34-59.

Meduna, J. 1970b:

Staré Hradisko II. Katalog der Funde aus den Museen in Brno /Brünn/, Praha /Prag/, Olomouc, Plumlov und Prostějov. Fontes Archaeologiae Moravicae V. Brno.

Meduna, J. 1973:

Střep časně przeworské kultury z Rymic (okr. Kroměříž). Přehled výzkumů 1972, 48-49, 142.

Meduna, J. 1980a:

Die latènezetlichen Siedlungen in Mähren. Praha.

Meduna, J. 1980b:

Die latènezeitlichen Siedlungen und Gräberfelder in Mähren (Katalog). Fontes Archaeologiae Moravicae XI. Brno.

Meduna, J. 1996:

Das Depot von Ptení (Kr. Prostějov) und die Handelsbeziehungen Mährens während der Spätlatènezeit. In: Wozniak, Z. /ed./: Kontakte längs der Bernsteinstraße (zwischen Caput Adriae und den Ostseegebieten) in der Zeit um Christi Geburt. Kraków, 97-115.

Militký, J. 2008:

Mincovnictví v době laténské. In: Venclová, N. /ed./: Archeologie pravěkých Čech 7. Doba laténská. Praha, 122-128.

Militký, J. 2015:

Oppidum Hradiště u Stradonic. Komentovaný katalog mincovních nálezů a dokladů mincovní výroby. Praha.

Militký, J. 2018:

Keltské mincovnictví ve 3. a 2. století před Kristem v Čechách. Praha. 
Moore et al. 2013 :

Moore, T. - Braun, A. - Creighton, J. - Cripps, L. - Haupt, P. Klenner, I. - Nouvel, P. - Ponroy, C. - Schönfelder, M.:

Oppida, Agglomerations, and Suburbia: the Bibracte Environs and New Perspectives on Late Iron Age Urbanism in Central-Eastern France. European Journal of Archaeology 16 (3), 491-517.

https://doi.org/10.1179/1461957113Y.0000000034

Motyková, K. - Drda, P. - Rybová, A. 1990:

Oppidum Závist - prostor brány A v předsunutém šíjovém opevnění. Památky archeologické 81, 308-433.

Niederschlag et al. 2003:

Niederschlag, E. - Pernicka, E. - Seifert, Th. - Bartelheim, M.: The Determination of Lead Isotope Ratios by Multiple Collector Icp-Ms: A Case Study of Early Bronze Age Artefacts and their Possible Relation With Ore Deposits of the Erzgebirge. Archaeometry 45, 61-100.

https://doi.org/10.1111/1475-4754.00097

Nortmann, H. 1991:

Die eisenzeitlichen Burgwälle des Trierer Landes: In: Haffner, A. - Miron, A. /eds./: Studien zur Eisenzeit im Hunsrück-Nahe-Raum. Trier, 121-140.

Novotný, P. - Slobodník, M. 2003:

Staré dobývací práce u Malého hradiska na Drahanské vrchovině. Geologické výzkumy na Moravě a ve Slezsku 10, 52-55.

Ottaway, B. S. 1994:

Prähistorische Archäometallurgie. Espel-Kamp.

Parma, D. 2007:

Laténské sídliště Otrokovice „Chmelín“. Pravěk Nová řada 16 (2006), 325-358.

Pernicka, E. 2014:

Provenance Determination of Archaeological Metal Objects. In: Roberts B. W. - Thornton Ch. P. /eds. /: Archaeometallurgy in Global Perspective. Methods and Syntheses. New York, 239268. DOI: $10.1007 / 978-1-4614-9017-311$

Pernicka, E. 2017:

Provenance and recycling of ancient silver. A comment on "Iridium to provenance ancient silver" by Jonathan R. Wood, Michael F. Charlton, Mercedes Murillo-Barroso, Marcos Martinón-Torres. Journal of Archaeological Science 86, 123-126. https://doi.org/10.1016/j.jas.2017.07.004

Peška, J. 2020:

Monoxyl a další dřevěné struktury v oblasti řeky Moravy z lokalit Moravičanských jezer na katastru Mohelnice. Přehled výzkumů 61/1, 97-104.

Pieta, K. 1982 :

Die Púchov-Kultur. Nitra.

Pieta, K. 1997:

Die frühen norisch-pannonischen Handelsbeziehungen mit dem nördlichen Mitteldonaugebiet. Acta Musei Moraviae, Scientiae sociales LXXXII, Supplementum, 45-61.

Pieta, K. 2000:

Latènezeitlicher Burgwall und Opferplatz (?) in Trenčianské Teplice. In: Bouzek, J. - Friesinger, H. - Pieta, K. - Komoróczy, B. /eds./: Gentes, Reges und Rom. Brno, 129-153.

Pieta, K. 2008:

Keltské osídlenie Slovenska. Mladšia doba laténská. Nitra.

Pieta, K. 2019:

Early Roman Period Burials of Púchov Culture: Buried Natives or Offered Foreigners? Slovenská archeológia LXVII, 241-286. https://doi.org/10.31577/slovarch.2019.67.8

Polenz, H. 1971:

Mittel- und spätlatènezeitliche Brandgräber aus Dietzenbach,
Lankreis Offenbach am Main. Studien und Forschungen Neue Folge 4. Langen.

Poleska, P. 2006:

Celtycki mikroregion osadniczy w rejonie podkrakowskim. Kraków.

Poulová, L. 2011:

Situly s pásem kolkované výzdoby na podhrdlí z období plochých keltských pohřebišt na Prostějovsku. Manuscript of a master's thesis, Faculty of Arts, Masaryk University, Brno.

Přichystal, A. - Opravil, E. 1992:

Poznatky k přírodnímu prostředí keltského oppida Staré Hradisko. Acta Musei Moraviae, Scientiae sociales LXXVII, 115-121.

Radivojević et al. 2019:

Radivojević, M. - Roberts, B. W. - Pernicka, E. - Stos-Gale, Z. Martinón-Torres, M. - Rehren, T. - Bray, P. - Brandherm, D. Ling, J. - Mei, J. - Vankilde, H. - Kristiansen, K. - Shennan, S. J. - Broodbank, C.:

The Provenance, Use, and Circulation of Metals in the European Bronze Age: The State of Debate. Journal of Archaeological Research 27, 131-185.

https://doi.org/10.1007/s10814-018-9123-9

Radoměrský, P. 1955:

Nálezy keltských mincí v Čechách, na Moravě a ve Slezsku. In: Nohejlová-Prátová, E. /ed./: Nálezy mincí v Čechách, na Moravě a ve Slezsku I. Praha, 35-84.

Rogers, J. S. 2011:

Czech logboats: Early inland watercraft from Bohemia and Moravia. Sborník prací Filozofické fakulty brněnské univerzity $\mathrm{M}$ 16, 171-202.

Rudnicki, M. 2010:

Moneta celtycka z Kalisza-Piwonic a początki dziejów mennictwa na ziemiach Polski - Celtic coin from Kalisz-Piwonice and the beginnings of the history of coinage on Polish territory. In: Suchodolski, S. - Zawadzki, M. /eds./: Od Kalisii do Kalisza. Skarby doliny Prosny. Warszawa, 13-22.

Rudnicki, M. 2012a:

Pieniądz celtycki na Śląsku. In: Garbaczewski, W. - Macyra, R. /eds./: Pieniądz i banki na Sląsku. Studia nad Dziejami Pieniądza i Bankowości w Polsce. Poznań, 33-68.

Rudnicki, M. 2012b:

Nummi Lugiorum - statery typu krakowskiego. Wiadomości Numizmatyczne 56/1, 1-96.

Rudnicki, M. 2014:

Nowa Cerekwia - the Middle La Tène centre of power north of the Carpathians. In: Čižmářová, J. - Venclová, N. - Březinová, G. /eds./: Moravské křižovatky. Střední Podunají mezi pravěkem a historií. Brno, 421-437.

Rudnicki et al. 2009:

Rudnicki, M. - Miłek, S. - Ziabka, L. - Kędzierski, A.:

Mennica celtycka pod Kaliszem / Celtic mint near Kalisz, Poland. Wiadomości Numizmatyczne 53/2, 103-145.

Rulf, J. - Salač, V. 1995:

Zpráva o laténské keramice v severozápadních Čechách. Archeologické rozhledy 47, 373-417.

Rybová, A. 1969:

Keramika na rovinných osadách východních Čech v době laténské. Památky archeologické 60, 367-442.

Salač, V. 1993:

Severozápadní Čechy v posledních staletích starého letopočtu. Manuscript of a CSc. dissertation, Faculty of Arts, Charles University, Prague.

Sedlmayer, H. 2009:

Die fibeln von Magdalensberg. Funde der Grabungsjahre 1948-2002 und Altfunde des 19. Jahrhunderts. Archäologi- 
sche Forschungen zu den Grabungen auf dem Magdalensberg 16. Klagenfurt am Wörthersee.

Smrž, Z. 1994:

Vývoj osídlení v mikroregionu Lužického potoka na Kladensku (severozápadní Čechy) - část I. Archeologické rozhledy 46, 345-393.

Stöckli, W. E. 1974:

Bemerkungen zur räumlichen und zeitlichen Gruppierung der Funde im Oppidum Manching. Germania 52, 368-385.

Striewe, K. 1996:

Studien zur Nauheimer Fibel und ähnlichen Formen der Spätlatènezeit. Internationale Archeologie 29. Espelkamp.

Šimek, E. 1958:

Poslední Keltové na Moravě. Brno.

Šiška, D. 1996:

Nové poznatky o keltském osídlení Prostějovska (1973-1993). Předběžná zpráva. Pravěk Nová řada 3 (1995), 239-261.

Šrot, J. 1975:

Místopis archeologických tratí okresu Prostějov dle nálezů Červinkových, Gottwaldových, Dobešových, Všetičkových, Skutilových aj. Manuscript deposited in Museum and gallery in Prostějov / Muzeum a galerie v Prostějově.

Tappert, C. 2007:

Die eisenzeitliche Besiedlungsentwicklung im Stadtgebiet von Straubing (Niederbayern). In: Prammer, J. - Sandner, S. - Tappert, C. /eds./: Siedlungsdynamik und Gesellschaft. Beiträge des internationalen Kolloquiums zur keltischen Besiedlungsgeschichte im bayerischen Donauraum, Österreich und der Tschechischen Republik. Straubing, 173-206.

Tejral, J. 1968:

K otázce postavení Moravy kolem přelomu letopočtu. Památky archeologické 59, 488-518.

Valentová, J. 2013:

Oppidum Stradonice. Keramika ze starších fondů Národního muzea. Praha.

Valentová, J. - Šumberová, R. 2007:

Nová laténská sídliště v Podoubraví, okr. Kutná Hora. Pravěk Nová řada 16 (2006), 267-308.

Venclová, N. 1998:

Mšecké Žehrovice in Bohemia. Archaeological Background to a Celtic Hero $3^{\text {rd }}-2^{\text {nd }}$ cent. B.C. Sceaux.

Venclová, N. 2001:

Výroba a sídla v době laténské. Projekt Loděnice. Praha.

Venclová, N. /ed./ 2008:

Archeologie pravěkých Čech 7. Doba laténská. Praha.

Venclová, N. /ed./ 2013:

Prehistory of Bohemia 6. The Late Iron Age - the La Tène Period. Praha.
Venclová, N. 2016:

Němčice and Staré Hradisko. Iron Age glass and glass-working in central Europe. Praha.

Vich, D. 2005:

Laténské nálezy na českomoravském pomezí. Pravěk Nová řada 13 (2003), 309-350.

Vich, D. 2017:

Doba laténská v severní části Boskovické brázdy ve světle drobných kovových nálezů. Archeologické rozhledy 69, 629-671.

Völling, T. 1995:

Studien zu Fibelformen der jüngeren vorrömischen Eisenzeit und ältesten römischen Kaiserzeit. Berichte der Römisch-Germanischen Komission 75 (1994), 147-282.

Völling, T. 2005:

Germanien an der Zeitenwende. Studien zum Kulturwandel beim Übergang von der vorrömischen Eisenzeit zur älteren römischen Kaiserzeit in der Germania Magna. BAR International Series 1360.

Vrána, J. 2014:

Archeologický výzkum reliktů úvozových cest v rámci projektu „Výzkum historických cest v oblasti severozápadní Moravy a východních Čech“. In: Martínek, J. /ed./: Výzkum historických cest v interdisciplinárním kontextu II. Brno, 13-19.

Vrtel, A. 2012:

Keltské oppidum v Bratislave. In: Šedivý, J. - Štefanovičová, T. /eds./: Dejiny Bratislavy 1. Od počiatkov do prelomu 12. a 13. storočia. Bratislava, 164-179.

Waldhauser, J. 1984:

Les fortifications celtiques de la période L.T. C-D1 en Bohême. Oppida et castella. In: Cahen-Delhaye, A. - Duval, A. - Leman-Delerive, G. - Leman, P. /eds./: Les Celtes en Belgique et dans le Nord de la France. Les Fortifications de l'Âge du Fer. Revue du Nord, $\mathrm{n}^{\circ}$ spécial hors série. Lille, 265-270.

Waldhauser, J. 1993:

Siedlung Radovesice (23) und ein Modell des „keltischen Dorfes" in Böhmen. In: Waldhauser, J. und Arbeitsgruppe: Die hallstatt- und latènezeitliche Siedlung mit Gräberfeld bei Radovesice in Böhmen, I.-II. Archeologický výzkum v severních Čechách 21. Praha, 264-457.

Waldhauser, J. 2001:

Encyklopedie Keltů v Čechách. Praha.

Werner, J. 1955:

Die Nauheimer Fiebel. Jahrbuch des Römisch-Germanischen Zentralmuseums Mainz 2, 170-195.

Ženožičková, I. 2011:

Jemná keramika z keltského oppida Staré Hradisko. Manuscript of a master's thesis, Faculty of Arts, Masaryk University, Brno.

Ženožičková, I. - Nohálová, H. - Vaněček, Z. 2016:

Pozdně laténské sídlištní objekty z Hněvotína (okr. Olomouc). Pravěk Nová řada 24, 213-252.

Mgr. Ivan Čižmář, Ph.D., Institute for Archaeological Heritage (Ústav archeologické památkové péče Brno, v. v. i.), Kaloudova 1321/30, 61400 Brno, Czech Republic;

e-mail: cizmar@uapp.cz

Mgr. Alžběta Danielisová, Ph.D., Institute of Archaeology of the Czech Academy of Sciences, Prague (Archeologický ústav AV ČR, Praha, v. v. i.), Letenská 4, 11801 Praha 1, Czech Republic;

e-mail: danielisova@arup.cas.cz 